Prepared in cooperation with the New Jersey Department of Environmental Protection

\title{
Trends in the Quality of Water in New Jersey Streams, Water Years 1998-2007
}

Scientific Investigations Report 2010-5088 



\section{Trends in the Quality of Water in New Jersey Streams, Water Years 1998-2007}

By R. Edward Hickman and Bonnie J. Gray

Prepared in cooperation with the

New Jersey Department of Environmental Protection

Scientific Investigations Report 2010-5088 


\title{
U.S. Department of the Interior \\ KEN SALAZAR, Secretary \\ U.S. Geological Survey \\ Marcia K. McNutt, Director
}

\section{U.S. Geological Survey, Reston, Virginia: 2010}

\author{
For more information on the USGS — the Federal source for science about the Earth, its natural and living resources, \\ natural hazards, and the environment, visit http://www.usgs.gov or call 1-888-ASK-USGS \\ For an overview of USGS information products, including maps, imagery, and publications, \\ visit http://www.usgs.gov/pubprod \\ To order this and other USGS information products, visit http://store.usgs.gov
}

\begin{abstract}
Any use of trade, product, or firm names is for descriptive purposes only and does not imply endorsement by the U.S. Government.

Although this report is in the public domain, permission must be secured from the individual copyright owners to reproduce any copyrighted materials contained within this report.
\end{abstract}

Suggested citation:

Hickman, R. E., and Gray, B.J., 2010, Trends in the quality of water in New Jersey streams, water years 1998-2007: U.S. Geological Survey Scientific Investigations Report 2010-5088, 70 p. 


\section{Contents}

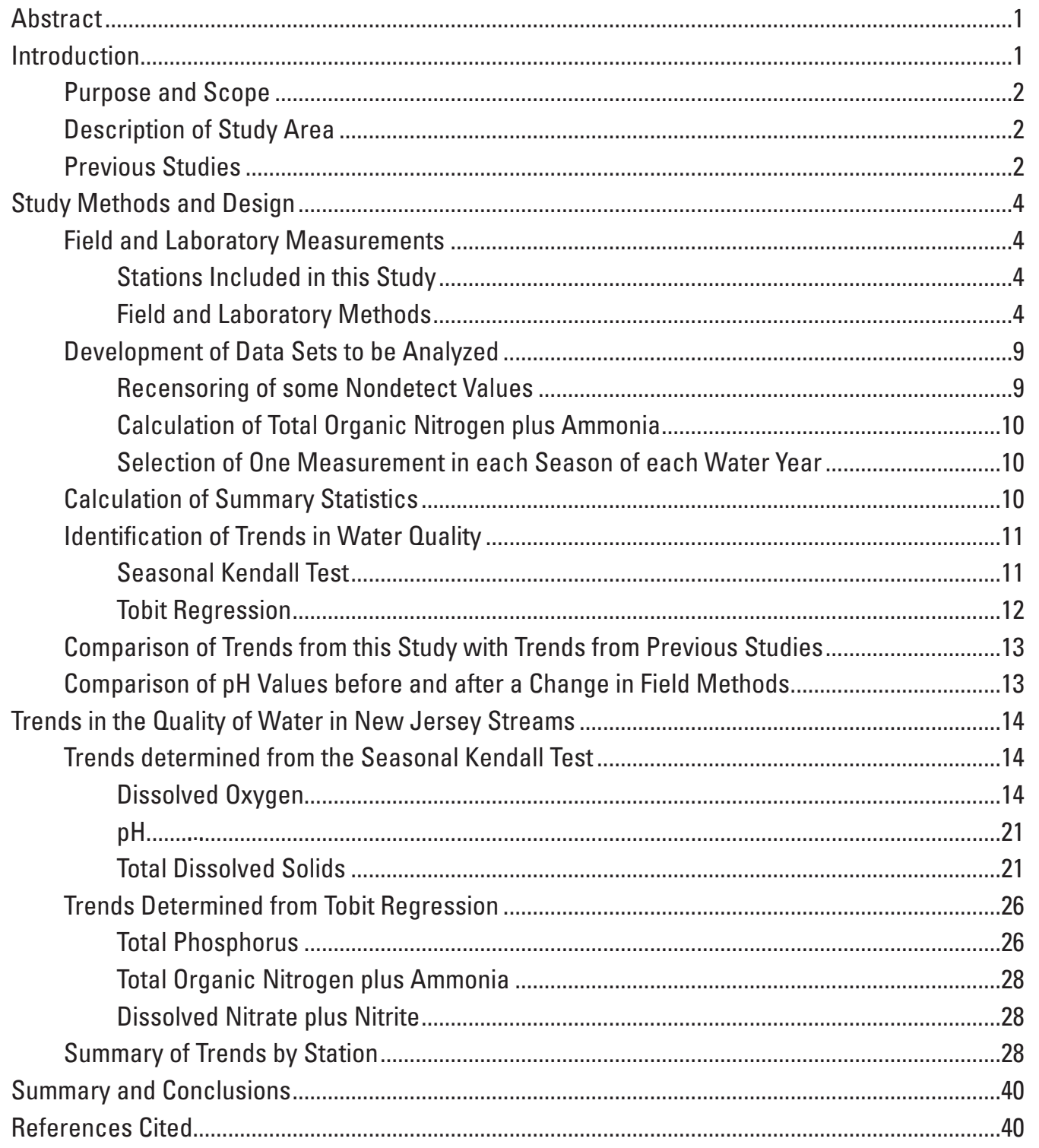




\section{Figures}

1-2. Map showing -

1. Land use and the Fall Line in New Jersey... .3

2. Locations of water-quality stations and New Jersey Department of Environmental Protection water regions in New Jersey.....

3. Plots showing results of the Seasonal Kendall trend test for concentrations of total dissolved solids at the water-quality station on the Whippany River near Pine Brook, N.J. (01381900), water years 1998-2007, $(A)$ concentrations as a function of streamflow, $(B)$ flow-adjusted concentrations and trend slope as a function of date, and $(C)$ concentrations and trend slope as a function of date.

4. Maps showing trends in $(A)$ year-round concentrations of dissolved oxygen and $(B)$ growing-season concentrations of dissolved oxygen at water-quality stations on streams in New Jersey, water years 1998-2007...

5-6. Plot showing-

5. Values of $\mathrm{pH}$ and dissolved oxygen measured continually at the waterquality station on the Delaware River at Trenton, N.J. (01463500), September 5-7, 2005 .

6. Growing-season concentrations of dissolved oxygen and times of measurement as a function of date at the water-quality station on Flat Brook near Flatbrookville, N.J. (01440000), water years 1998-2007.

7. Bar chart showing fraction of water-quality stations on streams in New Jersey with trends in year-round flow-adjusted concentrations of dissolved oxygen during water years 1980-86, 1986-95, and 1998-2007.....

8. Map showing trends in $\mathrm{pH}$ at water-quality stations on streams in New Jersey, water years 1998-2007.

9. Bar chart showing fraction of water-quality stations on streams in New Jersey with trends in flow-adjusted values of $\mathrm{pH}$ during water years 1980-86, 1986-95, and 1998-2007

10. Map showing trends in concentrations of total dissolved solids at water-quality stations on streams in New Jersey, water years 1998-2007...

11. Bar chart showing fraction of water-quality stations with trends in flow-adjusted concentrations of dissolved solids during water years 1980-86, 1986-95, and 1998-2007.

12. Plots showing results of trend analysis with Tobit regression for total organic nitrogen plus ammonia at the water-quality station on the Pequannock River at the Macopin Intake Dam, N.J. (01382500), water years 1998-2007, (A) measured concentrations as a function of predicted concentrations and $(B)$ measured and predicted concentrations and trend slope as a function of date.

13. Map showing trends in concentrations of total phosphorus at water-quality stations on streams in New Jersey, water years 1998-2007...

14. Bar chart showing fraction of water-quality stations with trends in flow-adjusted concentrations of total phosphorus during water years 1986-95 and 1998-2007.

15. Map showing trends in concentrations of total organic nitrogen plus ammonia at water-quality stations on streams in New Jersey, water years 1998-2007.

16. Bar chart showing fraction of water-quality stations with trends in flow-adjusted concentrations of organic nitrogen compounds during water years 1980-86, 1986-95, and 1998-2007 
17. Map showing trends in concentrations of dissolved nitrate plus nitrite at water-quality stations on streams in New Jersey, water years 1998-2007

18. Bar chart showing fraction of water-quality stations with trends in flow-adjusted concentrations of nitrate compounds during water years 1986-95 and 1998-2007 35

\section{Tables}

1. Water-quality stations included in this study of trends in the quality of water in New Jersey streams, water years 1998-2007.

2. References for methods of laboratory analyses of selected water-quality characteristics measured by the Ambient Surface-Water Quality Monitoring Network, New Jersey, water years 1998-2007.

3. Water-quality characteristics included in the study of water years 1998-2007 and in previous studies of trends of the quality of New Jersey streams.

4. Summary statistics for dissolved oxygen at water-quality stations on New Jersey streams, water years 1998-2007

5. Results of trend tests on-

5a. Results of trend tests on year-round flow-adjusted concentrations of dissolved oxygen at water-quality stations on New Jersey streams, water years 1998-2007.

5b. Results of trend tests on growing-season flow-adjusted concentrations of dissolved oxygen at water-quality stations on New Jersey streams, water years 1998-2007.

5c. Results of trend tests on flow-adjusted concentrations of year-round and growing-season dissolved oxygen at selected water-quality stations on New Jersey streams, water years 1998-2007

6. Summary statistics for $\mathrm{pH}$ at water-quality stations on New Jersey streams, water years 1998-2007

7. Results of trend tests on flow-adjusted values of $\mathrm{pH}$ at water-quality stations on New Jersey streams, water years 1998-2007

8. Summary statistics for total dissolved solids at water-quality stations on New Jersey streams, water years 1998-2007

9. Results of trend tests on flow-adjusted concentrations of total dissolved solids at water-quality stations on New Jersey streams, water years 1998-2007.

10. Summary statistics for total phosphorus at water-quality stations on New Jersey streams, water years 1998-2007

11. Results of trend tests on flow-adjusted concentrations of total phosphorus at waterquality stations on New Jersey streams, water years 1998-2007...

12. Summary statistics for total organic nitrogen plus ammonia at water-quality stations on New Jersey streams, water years 1998-2007.

13. Results of trend tests on flow-adjusted concentrations of total organic nitrogen plus ammonia at water-quality stations on New Jersey streams, water years 1998-2007.

14. Summary statistics for dissolved nitrate plus nitrite at water-quality stations on New Jersey streams, water years 1998-2007 
15. Results of trend tests on flow-adjusted concentrations of dissolved nitrate plus nitrite at water-quality stations on New Jersey streams, water years 1998-2007.

16. Results of trend tests on flow-adjusted concentrations of dissolved oxygen during water years 1998-2007 and earlier periods at selected water-quality stations on New Jersey streams..

17. Results of trend tests on flow-adjusted values of $\mathrm{pH}$ during water years 1998-2007 and earlier periods at selected water-quality stations on New Jersey streams

18. Results of trend tests on flow-adjusted concentrations of dissolved solids during water years 1998-2007 and earlier periods at selected water-quality stations on New Jersey streams...

19. Results of trend tests on flow-adjusted concentrations of total phosphorus during water years 1998-2007 and water years 1986-1995 at selected water-quality stations on New Jersey streams

20. Results of trend tests on flow-adjusted concentrations of organic nitrogen compounds during water years 1998-2007 and earlier periods at selected waterquality stations on New Jersey streams

21. Results of trend tests on flow-adjusted concentrations of nitrate compounds during water years 1998-2007 and water years 1986-1995 at selected water-quality stations on New Jersey streams

22. Results of trend tests on flow-adjusted values of six water-quality characteristics at water-quality stations on New Jersey streams, water years 1998-2007.

\section{Conversion Factors and Datums}

\begin{tabular}{lcl}
\multicolumn{1}{c}{ Multiply } & By & \multicolumn{1}{c}{ To obtain } \\
\hline & Area & \\
\hline square mile $\left(\mathrm{mi}^{2}\right)$ & 259.0 & hectare $($ ha $)$ \\
square mile $\left(\mathrm{mi}^{2}\right)$ & 2.590 & square kilometer $\left(\mathrm{km}^{2}\right)$ \\
\hline & Flow rate & \\
\hline cubic foot per second $\left(\mathrm{ft}^{3} / \mathrm{s}\right)$ & 0.02832 & cubic meter per second $\left(\mathrm{m}^{3} / \mathrm{s}\right)$ \\
\hline
\end{tabular}

Horizontal coordinates of water-quality stations are referenced to North American Datum of 1927 (NAD 27) or to the North American Datum of 1983 (NAD 83). Maps are referenced to the North American Datum of 1983.

Elevation, as used in this report, refers to distance above a vertical datum.

Concentrations of chemical constituents in water are given in milligrams per liter (mg/L). 


\title{
Trends in the Quality of Water in New Jersey Streams, Water Years 1998-2007
}

\author{
By R. Edward Hickman and Bonnie J. Gray
}

\section{Abstract}

Trends were determined in flow-adjusted values of selected water-quality characteristics measured year-round during water years 1998-2007 (October 1, 1997, through September 30,2007 ) at 70 stations on New Jersey streams. Water-quality characteristics included in the analysis are dissolved oxygen, $\mathrm{pH}$, total dissolved solids, total phosphorus, total organic nitrogen plus ammonia, and dissolved nitrate plus nitrite. In addition, trend tests also were conducted on measurements of dissolved oxygen made only during the growing season, April to September. Nearly all the water-quality data analyzed were collected by the New Jersey Department of Environmental Protection and the U.S. Geological Survey as part of the New Jersey Department of Environmental Protection Ambient Surface-Water Quality Monitoring Network.

Monotonic trends in flow-adjusted values of water quality were determined by use of procedures in the ESTREND computer program. A 0.05 level of significance was selected to indicate a trend. Results of tests were not reported if there were an insufficient number of measurements or insufficient number of detected concentrations, or if the results of the tests were affected by a change in data-collection methods.

Trends in values of dissolved oxygen, $\mathrm{pH}$, and total dissolved solids were identified using the Seasonal Kendall test. Trends or no trends in year-round concentrations of dissolved oxygen were determined for 66 stations; decreases at 4 stations and increases at 0 stations were identified. Trends or no trends in growing-season concentrations of dissolved oxygen were determined for 65 stations; decreases at 4 stations and increases at 4 stations were identified. Tests of $\mathrm{pH}$ values determined trends or no trends at 26 stations; decreases at 2 stations and increases at 3 stations were identified. Trends or no trends in total dissolved solids were reported for all 70 stations; decreases at 0 stations and increases at 24 stations were identified.

Trends in total phosphorus, total organic nitrogen plus ammonia, and dissolved nitrate plus nitrite were identified by use of Tobit regression. Two sets of trend tests were conducted - one set with all measurements and a second set with all measurements except the most extreme outlier if one could be identified. The result of the test with all measurements is reported if the results of the two tests are equivalent. The result of the test without the outlier is reported if the results of the two tests are not equivalent.

Trends or no trends in total phosphorus were determined for 69 stations. Decreases at 12 stations and increases at 5 stations were identified. Of the five stations on the Delaware River included in this study, decreases in concentration were identified at four.

Trends or no trends in total organic nitrogen plus ammonia were determined for 69 stations. Decreases and increases in concentrations were identified at six and nine stations, respectively.

Trends or no trends in dissolved nitrate plus nitrite were determined for 66 stations. Decreases and increases in concentration were identified at 4 and 19 stations, respectively.

\section{Introduction}

The Ambient Surface Water-Quality Monitoring Network (ASWQMN) program has been operated by the New Jersey Department of Environmental Protection (NJDEP) in cooperation with the U.S. Geological Survey (USGS) since 1985. Under this program, water-quality samples have been collected from streams at stations throughout the State and analyzed for water-quality characteristics. Of particular interest to the NJDEP is the quality of streams that either drain areas of targeted land-use types or are located in the downstream portions of each NJDEP water region. A total of 119 stations on nontidal streams are sampled as part of the ASWQMN; as many as 115 are sampled in any given water year (October 1 to September 30, numbered for the year in which it ends). Sampled stations include 4 on the Delaware River main stem, 7 background stations located in areas largely unaffected by human activity, and 23 watershed integrator stations with relatively large drainage basins that contain multiple land uses. There are also 43 land-use-indicator stations; the drainage basin of each is composed mostly of a single type of land use. 
Fifteen of these stations are designated as undeveloped, 9 as agricultural, 13 as urban, and 6 as mixed land uses. In addition, 42 statewide-status stations are chosen randomly every 2 years.

Each ASWGMN station is sampled four times a water year, once in each of the following periods: November to December, February to March, May to June, and August to September. Physical characteristics and concentrations of filtered and unfiltered nutrients, filtered organic carbon, and total dissolved solids are determined on samples of the water column. Unfiltered water samples are analyzed for recoverable trace elements at selected sites during February to March and August to September. Filtered samples of the water column collected during May and June are analyzed for pesticides, and bed-sediment samples collected during low-flow conditions during August and September are analyzed for nutrients and trace elements at these selected sites. These data were published annually for water years 1998 to 2005 in USGS reports titled "Water Resources Data-New Jersey." The data for the 2006 and 2007 water years are now available on the World Wide Web and can be accessed at http://wdrwater.usgs.gov/.

The USGS, in cooperation with the NJDEP, conducted a study to determine whether there have been monotonic trends in the water quality of the streams of New Jersey. The period of study is water years 1998-2007 (October 1, 1997 through September 30, 2007). A monotonic trend is an underlying change in one direction (either an increase or a decrease) in the value of a variable over the period of study; this change may occur during a short time or throughout the period of study.

Water-quality data for 70 stations were analyzed. The data analyzed were collected almost entirely by the ASWQMN. The following water-quality characteristics were selected for trend analysis by the NJDEP, in cooperation with the USGS: dissolved oxygen, $\mathrm{pH}$, total dissolved solids, total phosphorus, total organic nitrogen plus ammonia, and dissolved nitrate plus nitrite. Year-round measurements of each characteristic and those of dissolved oxygen made only during the growing season, April to September, were analyzed for trends.

The approach was to use procedures in the ESTREND computer program (Schertz and others, 1991) to identify monotonic trends in flow-adjusted values of each waterquality characteristic at each station. Flow-adjusted values are values of water quality which have been modified to remove some of the variation in water quality due to the variation in streamflow.

\section{Purpose and Scope}

This report presents the results of an analysis to identify monotonic trends in selected water-quality characteristics at stations on New Jersey streams at which a sufficient number of measurements of water quality were made during water years
1998-2007. Summary statistics of the values of each waterquality characteristic at each station, and results of trend tests in flow-adjusted values, are presented in figures and tables. Results of trend tests are compared to results from previous studies of trends in the quality of New Jersey streams. Results are not reported if they were affected by changes in the methods of collection.

\section{Description of Study Area}

New Jersey is geologically divided into northern and southern regions by the Fall Line (fig. 1) which is marked by a series of waterfalls along river courses (Watt, 2000). The land to the north of the Fall Line is underlain by sedimentary and crystalline bedrock, is higher in elevation, and varies more in elevation than land to the south. The land to the south is underlain by gravel, sand, silt, and clay.

Land use varies considerably throughout New Jersey (fig. 1). Much of the urban land lies close to the Fall Line, around New York City in the northeastern part of the State, and along the Atlantic Coast. Agricultural land tends to be present in the western half of the State, and forest is concentrated in the northwest and southeast.

\section{Previous Studies}

Two previous studies reported on trends in the water quality measured for the ASWQMN in streams throughout New Jersey. Both studies used the procedures in ESTREND (Schertz and others, 1991) to identify trends in water-quality values unadjusted for streamflow and in flow-adjusted values of water quality.

The first report by Hay and Campbell (1990) identified changes in water-quality characteristics during two periods of record-water years 1976-86 and water years 1980-86. Trends tests were conducted on values of 48 water-quality characteristics measured at 86 water-quality stations. Results were not reported if more than a few percent of the measurements were nondetects. Trends were identified at a 0.1 level of significance.

The second report by Hickman and Barringer (1999) identified changes in water-quality characteristics during water years 1986-95. Trends tests were conducted on 24 waterquality characteristics measured at 83 water-quality stations. Trends were identified at a 0.05 level of significance.

In addition, Sprague and others (2009) reported trends in total phosphorus, total nitrogen, and nitrate at 20 stations on streams in New Jersey as part of their study of selected stations across the United States during the period 1993-2003. Trends in flow-adjusted concentrations and in concentrations not adjusted for flow were estimated with a parametric multiple-regression analysis by use of the program LOADEST (Runkel and others, 2004). 


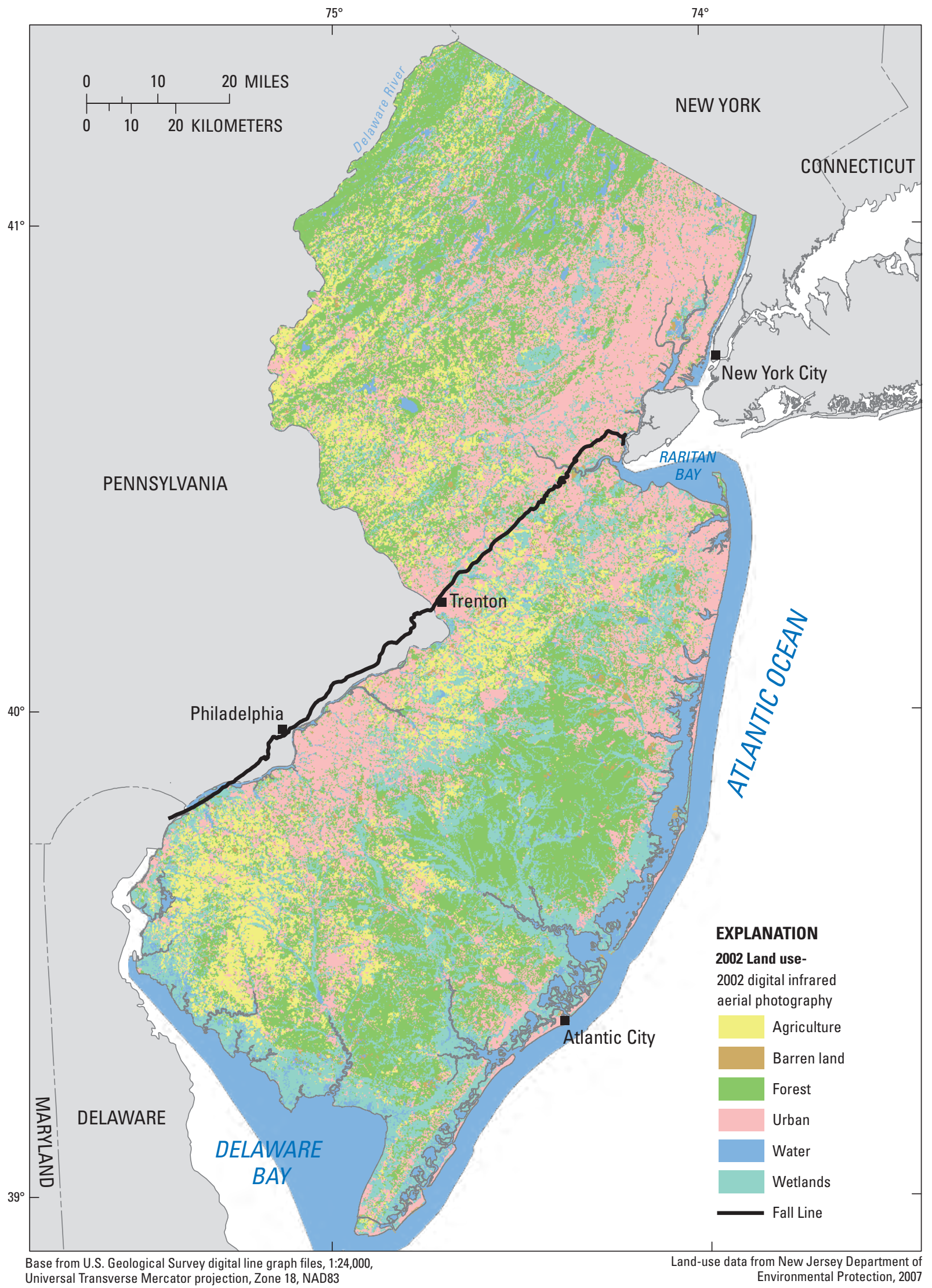

Figure 1. Land use and the Fall Line in New Jersey. 


\section{Study Methods and Design}

Water-quality data discussed in this report were retrieved from the USGS National Water Information System (NWIS) computer database (described in Mathey, 1998) and are available to the public at the USGS NWIS Web site (http://waterdata.usgs.gov/nj/nwis/qw/). These data also have been published in data reports for water years 1998 to 2005 (Deluca and others, 1999-2006); reports for water years 2002 to 2005 can be found (as "pdf" files) at the Web site http://pubs.usgs.gov/wdr/\#NJ .

Site data sheets containing the water-quality data for each station during water years 2006 and 2007 are available at the Web site http://wdr.water.usgs.gov/ as "pdf" files. Each site data sheet contains the water-quality data for one station for one water year.

\section{Field and Laboratory Measurements}

Field measurements and sample collection at each station were conducted by personnel of either the USGS or the NJDEP. The agency that collected information at each station is listed in table 1.

\section{Stations Included in this Study}

The 70 water-quality stations included in this study are listed in table 1 and shown in figure 2. In this report, the waterquality stations in tables are grouped by the five NJDEP water regions (New Jersey Department of Environmental Protection, 1997, fig. 2), and maps include the water regions so that the reader can easily locate the stations. All stations, but one, were sampled as part of the ASWQMN and were selected because there have been sufficient water-quality measurements for trend analysis (see below).

The one station not in the network, the Delaware River at Trenton, N.J. (01463500), was included to provide a more complete understanding of trends of the main stem Delaware River (table 1; fig. 2). This station was sampled by the USGS either (1) as part of the USGS National Water-Quality Assessment (NAWQA) Program or (2) in cooperation with the Delaware River Basin Commission.

These stations (table 1; fig. 2) are characterized by 15 or more measurements of water quality, 1 or more measurements in the first 2 water years of the period of study, and 1 or more measurements in the last 2 water years. Also, there is a value of instantaneous streamflow associated with each of these water-quality measurements. These characterizations approximate the data requirements necessary for running trend tests in ESTREND.

The stations can be divided on the basis of the size of the drainage basins. The drainage basins of most stations used in the study range from 1.07 to 762 square miles and lie entirely within New Jersey or within New Jersey and adjacent parts of southern New York (fig. 2; table 1). Five stations have drainage basins that range in size from 3,480 to 6,780 square miles. These stations are on the main stem Delaware River, and their basins include large areas of New York and Pennsylvania.

\section{Field and Laboratory Methods}

Field methods are described in the USGS National Field Manual (U.S. Geological Survey, variously dated). At each station, a composite sample of streamwater was collected at multiple points across the stream using either an open bottle or DH-81 sampler when wading, or an open bottle, D-95, or DH-95 sampler when sampling from a bridge. This composite sample was then split into subsamples using either a churn or cone splitter. Subsamples to be analyzed for total dissolved solids and dissolved nitrate plus nitrite were filtered.

The methods used to measure dissolved oxygen concentration at ASWQMN stations differed between the two agencies. The USGS reported the median of measurements at five or more points across the stream; measurements were made with an YSI model 58 water-quality meter until the beginning of water year 2002 and an YSI 600 QS water-quality meter during the rest of the period of study. The NJDEP reported the concentration at the centroid of streamflow; measurements were made with an YSI model 58 throughout the period of study.

The methods used as part of the ASWQMN to measure $\mathrm{pH}$ during the period of study also differed between the two agencies; in addition, the USGS changed its methods during the beginning of water year 2002. Through water year 2001, the USGS measured $\mathrm{pH}$ from a subsample of the composite using an Orion PerpHect Ross Combination $\mathrm{pH}$ Electrode with an epoxy body. Starting at the beginning of water year 2002, the USGS reported the median of $\mathrm{pH}$ measured at five or more points across the stream with a YSI 600 QS meter (during water years 2002-07). Throughout the period of study, the NJDEP measured $\mathrm{pH}$ from a subsample of the composite with a Beckman Coulter low-maintenance, gel-filled combination electrode.

Field methods used by the USGS to measure dissolved oxygen and $\mathrm{pH}$ at the station on the Delaware River at Trenton, N.J. (01463500), were different than those used at ASWQMN stations. Values of dissolved oxygen and $\mathrm{pH}$ were measured with an YSI 6820 or YSI 6920 meter at about 12 points across the river; the reported value of each water-quality characteristic is the median of the measured values.

Concentrations of total dissolved solids, total phosphorus, total organic nitrogen plus ammonia, and dissolved nitrate plus nitrite were determined in subsamples sent to USGS laboratories in either Lakewood, Colorado, or Ocala, Florida; methods of analysis are listed in table 2. Methods for determining concentrations of total phosphorus and total organic nitrogen plus ammonia changed during the period of study. For total phosphorus, the Kjeldahl sample digestion was replaced with a persulfate digestion. Three methods of determination were used for total organic nitrogen plus ammonia, the last of which 


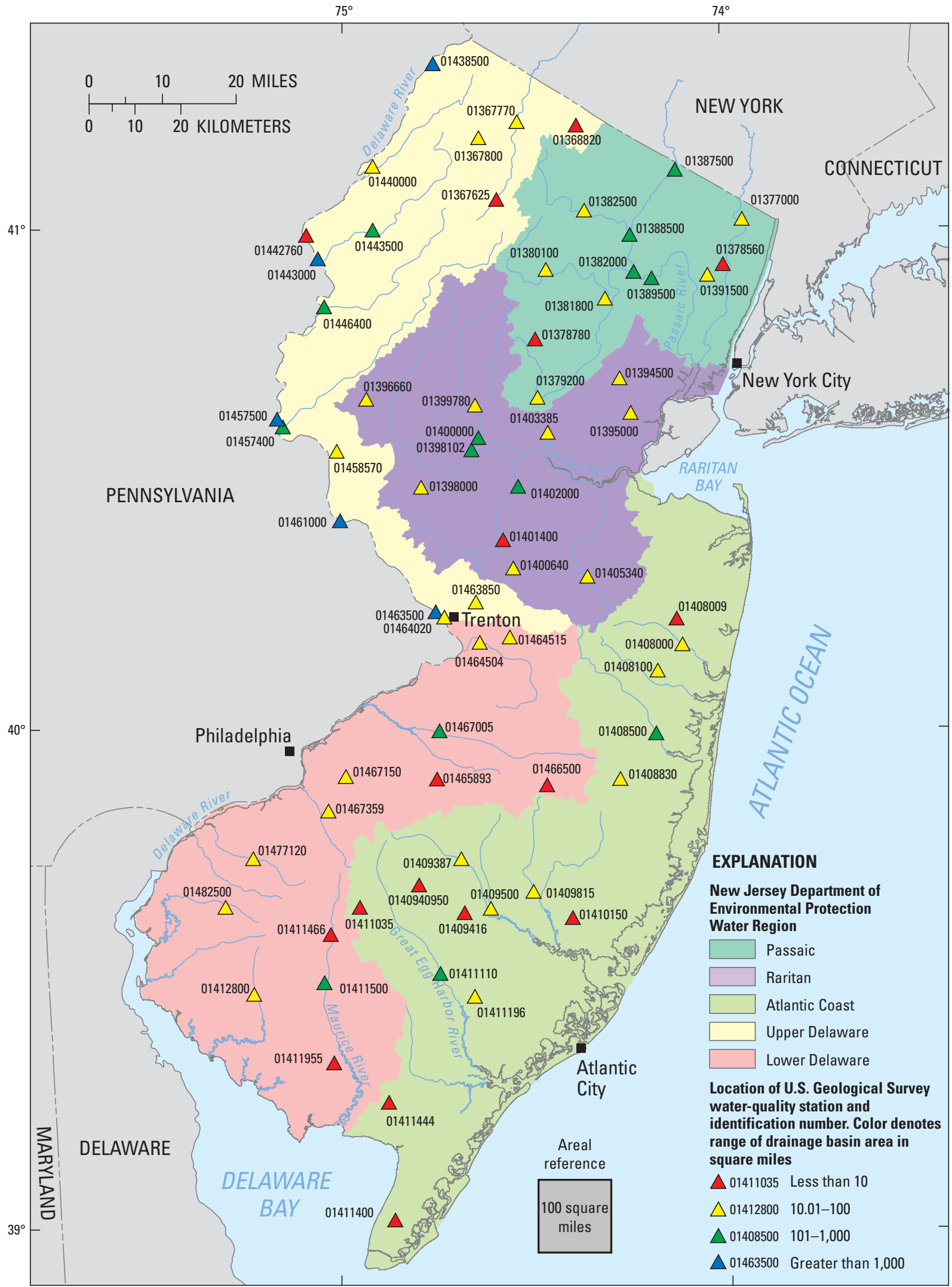

Base from U.S. Geological Survey digital line graph files, 1:24,000,

Universal Transverse Mercator projection, Zone 18, NAD83

Figure 2. Locations of water-quality stations and New Jersey Department of Environmental Protection water regions in New Jersey. 


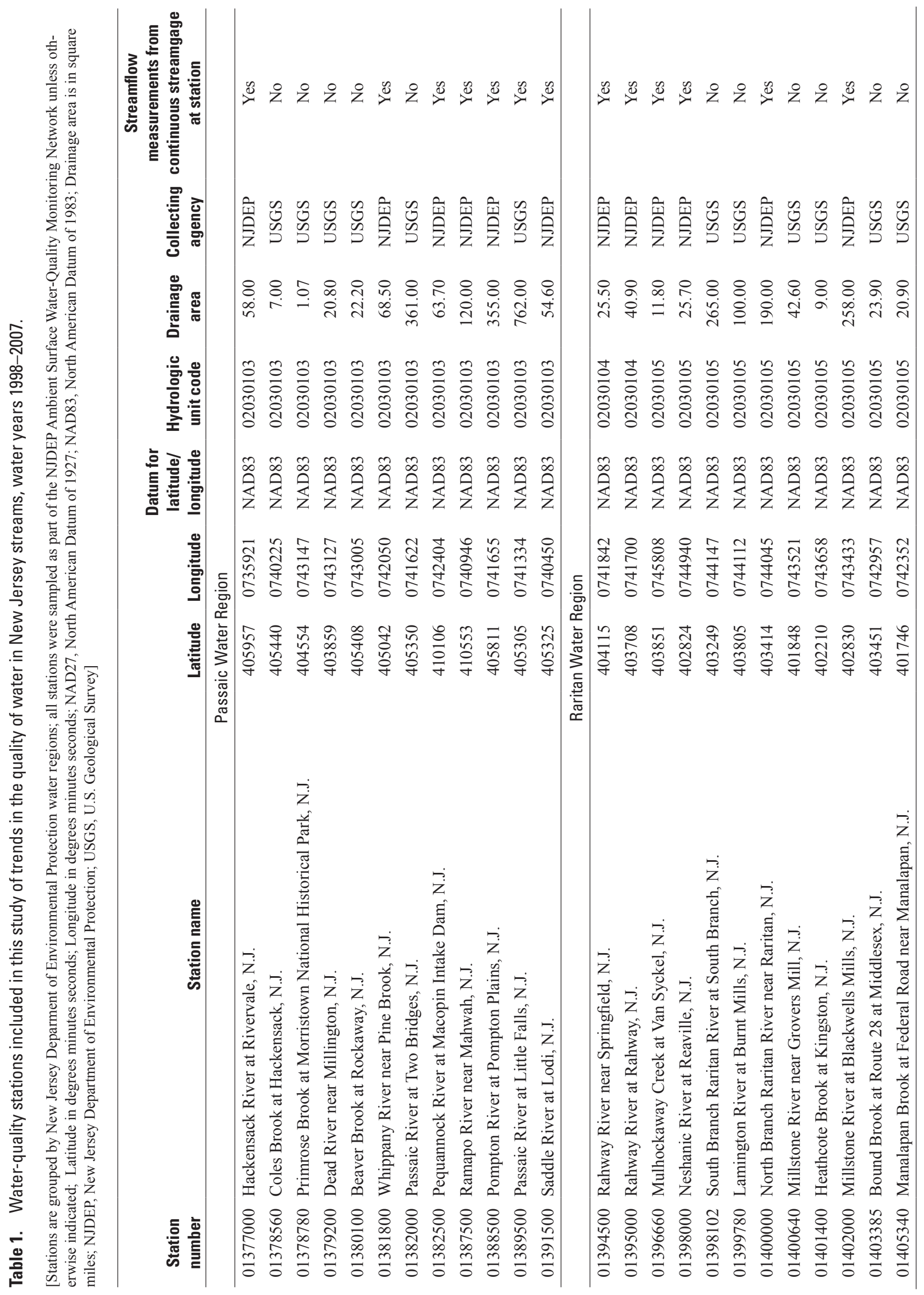


Study Methods and Design

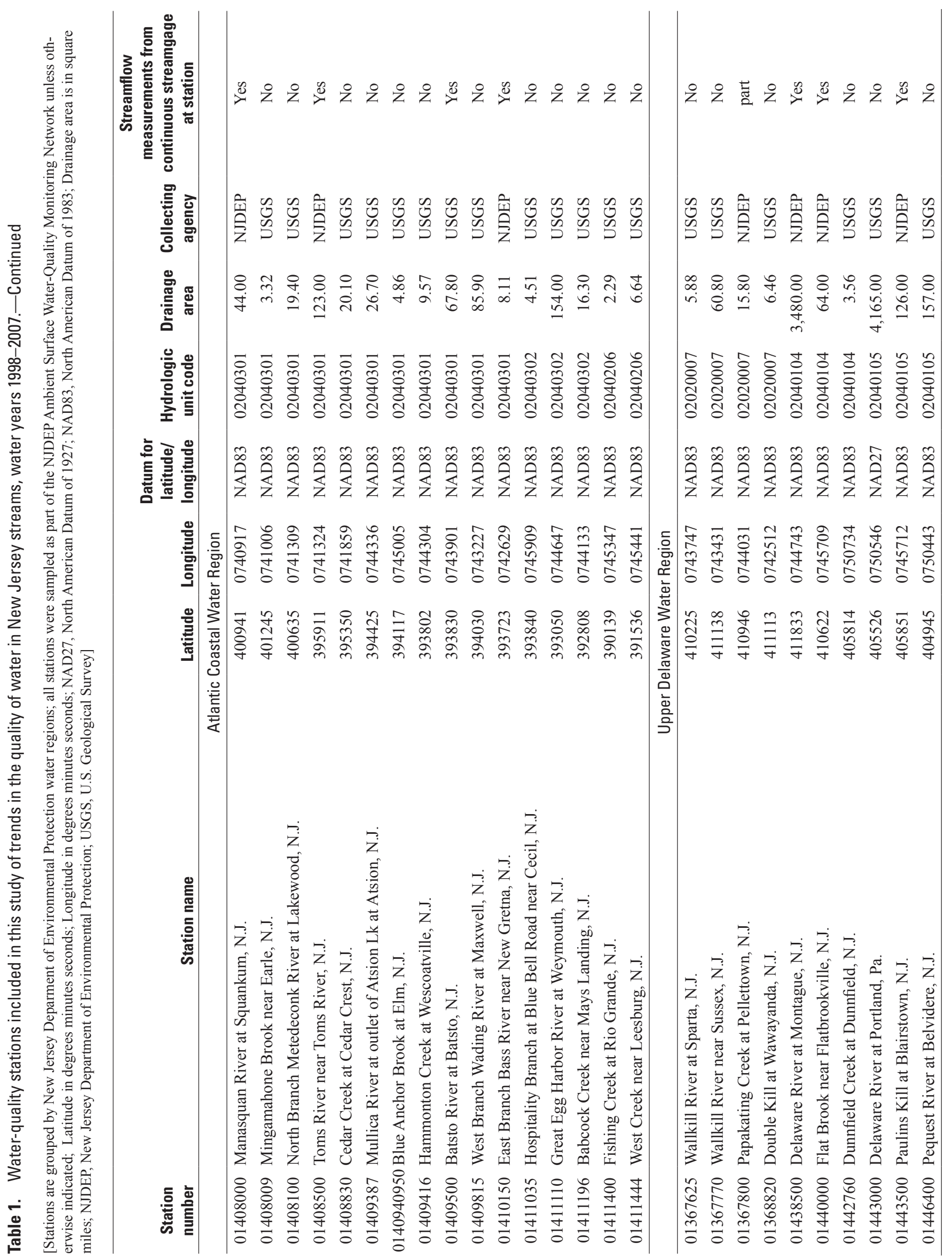




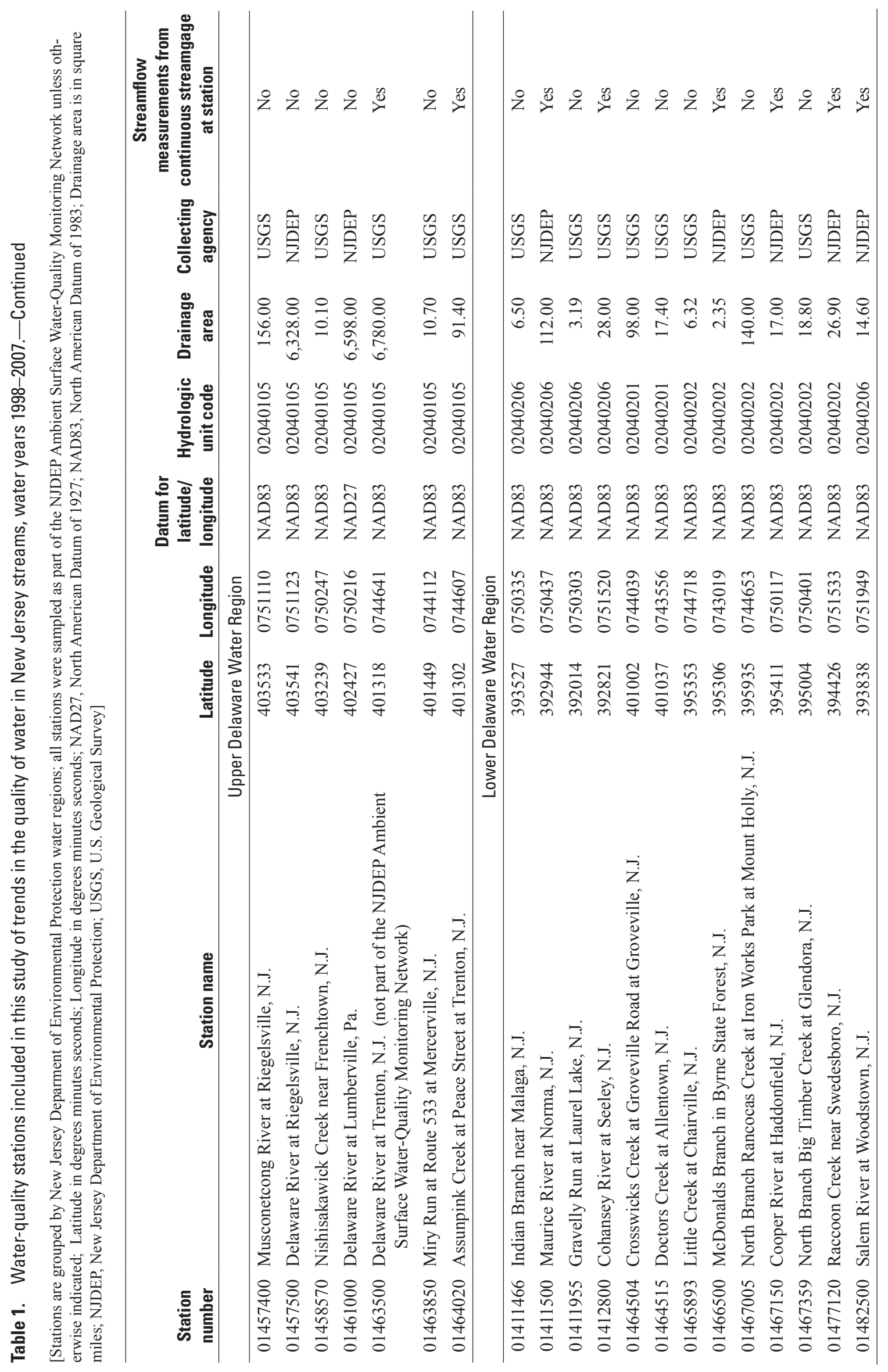


Table 2. References for methods of laboratory analyses of selected water-quality characteristics measured by the Ambient SurfaceWater Quality Monitoring Network, New Jersey, water years 1998-2007.

\begin{tabular}{|c|c|c|}
\hline $\begin{array}{l}\text { Water-quality } \\
\text { characteristic }\end{array}$ & Comment & Reference for method of laboratory determination \\
\hline Total dissolved solids & For period of study & Fishman and Friedman (1989) \\
\hline \multirow[t]{2}{*}{ Total phosphorus } & $\begin{array}{l}\text { From the beginning of the period of study } \\
\text { through December } 31,2002\end{array}$ & Patton and Truitt (1992) \\
\hline & January 1,2003 , to the end of the period of study & Patton and Kryskalla (2003) \\
\hline \multirow[t]{2}{*}{$\begin{array}{l}\text { Total organic nitrogen plus } \\
\text { ammonia }\end{array}$} & $\begin{array}{l}\text { From the beginning ot the period of study to } \\
\text { October } 1,1999\end{array}$ & Fishman and Friedman (1989) \\
\hline & $\begin{array}{l}\text { From about December, 2002, to the end of the } \\
\text { period of study }\end{array}$ & $\begin{array}{l}\text { Calculated }{ }^{1} \text { from laboratory-reported concen- } \\
\text { trations of dissolved organic nitrogen plus } \\
\text { ammonia (Fishman, 1993) and total particu- } \\
\text { late nitrogen (U.S. Environmental Protection } \\
\text { Agency, 1997) }\end{array}$ \\
\hline Dissolved nitrate plus nitrite & For period of study & Fishman (1993) \\
\hline
\end{tabular}

\footnotetext{
${ }^{1}$ Method of calculation is described in the text.
}

consisted of calculation from concentrations of dissolved organic nitrogen plus ammonia and total particulate nitrogen.

Each concentration value determined at USGS laboratories consists of a remark code and a numeric value. An uncensored value (remark code $=$ " " ") indicates that the concentration was reliably determined to be greater than or equal to the laboratory reporting level. An estimated value (remark code $=$ "E") indicates that the analyte was detected but could not be reliably quantified by the laboratory. A nondetect value $($ remark code $="<")$ indicates that the concentration was less than the reporting level. For a given characteristic, the reporting level sometimes changed during the period of study as a result of changes in methods or reporting protocols or because of the presence of substances in the sample that interfered with the analysis.

Instantaneous streamflow was measured at the time of each water-quality measurement or was estimated using methods described in Rantz and others (1982). Some streamflow values were taken from the records of the continuous streamgages at some of the stations (table 1). Values of streamflow at the station on the Delaware River at Lumberville, Pa. (01461000), were estimated from the record of the streamgage at the Delaware River at Trenton, N.J. (01463500).

\section{Development of Data Sets to be Analyzed}

Some of the water-quality values retrieved from the NWIS database were modified in order to provide a more accurate determination of trends than those that would have been calculated from unmodified values. These modifications are described below.

\section{Recensoring of some Nondetect Values}

For some nondetect values, the USGS National Water Quality Laboratory set laboratory reporting levels to twice the long-term method detection limit. This practice was used to minimize the probability of having a false positive and is discussed in Oblinger-Childress and others (1999). The authors note, however, that this practice also complicates interpretation of the data; results of statistical methods calculated with nondetects reported with laboratory reporting levels are biased.

To avoid this bias, laboratory reporting levels for nondetect values were set back to the long-term method detection level (half the laboratory reporting level). This was one action as suggested in Helsel (2005) to avoid bias. 


\section{Calculation of Total Organic Nitrogen plus Ammonia}

As noted in table 2, some values of total organic nitrogen plus ammonia $(T K N)$ were not determined by the laboratory but were calculated by summing concentrations of dissolved organic nitrogen plus ammonia $(D K N)$ and total particulate nitrogen $(T P N)$. The set of rules used for this calculation follows.

1. If $D K N$ and $T P N$ were both detected, the value of $T K N$ was determined by summing the numeric values of $D K N$ and $T P N$. The remark code for the $T K N$ value was set to "E" if the value of either $D K N$ or $T P N$ was estimated.

2. If either $D K N$ or $T P N$ was not detected and the other was detected, then:

(a) The ratio $(R)$ was determined from the following equation:

$$
R=100 *(T P N(T P N+D K N))
$$

where

$$
\begin{aligned}
R= & \text { ratio, in percent; } \\
T P N= & \text { numeric value of total particulate } \\
& \text { nitrogen, in } \mathrm{mg} / \mathrm{L} \text { as } \mathrm{N} ; \text { and } \\
D K N= & \text { numeric value of dissolved organic } \\
& \text { nitrogen plus ammonia, in } \mathrm{mg} / \mathrm{L} \text { as } \mathrm{N} .
\end{aligned}
$$

(b) If $D K N$ was detected, TPN was not detected, and the ratio, $R$, was less than or equal to 10 percent, $T K N$ was determined as follows:

(i) numeric value of $T K N$ was set equal to the numeric value of $D K N$, and

(ii) remark code of $T K N$ was set to the remark code for $D K N$.

(c) If $D K N$ was not detected or the ratio, $R$, was greater than 10 percent, $T K N$ was determined as follows:

$$
T K N=D K N+T P N
$$

where

$$
\begin{aligned}
T K N= & \text { numeric value of total organic } \\
& \text { nitrogen plus ammonia, in } \mathrm{mg} / \mathrm{L} \\
& \text { as } \mathrm{N} ; \\
D K N= & \text { numeric value of dissolved } \\
& \text { organic nitrogen plus ammonia, } \\
& \text { in } \mathrm{mg} / \mathrm{L} \text { as } \mathrm{N} ; \text { and } \\
T P N= & \text { numeric value of total particulate } \\
& \text { nitrogen, in } \mathrm{mg} / \mathrm{L} \text { as } \mathrm{N} .
\end{aligned}
$$

(ii) remark code for $T K N$ was set to " $<$ ".

\section{Selection of One Measurement in each Season of each Water Year}

For each water-quality characteristic, the number of water-quality measurements at each station was limited so that the summary statistics and results of trend tests were comparable among all stations. Four water-quality measurements were made in a water year at most stations included in this study. As a result, the water-quality measurements at each station were limited to four in a water year, one measurement in each of the seasonal months: October to December, January to March, April to June, and July to September. If there was more than one measurement of a water-quality characteristic at a station in any season in any water year, the measurement closest to the middle of the season was selected; the remaining measurements were not included in the analysis. For dissolved oxygen, a separate data set for the growing season was created by selecting one measurement in each of two seasons, April to June and July to September, in each water year.

\section{Calculation of Summary Statistics}

Summary statistics for the values of each water-quality characteristic at each station were determined from the measurements used for trend analysis (one measurement in each of four seasons over 10 water years). Statistics include the number of measurements; the number of nondetect measurements; the maximum reporting level for nondetect values; the minimum and maximum measured values; and the 25 th percentile, median, and 75 th percentile values. Summary statistics for dissolved oxygen were calculated only from year-round measurements.

The 25 th percentile, median, and 75 th percentile values of a water-quality characteristic at a station were determined if nondetect values accounted for less than 80 percent of the measured values at a station. One of three methods was used to determine these statistics for a water-quality characteristic at a station; that method was selected on the basis of the percentage of measurements made up of nondetect values. If there were no nondetect values, these statistics were calculated by use of the Univariate procedure (SAS Institute, Inc., 1999a) which ordered the values from smallest to largest.

If one or more measurements of a water-quality characteristic at a station were nondetects and if 50 percent or fewer of the measurements were nondetects, the Kaplan-Meier method (described in Helsel, 2005) was used to determine the 25 th percentile, median, and 75 th percentile values at that station. Kaplan-Meier is a standard method for estimating summary statistics on "survival" data, which are composed of uncensored values and right-censored values ("greater thans"). To use this method, the set of water-quality values was converted to a survival data set by subtracting all the values from a constant equal to twice the largest water-quality value. 
Summary statistics were determined on this survival data set by use of the Lifetest procedure (SAS Institute, Inc., 1999b). The resulting summary statistics were converted back to the original water-quality data set by subtracting them from the constant.

If nondetect measurements accounted for greater than 50 percent and less than 80 percent of the values at a station, the Regression on Order Statistics (ROS) method (described in Helsel, 2005) was used to determine the 25 th percentile, median, and 75 th percentile values at that station. This method is based on developing a linear relation between the logarithms of water-quality values as a function of normal quantiles. Calculations were done with a computer program obtained from the "Practical Statistics for the Sciences" website accessed July 19, 2005, at http://www.practicalstats.com/.

\section{Identification of Trends in Water Quality}

Procedures of the ESTREND program (Schertz and others, 1991) used to identify monotonic trends in flowadjusted concentrations of water quality were obtained from version 3.2 of the USGS library for S-PLUS (David Lorenz, U.S. Geological Survey, written commun., 2008), a commercial statistical software package produced by the Insightful Corporation (accessed at http://www.insightful.com/ on August 20, 2008). The features of the USGS library used for this study are essentially the same as those in version 2.1 described in Slack and others (2003) and at the website http://water.usgs.gov/software/S-PLUS/ (accessed August 8, 2008).

Three types of results are produced by the trend teststhe trend slope, the level of significance of the trend slope, and the summary. The trend slope is the "per year" change in the flow-adjusted water-quality values during water years 1998-2007. Each trend slope is expressed (1) in units of the water-quality characteristic and (2) as a percentage of a representative value (described below) of the water-quality characteristic. In some cases, only the direction of the slope is reported as "+" (indicating the value tended to increase over time) or "_." (indicating the value tended to decrease over time).

The level of significance of the trend slope indicates the probability that the trend slope is actually different from zero. A trend is not considered to exist if the level of significance of the trend test is greater than 0.05 . The value of the summary result for each of these tests is "no trend."

A trend is considered to exist if the level of significance of the trend test is less than or equal to 0.05 . If the trend slope is negative, the results indicate a monotonic decrease in flow-adjusted values of water quality during water years 1998-2007, and the value of the summary result for each of these tests is "Decrease." If the trend slope is positive, the results indicate a monotonic increase in flow-adjusted values of water quality during this period, and the value of the summary result is "Increase."

\section{Seasonal Kendall Test}

The Seasonal Kendall test (described in Schertz and others, 1991) was used to identify trends in flow-adjusted values of dissolved oxygen, $\mathrm{pH}$, and total dissolved solids; tests were conducted on the year-round values of all three characteristics as well as on dissolved oxygen concentrations measured during the growing season. This nonparametric test compares flow-adjusted water-quality values measured in each season throughout the period of study, and then calculates the trend in water quality from the results for all seasons included in the test.

For each Seasonal Kendall test, ESTREND set the representative value to be the median of water-quality values included in the test. These median values were computed with the Kaplan-Meier method (previously discussed) and, in some cases, may be slightly different than the medians presented in the tables of summary statistics, which were calculated separately and, possibly, with a different method.

The first step in running the Seasonal Kendall test on values of a water-quality characteristic at a station is to determine flow-adjusted values of water quality. To do this, a relation between untransformed values of water quality and instantaneous streamflow was developed. Flow-adjusted values are the differences between measured values and the values from the relation between water quality and streamflow.

Two methods were used to develop the relations between water quality and streamflow. Most relations were equations determined from linear regression; the form of these equations is given below:

$$
C=B_{0}+B_{1} * \log (Q)
$$

where

$$
\begin{aligned}
\log = & \text { natural logarithm; } \\
C= & \text { value of the water-quality characteristic, in } \\
& \text { water-quality units; } \\
B_{0}= & \text { intercept; } \\
B_{1}= & \text { coefficient for instantaneous streamflow; } \\
& \text { and } \\
Q \quad= & \text { instantaneous streamflow, in cubic feet per } \\
& \text { second. }
\end{aligned}
$$

A second method, LOESS smoothing (described in Schertz and others, 1991), was used in place of linear regression if the relation from LOESS smoothing appeared (from inspection of plots) to represent the overall relation between water quality and streamflow better than the relation from linear regression.

The results of the trend tests on $\mathrm{pH}$ were not reported if the results appeared to have been affected by a change in the methods of measurement. The apparent change in $\mathrm{pH}$ values due to the change in methods of measurement is discussed below. 
Results of trend tests for dissolved oxygen and $\mathrm{pH}$ are not presented if analyses clearly indicated that the results of the trend test were affected by a systematic change in time of measurement during the period of study. This effect was considered to exist if (1) there was a correlation between the values of water quality and the time of measurement and (2) there was a trend in the time of measurement. The correlation between values of water quality and the time of measurement was identified from Kendall's tau correlation (described in Helsel and Hirsch, 1992); the level of significance and the direction of each relation (whether water quality increased or decreased with increasing time of measurement) were determined. Trends in time of measurement were identified with the Seasonal Kendall trend test; however, times of measurement were not adjusted for streamflow. The direction of the trend slope (increase or decrease) and the level of significance of the trend slope also were determined.

\section{Tobit Regression}

Tobit regression (described in Helsel and Hirsch, 1992, and in Cohn, 1988) was used to identify trends in flowadjusted values of total phosphorus, total organic nitrogen plus ammonia, and dissolved nitrate plus nitrite at each station. Tobit regression was used because there were nondetect values of each of these water-quality characteristics at some stations, and Tobit regression can incorporate the information in nondetect values as well as the information in uncensored values. Tobit regressions were conducted if there were 15 or more uncensored or estimated water-quality measurements at a station.

Using Tobit regression, an equation relating values of a water-quality characteristic at a station to year, streamflow, and season was developed. The form of this equation is given below.

$$
\begin{aligned}
\log (C)= & B_{0}+\left(B_{1} * \text { Year }\right)+\left(B_{2} * \log (Q)\right) \\
& +\left(B_{3} * \cos (2 \pi * \text { Year })\right) \\
& +\left(B_{4} * \sin (2 \pi * \text { Year })\right)
\end{aligned}
$$

where

$$
\begin{aligned}
\log = & \text { natural logarithm; } \\
C= & \text { value water-quality characteristic, in water- } \\
& \text { quality units; }
\end{aligned}
$$

$$
\begin{aligned}
B_{0} & =\text { intercept; } \\
B_{1} & =\text { coefficient for Year; } \\
\text { Year } & =\text { decimal years from October 1, 1997; } \\
B_{2} & =\text { coefficient for instantaneous streamflow; } \\
Q & =\text { instantaneous streamflow, in cubic feet per } \\
& \text { second; } \\
B_{3}= & \text { coefficient for first seasonal term; } \\
\cos & =\text { cosine; } \\
B_{4} & =\text { coefficient for second seasonal term; } \\
\sin & =\text { sine. }
\end{aligned}
$$

Trend slopes (in units of water quality per year and percent of mean per year) were calculated from the value of the coefficient for "Year" $\left(B_{l}\right)$ by use of the equations below (Helsel and Hirsch, 1992). The level of significance of the trend slopes is the level of significance of $B_{l}$. The mean of waterquality values, from which the trend slope in water-quality units per year at each station was calculated, was determined by use of Regression on Order Statistics.

$$
\text { Trend }_{\mathrm{qw}}=C_{\text {mean }} *\left(\exp \left(B_{1}\right)-1\right),
$$

where

$$
\begin{aligned}
\text { Trend }_{\mathrm{qw}} & =\text { trend slope, in water-quality units per year; } \\
C_{\text {mean }} & =\text { mean of water-quality characteristic, in } \\
& \text { water-quality units; } \\
\exp & =\text { exponent; and } \\
B_{1} & =\text { coefficient for Year in equation } 4 .
\end{aligned}
$$

$$
\text { Trend }_{\mathrm{pct}}=100 *\left(\exp \left(B_{1}\right)-1\right)
$$

where

$$
\begin{aligned}
\text { Trend }_{\mathrm{pct}} & =\text { trend slope, in percent of mean } \\
& \text { concentration per year; } \\
\exp & =\text { exponent; and } \\
B_{1} & =\text { coefficient for Year in equation } 4 .
\end{aligned}
$$

For each of the three water-quality characteristics, two trend tests were conducted on the data from most stations. One test was conducted on all measurements; a second test was conducted on all measurements, except the most extreme outlying point if such a point could be identified from plots of influence values as a function of date (David Lorenz, U.S. Geological Survey, written commun., 2008). 


\section{Comparison of Trends from this Study with Trends from Previous Studies}

Trends from this study were compared to the trends from studies conducted for New Jersey streams during water years 1980-86 (Hay and Campbell, 1990) and water years 1986-95 (Hickman and Barringer, 1999). For each water-quality characteristic, the percentages of the stations included in each study and that have a trend are shown in a bar chart. Also, the results of trend tests in a water-quality characteristic at selected stations are shown in a table with the results from the previous studies. Only trends identified by Hay and Campbell at the 0.05 level of significance were considered in this comparison.

These comparisons did not always include the same water-quality variables in all three studies. Table 3 lists the water-quality characteristics studied by Hay and Campbell (1990) and Hickman and Barringer (1999) that were compared with water-quality characteristics from this report. Trends in flow-adjusted concentrations of total phosphorus and dissolved nitrate plus nitrite were, in general, not determined by Hay and Campbell (1990).

\section{Comparison of pH Values before and after a Change in Field Methods}

A rank-sum test was used to determine whether $\mathrm{pH}$ values collected at each station prior to October 1, 2001, were, as a group, different from the group of measurements made at that station following this date. This nonparametric test is described in Helsel and Hirsch (1992). Differences were considered to exist at the 0.05 level of significance.

Table 3. Water-quality characteristics included in the study of water years 1998-2007 and in previous studies of trends of the quality of New Jersey streams.

[All analyses shown are in flow-adjusted values; n.a., trends in corresponding water-quality characteristic were not available]

\begin{tabular}{ccc}
\hline Water years 1998-2007 & \multicolumn{2}{c}{ Were compared with the results of trend analyses in } \\
\cline { 2 - 3 } & Hay and Campbell (1990), water years & Hickman and Barringer (1999), water years \\
$1980-86$ & $1986-95$
\end{tabular}

Dissolved oxygen, in milligrams per liter

$\mathrm{pH}$, in standard units

Total dissolved solids, in milligrams per liter

Total phosphorus, in milligrams per liter as $\mathrm{P}$

Total organic nitrogen plus ammonia, in milligrams per liter as $\mathrm{N}$
Dissolved oxygen, in milligrams per liter

$\mathrm{pH}$, in standard units

Sum of dissolved constituents, in milligrams per liter

n.a.

Total organic nitrogen, in milligrams per liter as $\mathrm{N}$
Dissolved oxygen, in milligrams per liter

$\mathrm{pH}$, in standard units

Total dissolved solids, in milligrams per liter

Total phosphorus, in milligrams per liter as $\mathrm{P}$

Total organic nitrogen, in milligrams per liter as $\mathrm{N}$

Total nitrate, in milligrams per liter as $\mathrm{N}$ 


\section{Trends in the Quality of Water in New Jersey Streams}

Summary statistics and results of trend tests are listed in tables at the end of this report. Information on dissolved oxygen is given in tables 4 (summary statistics), 5a (trend test results for year-round measurements), $5 \mathrm{~b}$ (trend test results for growing-season measurements), and $5 \mathrm{c}$ (selected trend test results for year-round and growing-season measurements). Information on $\mathrm{pH}$ is given in tables 6 (summary statistics) and 7 (trend test results), on total dissolved solids in tables 8 (summary statistics) and 9 (trend test results), on total phosphorus in tables 10 (summary statistics) and 11 (trend test results), on total organic nitrogen plus ammonia in tables 12 (summary statistics) and 13 (trend test results), and on dissolved nitrate plus nitrite in tables 14 (summary statistics) and 15 (trend test results). (Tables 4-15 are at the end of the report.)

Summary statistics are presented for measurements of a water-quality characteristic at a station even if the measurements were deemed not suitable to test for a trend because the reader may find the statistics useful. Each table of summary statistics contains an indication of whether trend results are presented for a station. Reasons why results of trend tests are not presented are discussed below.

Only a small change in level of significance determined whether or not a trend was identified. For example, a level of significance of 0.051 indicates no trend, but a level of significance of 0.050 indicates a trend. For their own purposes and with caution, readers may consider a trend to be indicated by a different level of significance.

\section{Trends Determined from the Seasonal Kendall Test}

Trends in dissolved oxygen, $\mathrm{pH}$, and total dissolved solids were identified from the Seasonal Kendall test. As an example, the application of the Seasonal Kendall trend test to total dissolved solids at the water-quality station on the Whippany River near Pine Brook, N.J. (01381800), is shown in figures $3 \mathrm{~A}, 3 \mathrm{~B}$, and $3 \mathrm{C}$. Measured concentrations of total dissolved solids as a function of streamflow are shown in figure $3 \mathrm{~A}$, along with concentrations predicted from a least-squares regression equation (shown in the figure) relating these concentrations to streamflow. Flow-adjusted concentrations were determined by subtracting (1) concentrations predicted from the equation from (2) measured concentrations; these flowadjusted concentrations are shown in figure 3B as a function of date.

The result of the Seasonal Kendall test indicates that flow-adjusted concentrations at the water-quality station on the Whippany River near Pine Brook, N.J. (01381800), increased during the period of study (table 9). The level of significance of the trend slope $(0.014)$ is less than 0.05 and indicates that there was a trend in the flow-adjusted concentrations. The trend slope, 9.6 milligrams per liter per year, is magnitude of this trend (fig. 3B). The trend slope and concentrations are shown as a function of date in figure $3 \mathrm{C}$.

\section{Dissolved Oxygen}

Results of trend tests of year-round flow-adjusted measurements of dissolved oxygen are presented for 66 stations (table 5a; fig. 4A). Decreases in concentrations over the period of study were identified at four stations; the slopes of these trends range from -0.13 to -0.255 milligrams per liter per year ( -1.3 to -3.2 percent of median concentrations per year). Increases in concentrations over the period of study were not identified at any station. Summary statistics for year-round measurements of dissolved oxygen are listed in table 4.

Results of trend tests of growing-season flow-adjusted measurements of dissolved oxygen are presented for 65 stations (table 5b; fig. 4B). Decreases in concentrations over the period of study were identified at four stations; the slopes of these trends range from -0.100 to -0.354 milligrams per liter per year ( -1.3 to -5.8 percent of medians per year). Increases in concentrations over the period of study were identified at four stations; the slopes of these trends range from 0.085 to 0.13 milligrams per liter per year ( 1 to 1.6 percent of median concentrations per year).

More trends in dissolved oxygen were identified from growing-season measurements (8 stations) than from yearround measurements ( 4 stations) (table $5 \mathrm{c}$ ). This was expected because growing-season measurements are more likely than year-round measurements to show the effects of biological and chemical processes removing or adding oxygen to a stream. During the growing season, water temperatures are usually greater than, and the rates of streamflow are usually less than, the corresponding values during the nongrowing season (October-March). As a result, dissolved oxygen concentrations during the growing season are more likely to differ in saturation than are concentrations during the nongrowing season and, by extension, year-round concentrations. The station on the Delaware River at Riegelsville, N.J. (01457500), was the only station for which trends were identified for both yearround and growing-season measurements; both trends indicate decreasing concentrations over the period of study.

Results of trend tests of year-round measurements of dissolved oxygen at four stations and in growing-season measurements at five stations were not presented because these results were clearly affected by a trend in time of measurement of dissolved oxygen (tables $5 \mathrm{a}$ and $5 \mathrm{~b}$, respectively). The results of those tests for trends in dissolved oxygen were set to "n.d." because (1) there was a trend in times of measurement and (2) dissolved oxygen correlated with the time of measurement. 

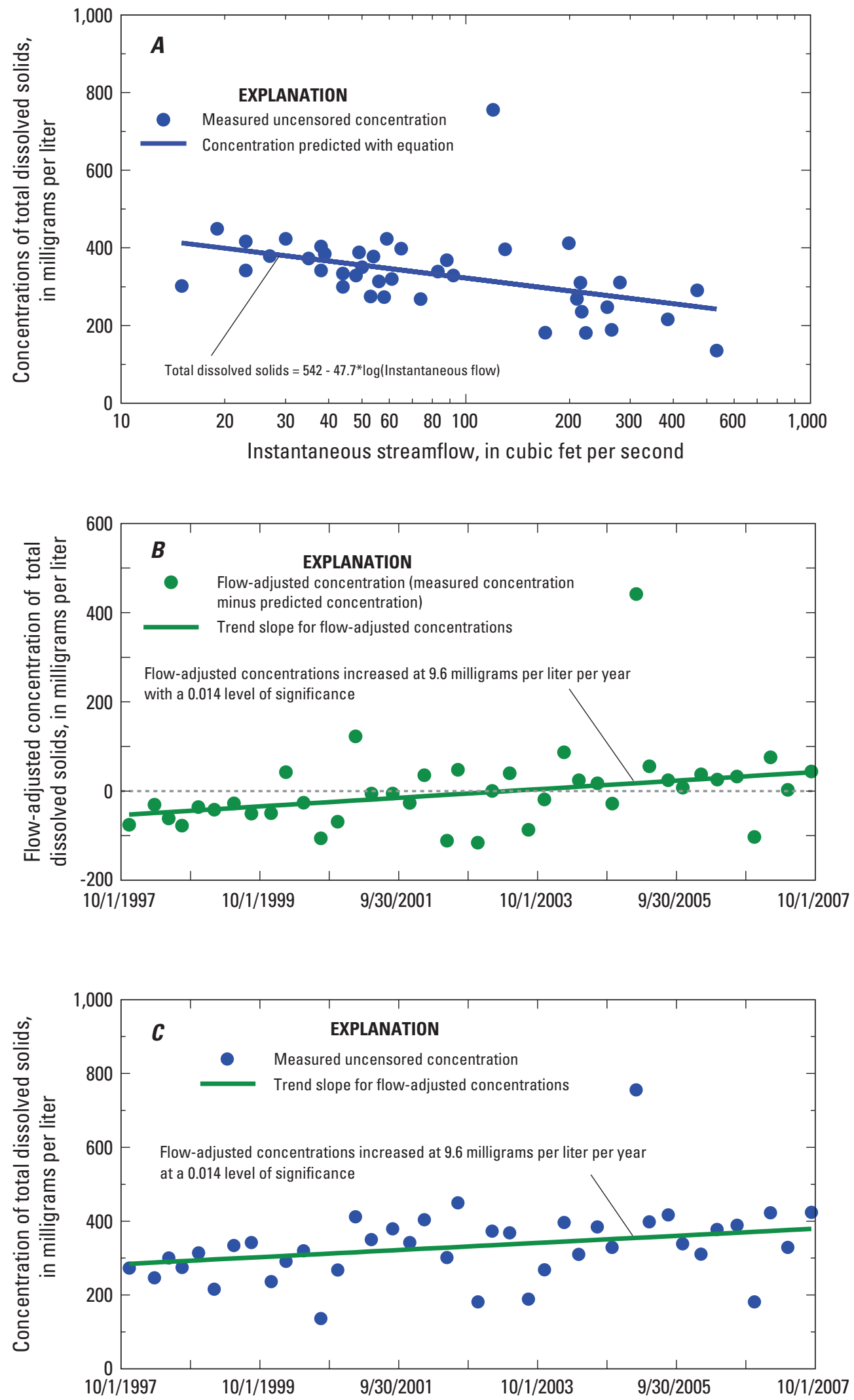

Figure 3. Results of the Seasonal Kendall trend test for concentrations of total dissolved solids at the water-quality station on the Whippany River near Pine Brook, N.J. (01381900), water years 1998-2007, $(A)$ concentrations as a function of streamflow, $(B)$ flow-adjusted concentrations and trend slope as a function of date, and $(C)$ concentrations and trend slope as a function of date. 


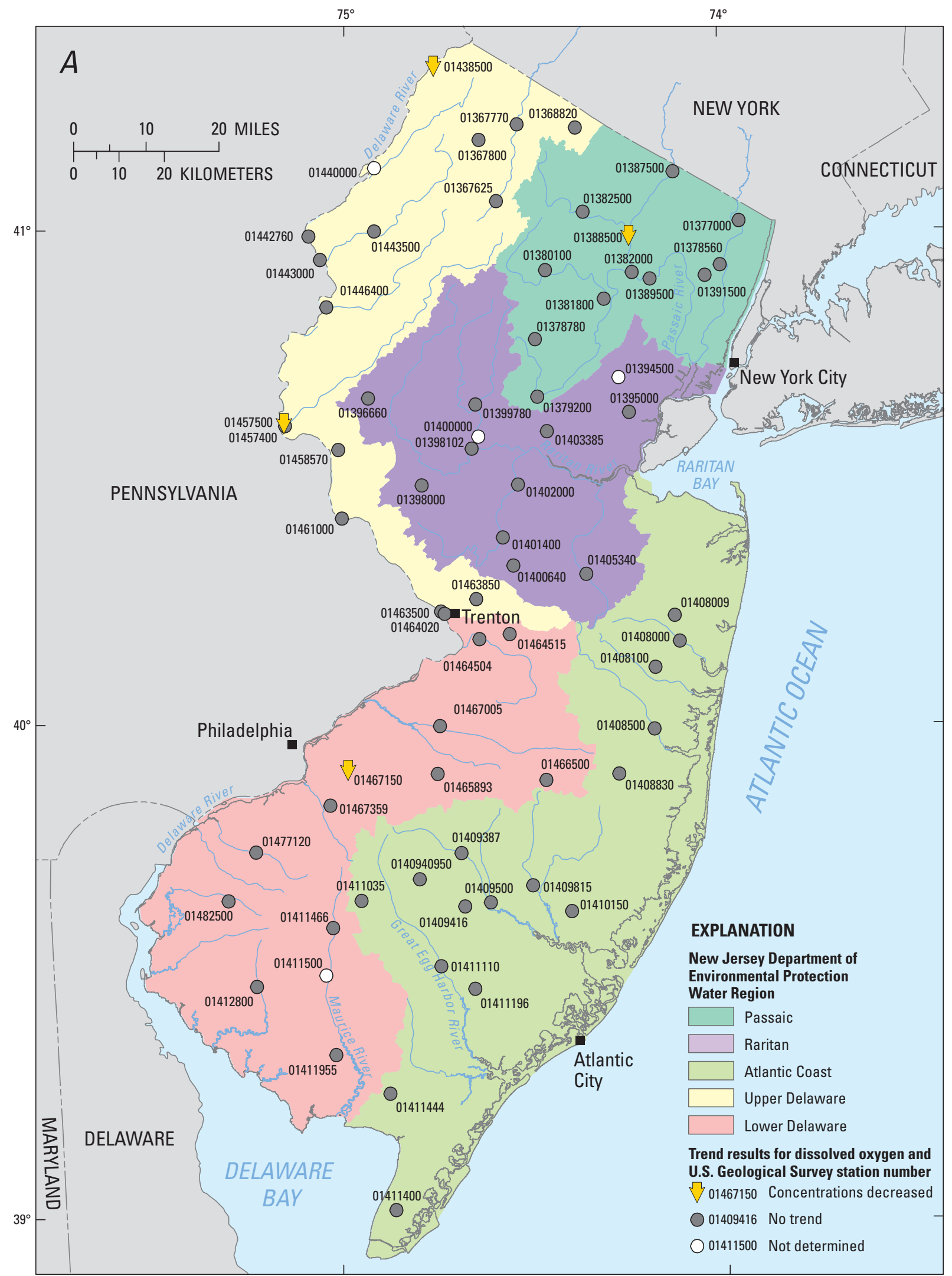

Base from U.S. Geological Survey digital line graph files, 1:24,000,

Universal Transverse Mercator projection, Zone 18, NAD83

Figure 4. Trends in $(A)$ year-round concentrations of dissolved oxygen and $(B)$ growing-season (April-September) concentrations of dissolved oxygen at water-quality stations on streams in New Jersey, water years 1998-2007. 


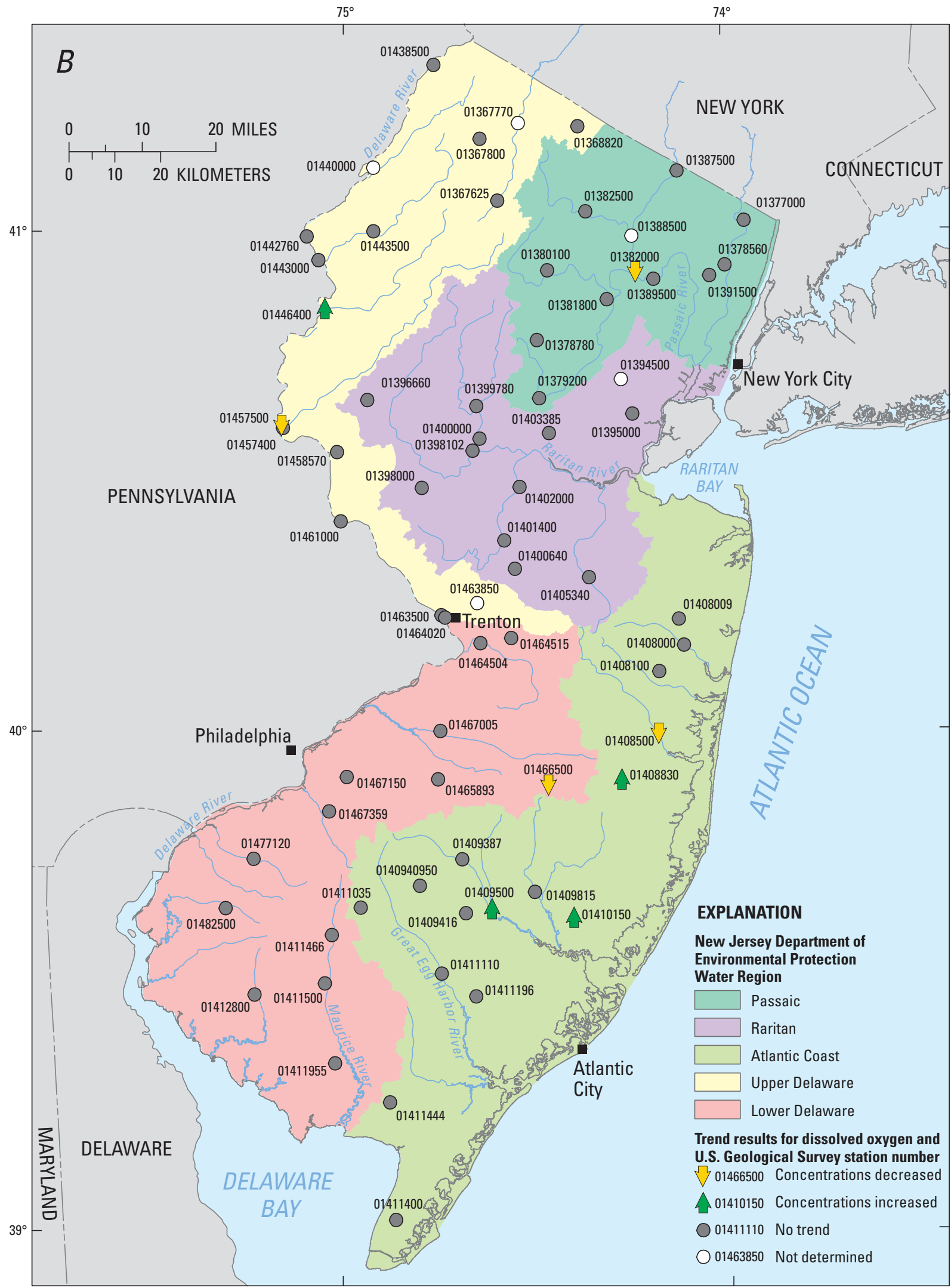

Base from U.S. Geological Survey digital line graph files, 1:24,000,

Universal Transverse Mercator projection, Zone 18, NAD83

Figure 4. Trends in $(A)$ year-round concentrations of dissolved oxygen and $(B)$ growing-season (April-September) concentrations of dissolved oxygen at water-quality stations on streams in New Jersey, water years 1998-2007.—Continued 
The consideration of trends in time of measurement was included in this study because (1) most of the measurements considered in this report were made during the morning or early afternoon and (2) dissolved oxygen concentrations measured during this period typically increase with time of day as a result of increasing photosynthesis as sunlight increases following sunrise. Values of dissolved oxygen at the water-quality station on the Delaware River at Trenton, N.J. (01463500), show this pattern (fig. 5).

The correlation between dissolved oxygen concentrations and time of measurement tends to support the theory that increasing photosynthesis during the day has been causing increased dissolved oxygen at some stations. Year-round concentrations at 11 stations increased with increasing time of measurement (table 5a); concentrations did not decrease at any station. When growing-season measurements were tested, concentrations at 17 stations increased with increasing time of measurement (table 5b); concentrations decreased at 2 stations.
As an example, the result of the trend test of growingseason dissolved oxygen at the station on Flat Brook near Flatbrookville, N.J. (01440000), clearly shows the effect of a trend in times of measurement. The result of the trend test of dissolved oxygen indicates that concentrations decreased over the period of study (fig. 6). However, because dissolved oxygen concentrations increased with time of measurement (table 5b), and the times of measurement decreased over the period of study (table 5b), the decrease in dissolved oxygen during the period of study can be attributed to the times of measurement, which are earlier during the second half of the period of study than those during the first half.

Results of trend tests of year-round flow-adjusted values of dissolved oxygen determined in this current study and the results of corresponding values from Hay and Campbell (1990) and Hickman and Barringer (1999) are shown for comparison in figure 7 and table 16. Neither of the previous studies looked for trends in times of measurement.

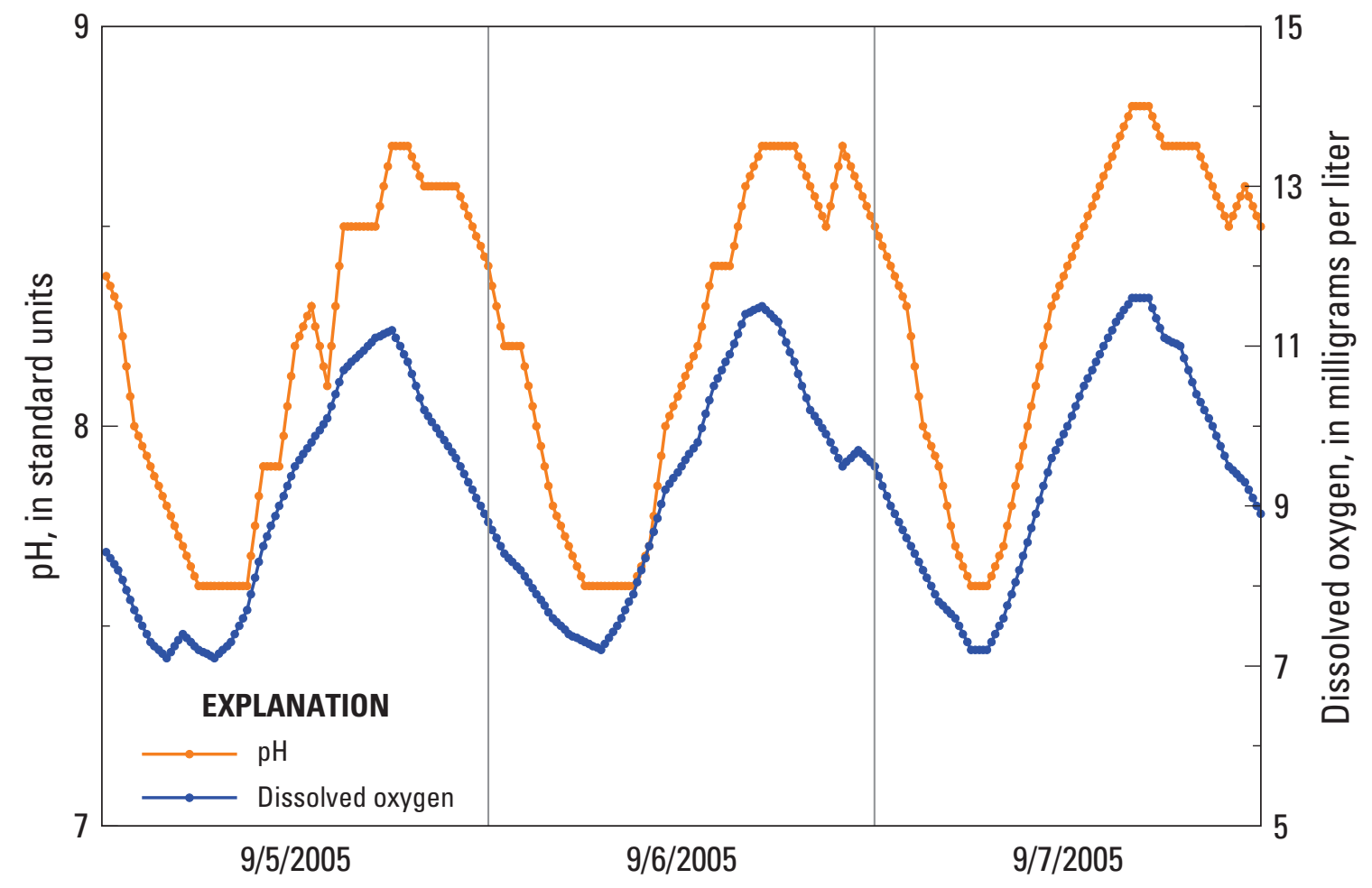

Figure 5. Values of $\mathrm{pH}$ and dissolved oxygen measured continually at the water-quality station on the Delaware River at Trenton, N.J. (01463500), September 5-7, 2005. 


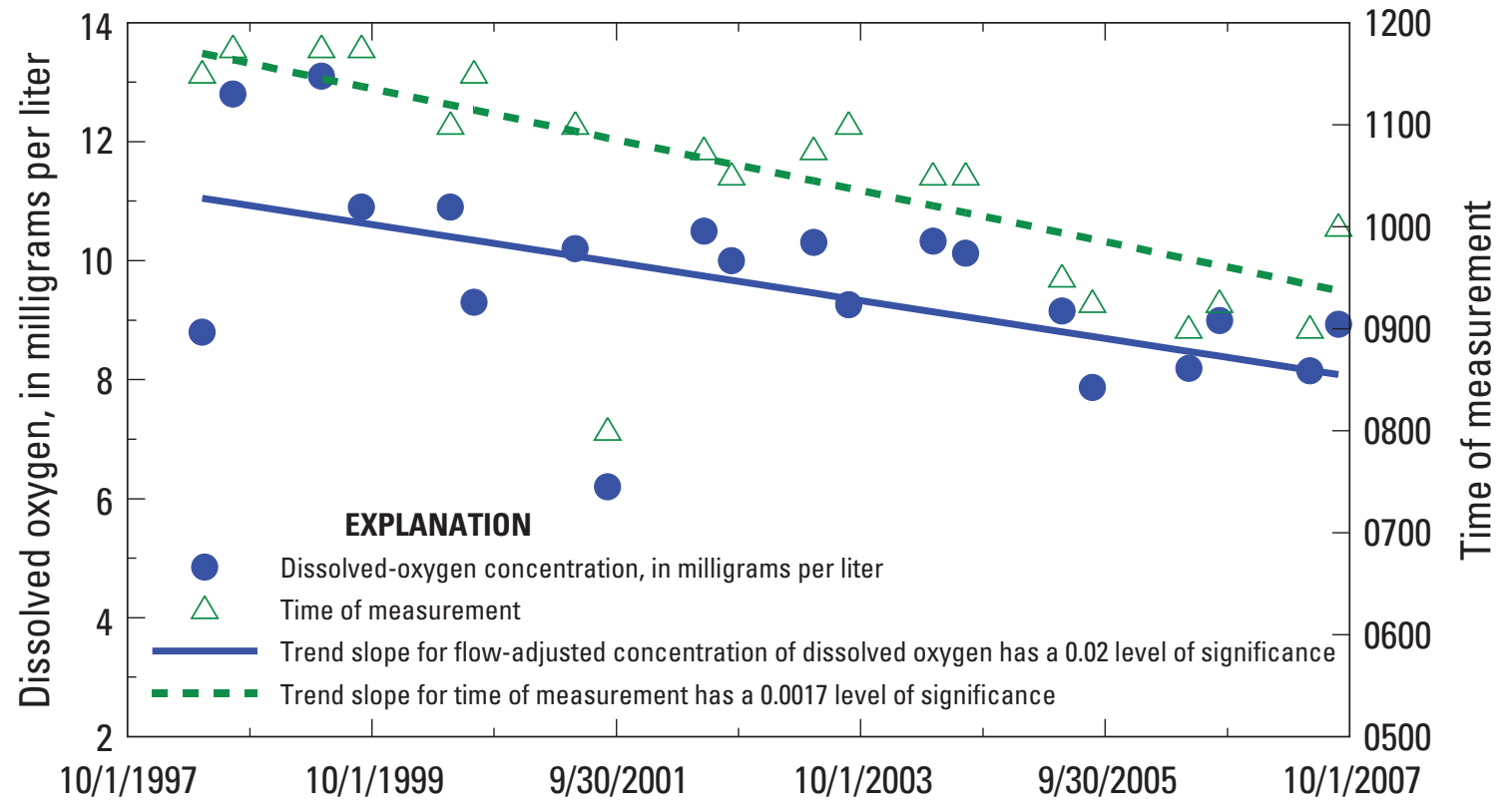

Figure 6. Growing-season concentrations of dissolved oxygen and times of measurement as a function of date at the water-quality station on Flat Brook near Flatbrookville, N.J. (01440000), water years 1998-2007.

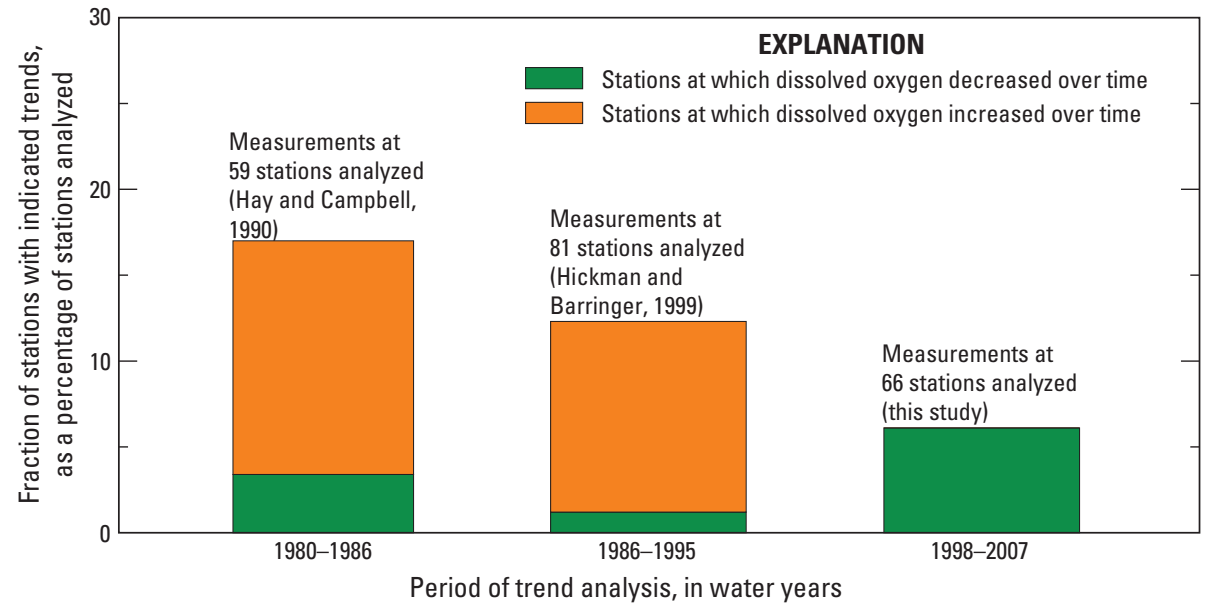

Figure 7. Fraction of water-quality stations on streams in New Jersey with trends in year-round flow-adjusted concentrations of dissolved oxygen during water years 1980-86, 1986-95, and 1998-2007. 
Table 16. Results of trend tests on flow-adjusted concentrations of dissolved oxygen during water years 1998-2007 and earlier periods at selected water-quality stations on New Jersey streams.

[Stations are listed if results were determined for the current and one previous study; --, no trend in flow-adjusted concentrations of dissolved oxygen during the period of study was identified at a 0.05 level of significance; Decrease, dissolved oxygen decreased during the period of study; Increase, dissolved oxygen increased during the period of study; n.d., not determined]

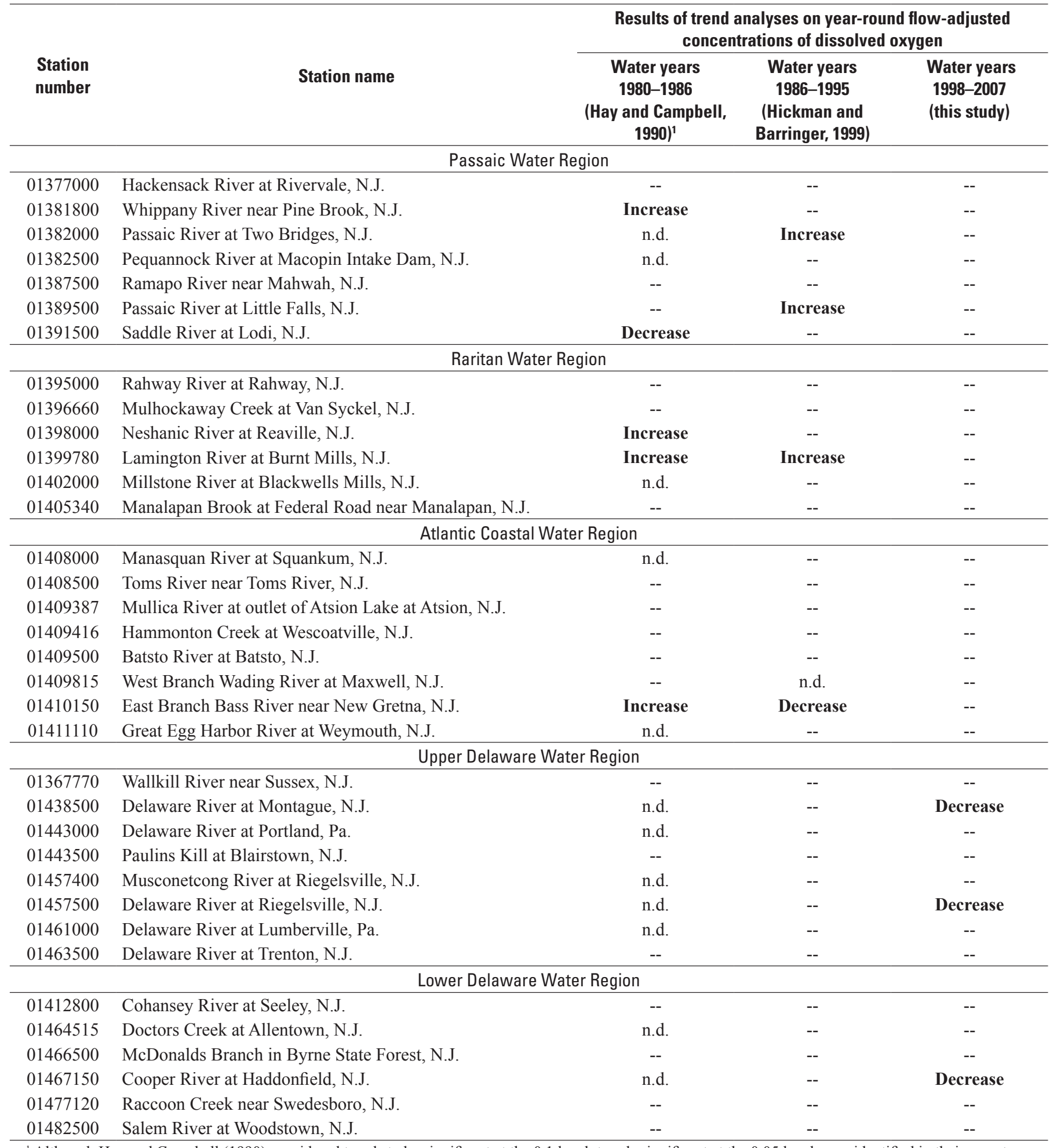

\footnotetext{
${ }^{1}$ Although Hay and Campbell (1990) considered trends to be significant at the 0.1 level, trends significant at the 0.05 level were identified in their report.
} 
$\mathrm{pH}$

Results of trend tests of $\mathrm{pH}$ were determined for 26 stations (table 7; fig. 8). Decreases in value were identified at two stations; the slopes of these trends fall in the range of -0.019 to $-0.028 \mathrm{pH}$ units per year $(-0.3$ to -0.4 percent of median $\mathrm{pH}$ per year). Increases in values were identified at three stations; the slopes of these trends fall in the range of 0.017 to $0.069 \mathrm{pH}$ units per year ( 0.2 to 0.9 percent of median $\mathrm{pH}$ per year). Summary statistics for $\mathrm{pH}$ are listed in table 6 .

Results of trend tests of $\mathrm{pH}$ are not presented for ASWQMN stations sampled by USGS personnel because an examination of time-series plots of $\mathrm{pH}$ values measured by USGS personnel indicated a step decrease near the start of water year 2002, which is apparently related to the change in USGS field methods previously discussed. The existence of this step decrease was verified by the results of a rank-sum test to compare values of $\mathrm{pH}$ measured prior to October 1, 2001, at a station to $\mathrm{pH}$ values at that station following that date. Results of these tests indicate that, at the 43 stations sampled by USGS personnel (other than 01463500), $\mathrm{pH}$ values following October 1, 2001, were less than prior $\mathrm{pH}$ values at 26 stations ( 60 percent) and greater than prior $\mathrm{pH}$ values at 0 stations. The results for the same tests at the 26 stations sampled by NJDEP personnel were quite different; $\mathrm{pH}$ values following October 1, 2001, were less than prior $\mathrm{pH}$ values at two stations (8 percent) and greater than prior $\mathrm{pH}$ values at two stations (8 percent). In response to this analysis, results of trend tests of $\mathrm{pH}$ for USGS-sampled stations (other than 01463500) were set to "n.d." (table 7).

Results of the trend test in $\mathrm{pH}$ at the station on the Cooper River at Haddonfield, N.J. (01467150) are not reported because they were affected by a trend in time of measurement (table 7). Values of $\mathrm{pH}$, like those of dissolved oxygen, typically vary diurnally because of the effects of photosynthesis (see figure 6 as an example). The effect of a trend in time of measurement on results of trends in $\mathrm{pH}$ values was examined as previously described for dissolved oxygen. The station on the Cooper River was the only station sampled by NJDEP at which there was a trend in time of $\mathrm{pH}$ measurement and a correlation between time of measurement and $\mathrm{pH}$ value.

Results of this study and those of previous studies are shown in figure 9 and table 17 for comparison. The fraction of stations with trends in $\mathrm{pH}$ during water years 1998-2007 was greater than the fraction of stations identified as having trends in the two previous studies (fig. 9). The number of stations analyzed for trends in $\mathrm{pH}$ in this study is far fewer than the number analyzed in the previous studies.

\section{Total Dissolved Solids}

Results of trend tests of total dissolved solids are reported for all 70 stations. Trends were identified at 24 stations (table 9; figure 10). All trends indicate increasing concentrations during the period of study; the slopes of these trends range from 0.6 to 12.9 milligrams per liter per year ( 0.9 to 5.3 percent of median concentrations). Increasing concentrations were identified at both stations (01394500 and 01395000) on the Rahway River. Summary statistics for total dissolved solids are listed in table 8 .

Results of trend analysis of measurements of dissolved solids in this study and those of previous studies (Hay and Campbell, 1990; Hickman and Barringer, 1999) are shown in figure 11 for comparison. The fraction of stations at which concentrations of total dissolved solids increased during water years 1998-2007 (34 percent) is greater than the corresponding fraction of stations with increasing concentrations during water years 1980-86 (24 percent) and water years 1986-95 (26 percent). The trend tests for water years 1980-86 were conducted on the sums of dissolved solids, which are very similar to values of total dissolved solids. Results of trend tests for individual stations are presented in table 18 . 


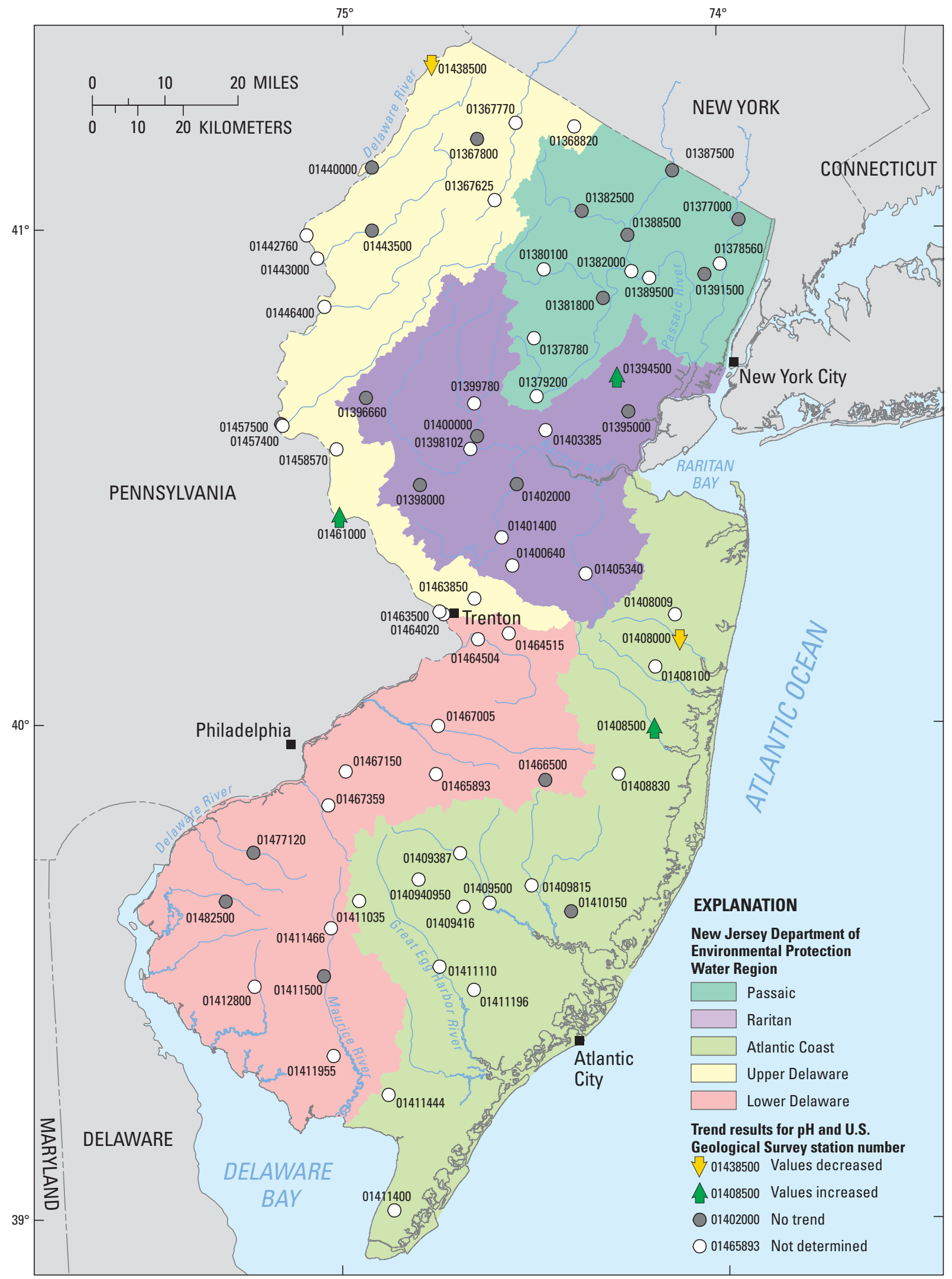

Base from U.S. Geological Survey digital line graph files, 1:24,000,

Universal Transverse Mercator projection, Zone 18, NAD83

Figure 8. Trends in pH at water-quality stations on streams in New Jersey, water years 1998-2007. 
Table 17. Results of trend tests on flow-adjusted values of pH during water years 1998-2007 and earlier periods at selected waterquality stations on New Jersey streams.

[Stations are listed if results were determined for the current and one previous study; --, no trend in flow-adjusted values of pH during the period of study was identified at a 0.05 level of significance; Decrease, $\mathrm{pH}$ values decreased during the period of study; Increase, $\mathrm{pH}$ values increased during the period of study; n.d., not determined]

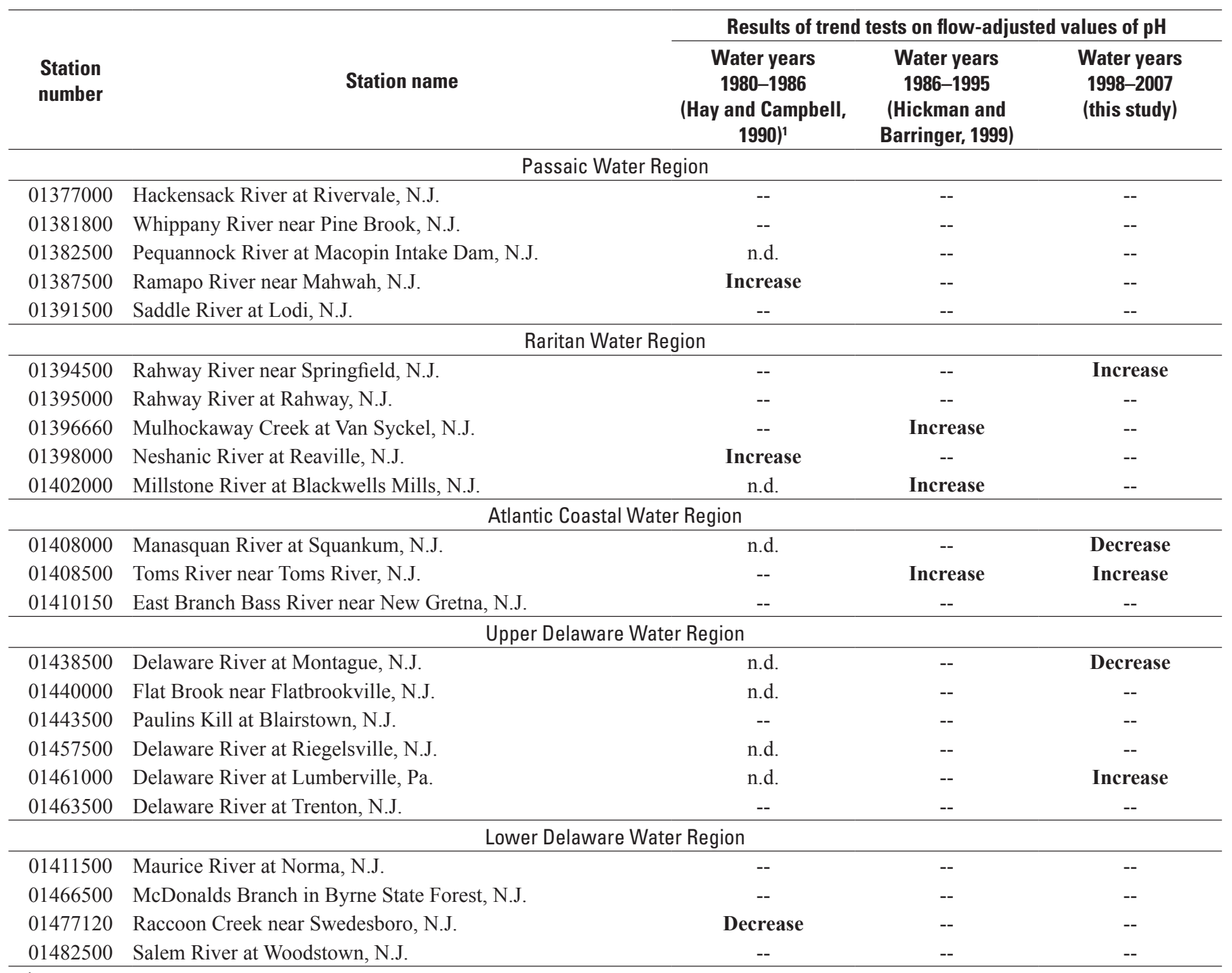

${ }^{1}$ Although Hay and Campbell (1990) considered trends to be significant at the 0.1 level, trends significant at the 0.05 level were identified in their report.

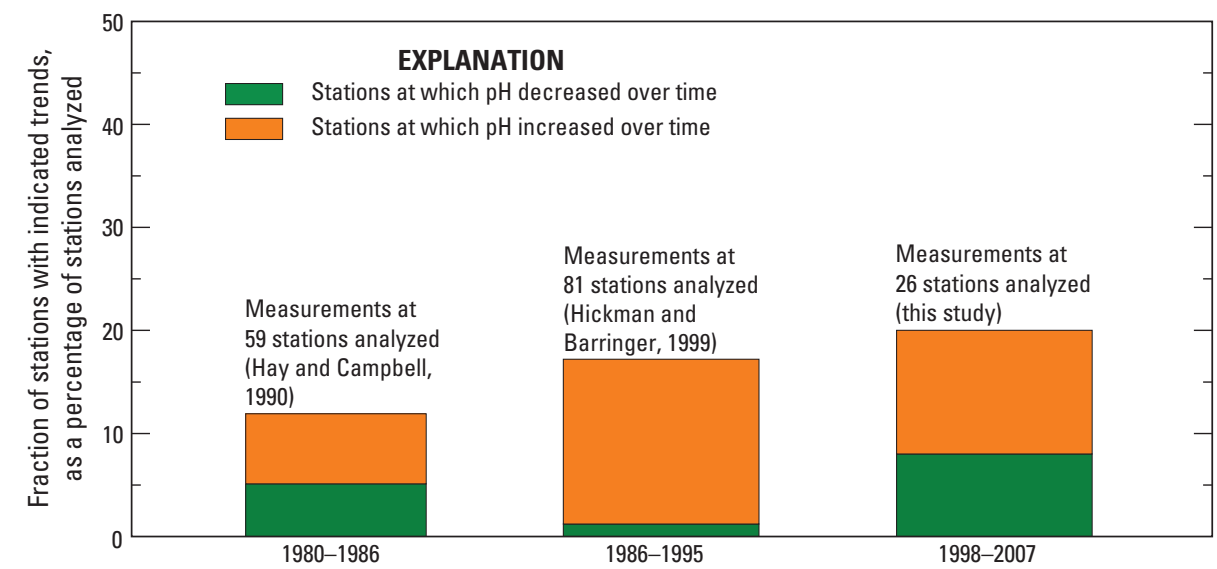

Period of trend analysis, in water years
Figure 9. Fraction of water-quality stations on streams in New Jersey with trends in flow-adjusted values of $\mathrm{pH}$ during water years 1980-86, 1986-95, and 1998-2007. 


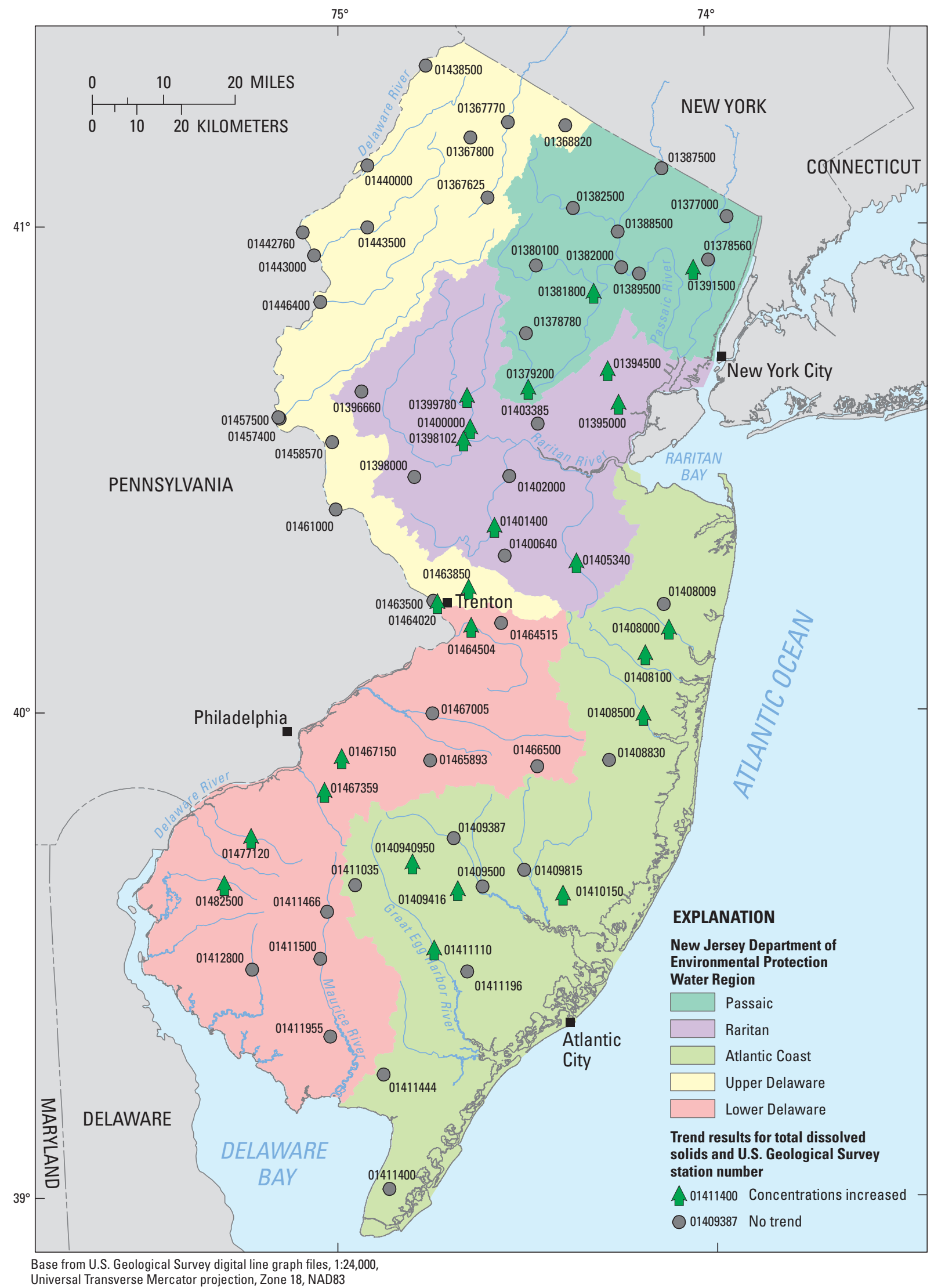

Figure 10. Trends in concentrations of total dissolved solids at water-quality stations on streams in New Jersey, water years 1998-2007. 
Table 18. Results of trend tests on flow-adjusted concentrations of dissolved solids during water years 1998-2007 and earlier periods at selected water-quality stations on New Jersey streams.

[Stations are listed if results were determined for the current and one previous study; --, no trend in flow-adjusted concentrations of dissolved solids during the period of study was identified at a 0.05 level of significance; Decrease, concentrations of dissolved solids decreased during the period of study; Increase, concentrations of dissolved solids increased during the period of study; n.d., not determined]

\begin{tabular}{|c|c|c|c|c|}
\hline \multirow[b]{2}{*}{$\begin{array}{l}\text { Station } \\
\text { number }\end{array}$} & \multirow[b]{2}{*}{ Station name } & \multicolumn{3}{|c|}{$\begin{array}{l}\text { Results of trend tests on flow-adjusted concentrations } \\
\text { of dissolved solids }\end{array}$} \\
\hline & & $\begin{array}{c}\text { Sum of dissolved } \\
\text { constituents, } \\
\text { water years } \\
\text { 1980-1986 } \\
\text { (Hay and Campbell, } \\
1990)^{1}\end{array}$ & $\begin{array}{c}\text { Total dissolved } \\
\text { solids, } \\
\text { water years } \\
\text { 1986-1995 } \\
\text { (Hickman and } \\
\text { Barringer, 1999) }\end{array}$ & $\begin{array}{c}\text { Total dissolved } \\
\text { solids, } \\
\text { water years } \\
\text { 1998-2007 } \\
\text { (this study) }\end{array}$ \\
\hline \multicolumn{5}{|c|}{ Passaic Water Region } \\
\hline 01377000 & Hackensack River at Rivervale, N.J. & n.d. & -- & -- \\
\hline 01381800 & Whippany River near Pine Brook, N.J. & n.d. & -- & Increase \\
\hline 01382000 & Passaic River at Two Bridges, N.J. & n.d. & Increase & -- \\
\hline 01387500 & Ramapo River near Mahwah, N.J. & n.d. & -- & -- \\
\hline 01389500 & Passaic River at Little Falls, N.J. & -- & Increase & -- \\
\hline \multicolumn{5}{|c|}{ Raritan Water Region } \\
\hline 01396660 & Mulhockaway Creek at Van Syckel, N.J. & -- & Increase & -- \\
\hline 01398000 & Neshanic River at Reaville, N.J. & -- & -- & -- \\
\hline 01399780 & Lamington River at Burnt Mills, N.J. & -- & -- & Increase \\
\hline 01405340 & Manalapan Brook at Federal Road near Manalapan, N.J. & -- & -- & Increase \\
\hline \multicolumn{5}{|c|}{ Atlantic Coastal Water Region } \\
\hline 01408500 & Toms River near Toms River, N.J. & -- & n.d. & Increase \\
\hline 01409416 & Hammonton Creek at Wescoatville, N.J. & -- & -- & Increase \\
\hline 01409500 & Batsto River at Batsto, N.J. & -- & Decrease & -- \\
\hline 01409815 & West Branch Wading River at Maxwell, N.J. & -- & n.d. & -- \\
\hline 01410150 & East Branch Bass River near New Gretna, N.J. & -- & n.d. & Increase \\
\hline 01461000 & Delaware River at Lumberville, $\mathrm{Pa}$. & n.d. & -- & -- \\
\hline 01463500 & Delaware River at Trenton, N.J. & Increase & -- & -- \\
\hline \multicolumn{5}{|c|}{ Lower Delaware Water Region } \\
\hline 01411500 & Maurice River at Norma, N.J. & -- & -- & -- \\
\hline 01412800 & Cohansey River at Seeley, N.J. & -- & Increase & -- \\
\hline 01464515 & Doctors Creek at Allentown, N.J. & n.d. & -- & -- \\
\hline 01466500 & McDonalds Branch in Byrne State Forest, N.J. & -- & n.d. & -- \\
\hline 01477120 & Raccoon Creek near Swedesboro, N.J. & -- & -- & Increase \\
\hline 01482500 & Salem River at Woodstown, N.J. & -- & -- & Increase \\
\hline
\end{tabular}

\footnotetext{
${ }^{1}$ Although Hay and Campbell (1990) considered trends to be significant at the 0.1 level, trends significant at the 0.05 level were identified in their report.
} 


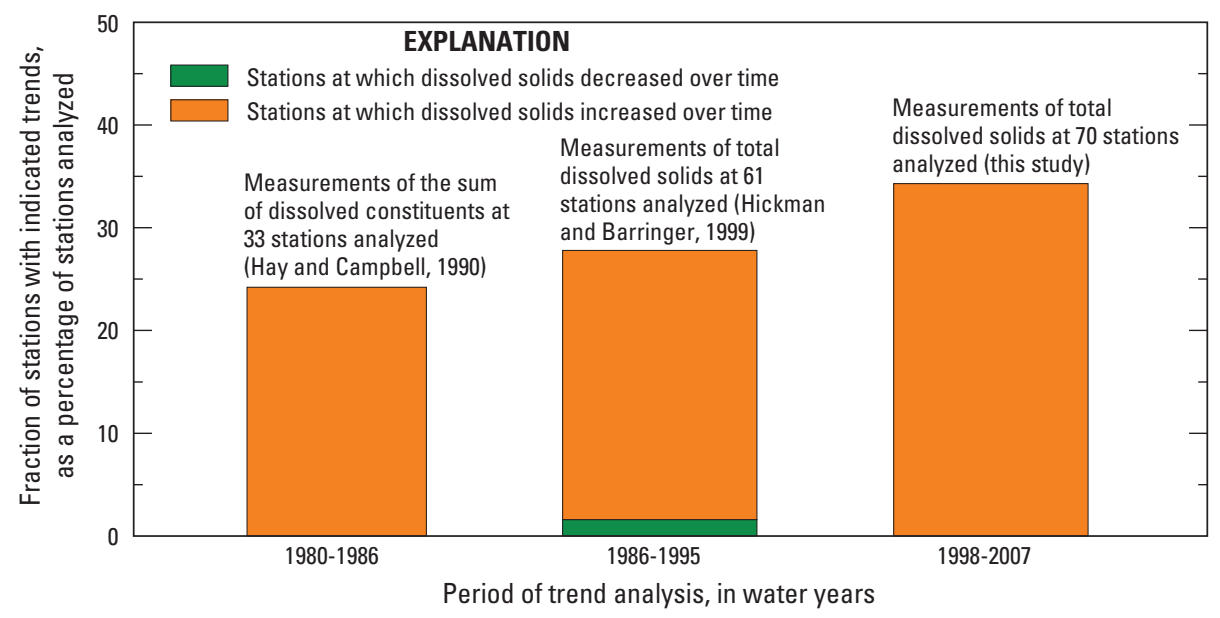

Figure 11. Fraction of water-quality stations with trends in flow-adjusted concentrations of dissolved solids during water years 1980-86, 1986-95, and 1998-2007.

\section{Trends determined from Tobit Regression}

Trends in flow-adjusted values of total phosphorus, total organic nitrogen plus ammonia, and dissolved nitrate plus nitrite were identified by use of tests with Tobit regression. For measurements of each water-quality characteristic at each station, the result presented is that of either the test with all water-quality measurements or the test with all measurements except the extreme outlier. If the results of the two tests were equivalent - either no trend, increasing values of water quality, or decreasing values of water quality, the result presented is from the test with all measurements. If the results of the two tests were not equivalent, the result presented is that from the test without the extreme outlier.

Tests were conducted with and without the most extreme outlier for two reasons. First, an extreme outlier may cause the residuals from the Tobit regression to be unevenly distributed, and the results of the regression are likely to be less accurate the less evenly distributed the residuals are. Second, this approach reduces the probability that the identification of a trend is due only to the influence of a single extreme outlier.

As an example, the application of Tobit regression to all measurements of total organic nitrogen plus ammonia at the water-quality station on the Pequannock River at the Macopin Intake Dam (01382500) is shown in figures 12A and 12B. Measured concentrations as a function of concentrations predicted with the equation produced by Tobit regression are shown in figure 12A.

The result of the Tobit regression trend test indicates that flow-adjusted concentrations of total organic nitrogen plus ammonia at the water-quality station on the Pequannock River at the Macopin Intake Dam (01382500) increased during the period of study (table 13). The level of significance of the trend slope (0.001) is the level of significance of the coefficient for "Year" in equation 4. The trend slope for the flow-adjusted concentrations was determined to be 0.036 milligrams per liter as nitrogen $(\mathrm{N})$ per year from the value of the coefficient for "Year" from equation 4 (0.0915) and equation 5. Given that the level of significance of the trend slope is less than 0.05 , flow-adjusted concentrations of total organic nitrogen plus ammonia at this station (01382500) increased during the period of study at the rate of change indicated by the trend slope. Measured concentrations, the concentrations predicted with equation 4 , and the trend slope as a function of date are shown in figure 12B.

\section{Total Phosphorus}

Results of trend tests of total phosphorus are reported for 69 stations (table 11 and fig. 13). A trend test was not conducted on values of total phosphorus at the water-quality station on McDonalds Branch in Byrne State Forest, N.J. (01466500), because there were an insufficient number of uncensored or estimated concentrations. Summary statistics for total phosphorus are listed in table 10.

Trends in total phosphorus concentration over the period of study were identified at 17 stations (table 11). Decreasing concentrations were identified for 12 stations; the slopes for these trends range from -0.001 to -0.055 milligrams per liter as phosphorus $(\mathrm{P})$ per year (-3.0 to -12.1 percent of mean concentrations per year). Increasing concentrations were identified for five stations; slopes for these trends range from 0.002 to 0.011 milligrams per liter as P per year (5.9 to 8.6 percent of mean concentrations per year).

For two reaches with two or more stations each, decreasing concentrations of total phosphorus over the period 

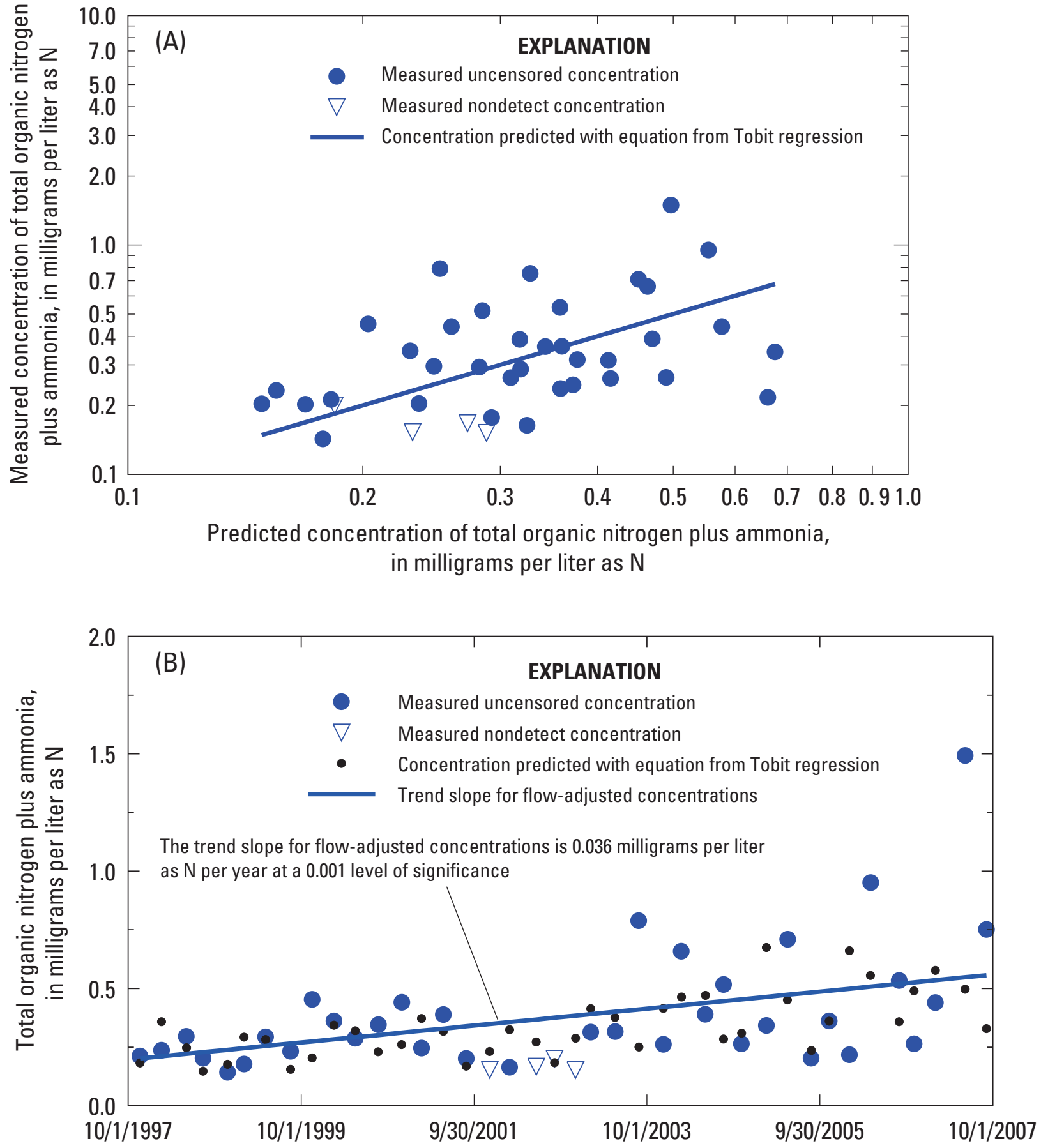

Figure 12. Results of trend analysis with Tobit regression for total organic nitrogen plus ammonia at the water-quality station on the Pequannock River at the Macopin Intake Dam, N.J. (01382500), water years 1998-2007, (A) measured concentrations as a function of predicted concentrations and $(B)$ measured and predicted concentrations and trend slope as a function of date. 
of study were identified (table 11 and fig. 13). One reach extends from the station on the Whippany River near Pine Brook, N.J. (01381800), to the station on the Passaic River at Two Bridges, N.J. (01382000); decreasing concentrations were identified at both stations. The other reach is the Delaware River; four of the five stations were identified as having decreasing concentrations. These stations are located at Montague, N.J. (01438500), Riegelsville, N.J. (01457500), Lumberville, Pa. (01461000), and Trenton, N.J. (01463500).

The fraction of stations with trends in total phosphorus during water years 1998-2007 was smaller than the fraction of stations with trends during water years 1986-95 (fig. 14). Results for only those stations included in both studies are listed in table 19. Corresponding values for water years 1980-86 are not available.

\section{Total Organic Nitrogen plus Ammonia}

Results of trend tests of total organic nitrogen plus ammonia are reported for 69 stations (table 13 and fig. 15). Results for the water-quality station on Dunnfield Creek at Dunnfield, N.J. (01442760), are not presented because an insufficient number of uncensored or estimated values were available. Summary statistics for total organic nitrogen plus ammonia are listed in table 12.

Trends in concentrations of total organic nitrogen plus ammonia were identified at 15 stations (table 13). Concentrations decreased over the period of study at six stations; the slopes of these trends range from -0.008 to -0.093 milligrams per liter as $\mathrm{N}$ per year (-2.5 to -11.1 percent of mean values per year) (table 13; fig. 15). Concentrations increased during the period of study at nine stations; the slopes of these trends range from 0.005 to 0.041 milligrams per liter as $\mathrm{N}$ per year (1.8 to 11.4 percent of mean values per year).

The fraction of stations with trends in total organic nitrogen plus ammonia during water years 1998-2007 and those from previous studies of total organic nitrogen during water years $1980-86$ and total organic nitrogen plus ammonia during water years 1986-95 are shown in figure 16. Concentrations of total organic nitrogen typically are similar to concentrations of total organic nitrogen plus ammonia at many stations. Results of trend analyses for individual stations included in this and in one or more of the two previous studies are listed in table 20.

\section{Dissolved Nitrate plus Nitrite}

Of the 70 stations, results of trend tests of dissolved nitrate plus nitrite are presented for 66 (table 15; fig. 17). Trend tests were not conducted on four stations because an insufficient number of uncensored concentrations were available. Summary statistics for dissolved nitrate plus nitrite are listed in table 14.

Trends indicating decreasing concentrations during the period of study were identified at four stations (table 15; fig. 17); slopes of these trends range from -0.009 to -0.256 milligrams per liter as $\mathrm{N}$ per year ( -3.1 to -6.7 percent of mean values per year). Trends indicating increasing concentrations during the period of study were identified at 19 stations; slopes of these trends range from 0.009 to 0.117 milligrams per liter as $\mathrm{N}$ per year (2.2 to 8 percent of mean values per year).

The fraction of stations with trends in dissolved nitrate plus nitrite during water years 1998-2007 and the fraction of stations with trends in total nitrate during water years 1986-95 (Hickman and Barringer, 1999) are shown in figure 18. Concentrations of total nitrate are likely to be close to concentrations of dissolved nitrate plus nitrite. Results for stations included in this study and in Hickman and Barringer (1999) are listed in table 21 .

\section{Summary of Trends by Station}

A summary of the results for the six water-quality characteristics are presented in table 22 (at end of report) so that the reader can compare the results of all water-quality characteristics at a station. The table includes the results of tests of both year-round and growing-season values of dissolved oxygen. 


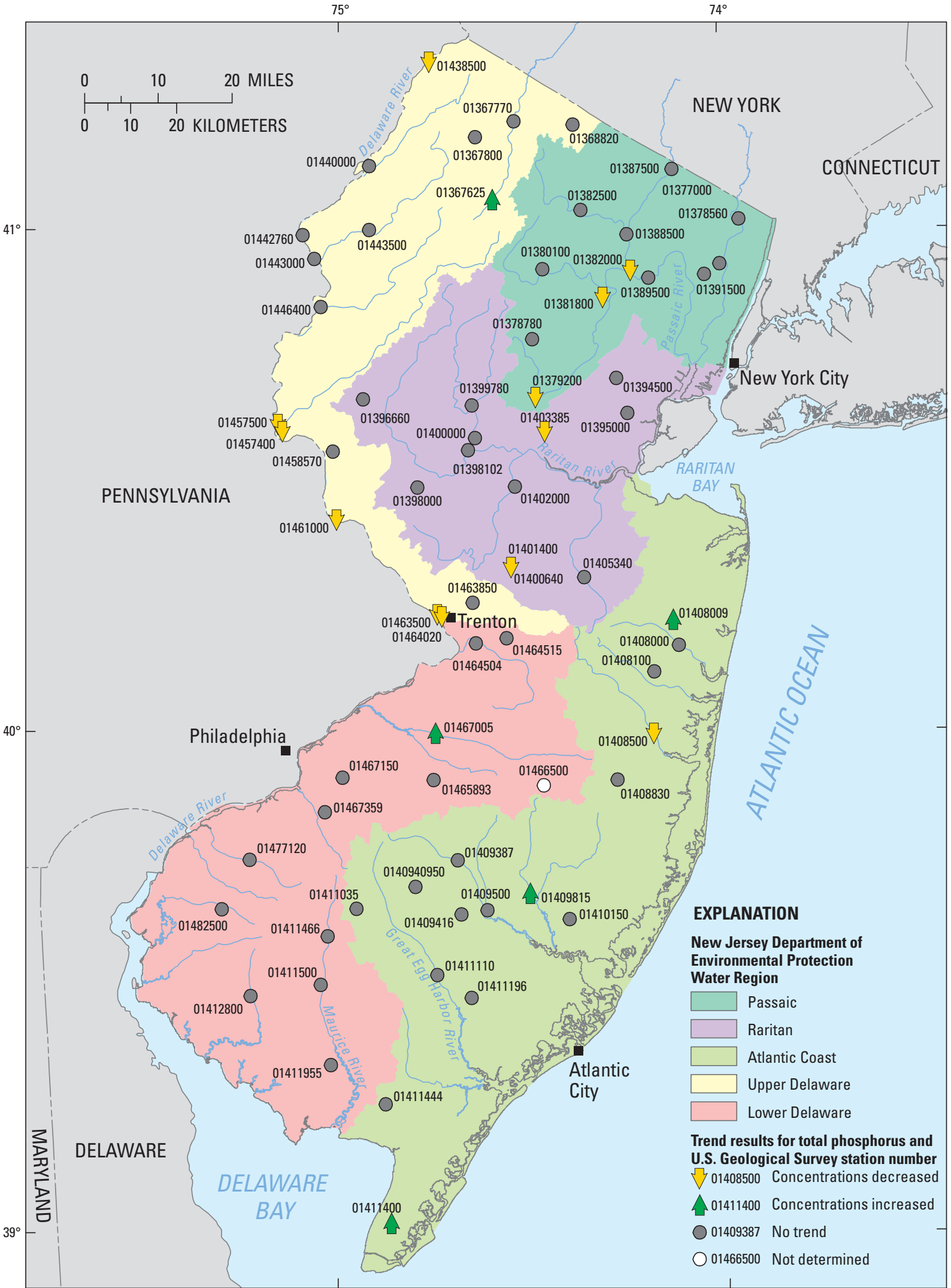

Base from U.S. Geological Survey digital line graph files, 1:24,000,

Universal Transverse Mercator projection, Zone 18, NAD83

Figure 13. Trends in concentrations of total phosphorus at water-quality stations on streams in New Jersey, water years 1998-2007. 


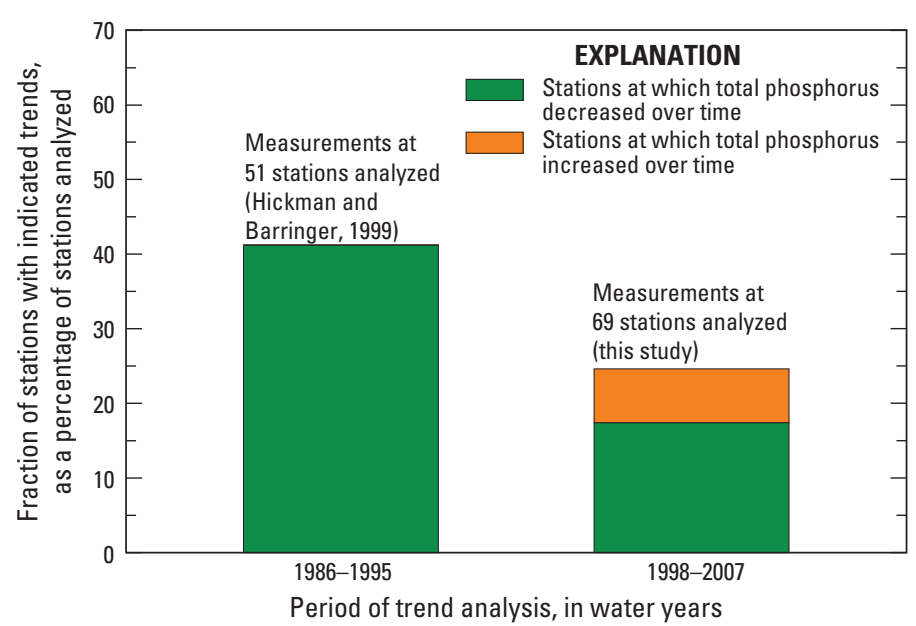

Figure 14. Fraction of water-quality stations with trends in flow-adjusted concentrations of total phosphorus during water years $1986-95$ and $1998-2007$.

Table 19. Results of trend tests on flow-adjusted concentrations of total phosphorus during water years 1998-2007 and water years 1986-1995 at selected water-quality stations on New Jersey streams.

[Stations are listed if results were determined for the current and the previous study; --, no trend in flow-adjusted concentrations of total phosphorus during the period of study was identified at a 0.05 level of significance; Decrease, total phosphorus decreased during the period of study]

\begin{tabular}{|c|c|c|c|}
\hline \multirow[b]{2}{*}{$\begin{array}{l}\text { Station } \\
\text { number }\end{array}$} & \multirow[b]{2}{*}{ Station name } & \multicolumn{2}{|c|}{$\begin{array}{l}\text { Results of trend tests on flow-adjusted } \\
\text { concentrations of total phosphorus }\end{array}$} \\
\hline & & $\begin{array}{c}\text { Water years } \\
\text { 1986-1995 } \\
\text { (Hickman and } \\
\text { Barringer, 1999) }\end{array}$ & $\begin{array}{l}\text { Water years } \\
\text { 1998-2007 } \\
\text { (this study) }\end{array}$ \\
\hline \multicolumn{4}{|c|}{ Passaic Water Region } \\
\hline 01377000 & Hackensack River at Rivervale, N.J. & -- & -- \\
\hline 01381800 & Whippany River near Pine Brook, N.J. & Decrease & Decrease \\
\hline 01382000 & Passaic River at Two Bridges, N.J. & -- & Decrease \\
\hline 01387500 & Ramapo River near Mahwah, N.J. & -- & -- \\
\hline 01389500 & Passaic River at Little Falls, N.J. & -- & -- \\
\hline 01391500 & Saddle River at Lodi, N.J. & Decrease & -- \\
\hline \multicolumn{4}{|c|}{ Raritan Water Region } \\
\hline 01394500 & Rahway River near Springfield, N.J. & -- & -- \\
\hline 01395000 & Rahway River at Rahway, N.J. & -- & -- \\
\hline 01398000 & Neshanic River at Reaville, N.J. & -- & -- \\
\hline 01399780 & Lamington River at Burnt Mills, N.J. & -- & -- \\
\hline 01402000 & Millstone River at Blackwells Mills, N.J. & -- & -- \\
\hline 01405340 & Manalapan Brook at Federal Road near Manalapan, N.J. & -- & -- \\
\hline \multicolumn{4}{|c|}{ Atlantic Coastal Water Region } \\
\hline 01408000 & Manasquan River at Squankum, N.J. & -- & -- \\
\hline 01409416 & Hammonton Creek at Wescoatville, N.J. & Decrease & -- \\
\hline \multicolumn{4}{|c|}{ Upper Delaware Water Region } \\
\hline 01457500 & Delaware River at Riegelsville, N.J. & -- & Decrease \\
\hline 01461000 & Delaware River at Lumberville, $\mathrm{Pa}$. & -- & Decrease \\
\hline 01463500 & Delaware River at Trenton, N.J. & -- & Decrease \\
\hline \multicolumn{4}{|c|}{ Lower Delaware Water Region } \\
\hline 01464515 & Doctors Creek at Allentown, N.J. & Decrease & -- \\
\hline 01467150 & Cooper River at Haddonfield, N.J. & Decrease & -- \\
\hline 01477120 & Raccoon Creek near Swedesboro, N.J. & -- & -- \\
\hline 01482500 & Salem River at Woodstown, N.J. & -- & -- \\
\hline
\end{tabular}




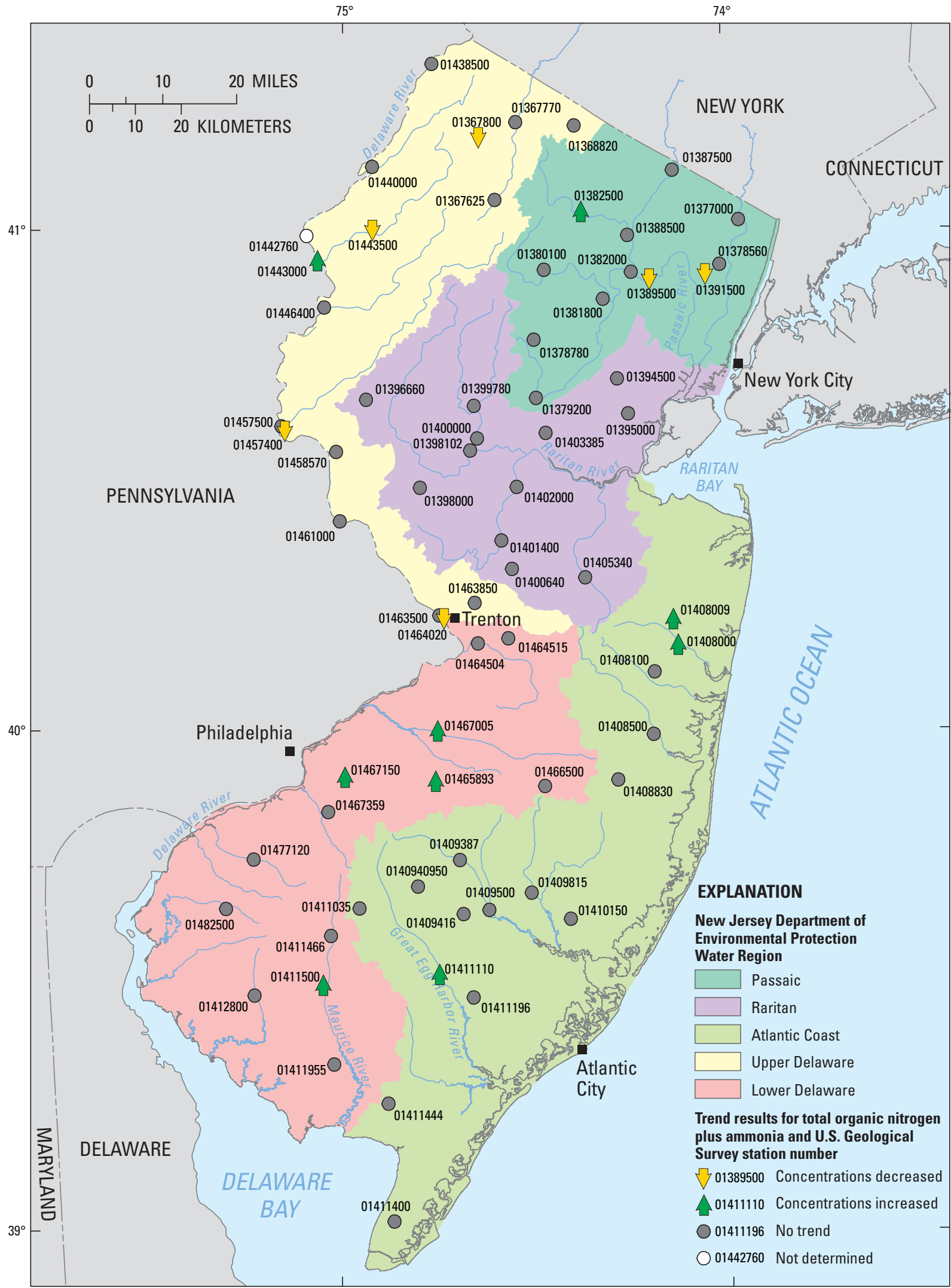

Base from U.S. Geological Survey digital line graph files, 1:24,000,

Universal Transverse Mercator projection, Zone 18, NAD83

Figure 15. Trends in concentrations of total organic nitrogen plus ammonia at water-quality stations on streams in New Jersey, water years 1998-2007. 


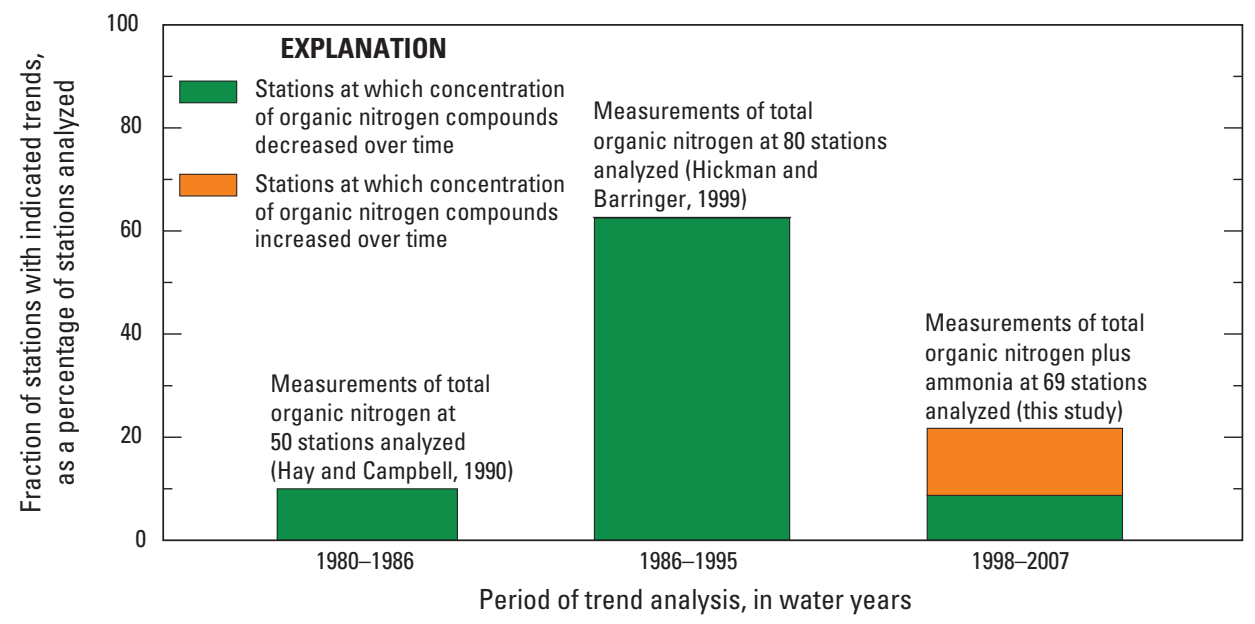

Figure 16. Fraction of water-quality stations with trends in flow-adjusted concentrations of organic nitrogen compounds during water years 1980-86, 1986-95, and 1998-2007. 
Table 20. Results of trend tests on flow-adjusted concentrations of organic nitrogen compounds during water years 1998-2007 and earlier periods at selected water-quality stations on New Jersey streams.

[Stations are listed if results were determined for the current and one previous study; --, no trend in flow-adjusted concentrations of organic nitrogen compound during the period of study was identified at a 0.05 level of significance; Decrease, concentrations of organic nitrogen compound decreased during the period of study; Increase, concentrations of organic nitrogen compound increased during the period of study; n.d., not determined]

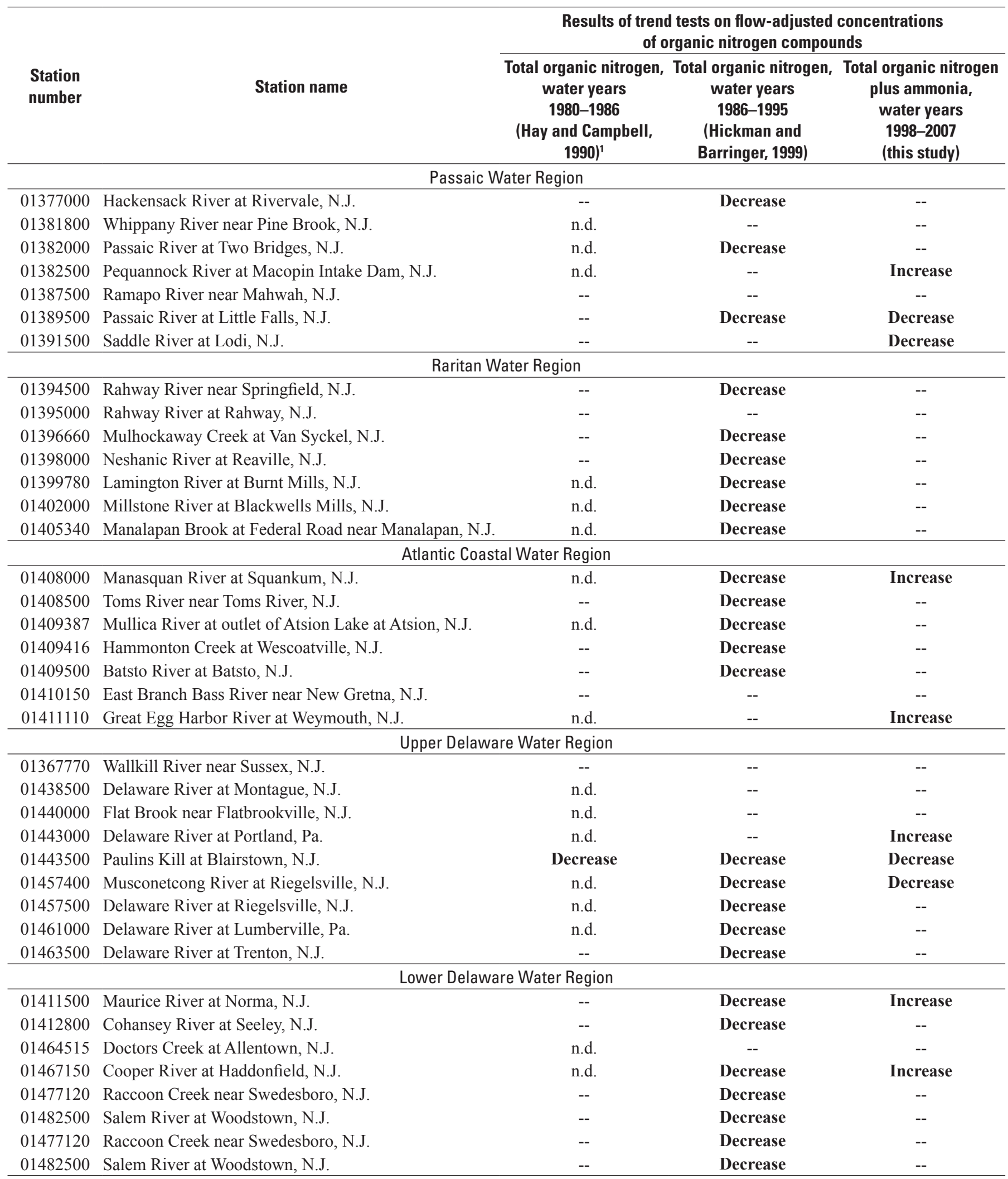

\footnotetext{
${ }^{1}$ Although Hay and Campbell (1990) considered trends to be significant at the 0.1 level, trends significant at the 0.05 level were identified in their report.
} 


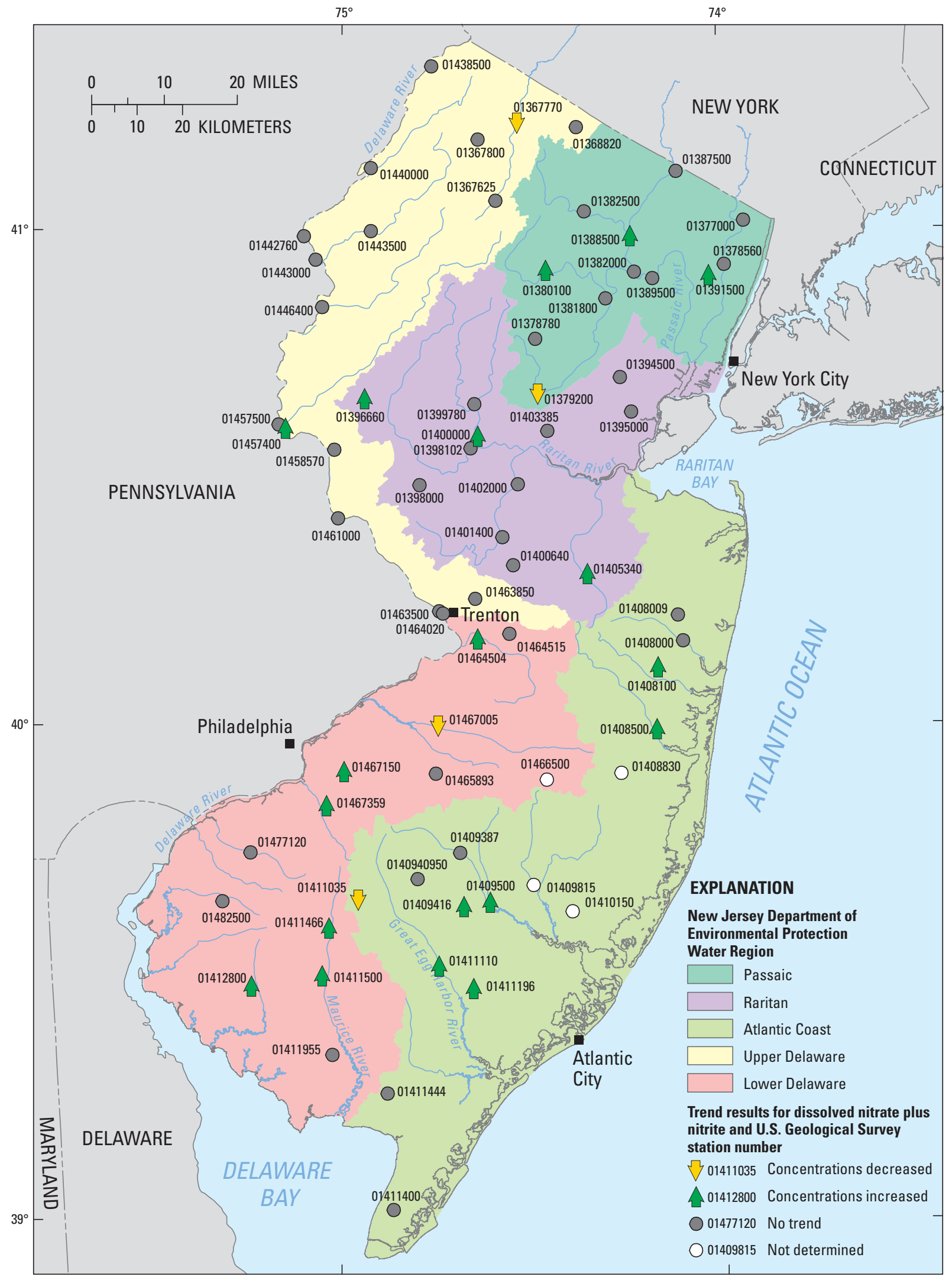

Base from U.S. Geological Survey digital line graph files, 1:24,000,

Universal Transverse Mercator projection, Zone 18, NAD83

Figure 17. Trends in concentrations of dissolved nitrate plus nitrite at water-quality stations on streams in New Jersey, water years 1998-2007. 


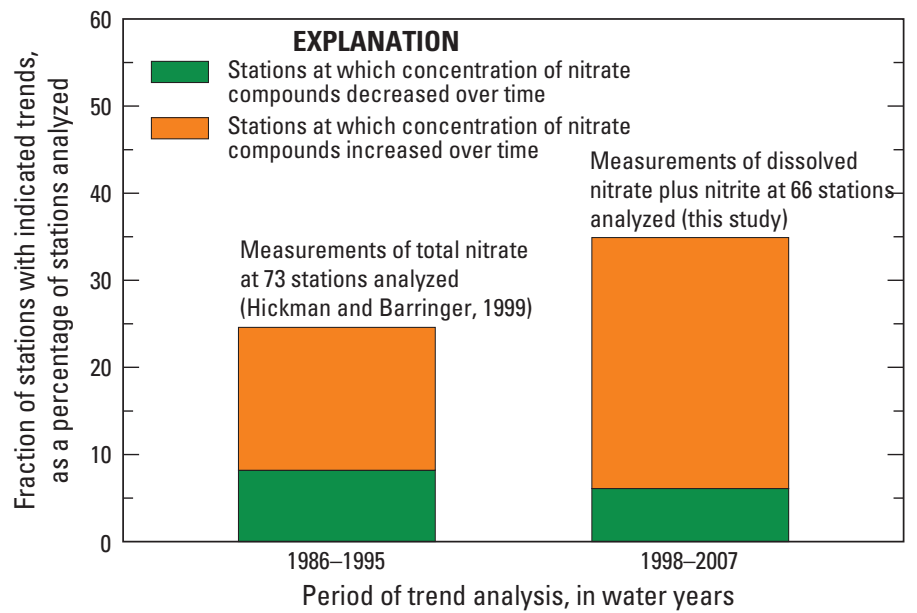

Figure 18. Fraction of water-quality stations with trends in flowadjusted concentrations of nitrate compounds during water years 1986-95 and 1998-2007. 
Table 21. Results of trend tests on flow-adjusted concentrations of nitrate compounds during water years 1998-2007 and water years 1986-1995 at selected water-quality stations on New Jersey streams.

[Stations are listed if results were determined for the current and previous study; --, no trend in flow-adjusted concentrations of the nitrate compound during the period of study was identified at a 0.05 level of significance; Decrease, nitrate compound decreased during the period of study; Increase, nitrate compound increased during the period of study; n.d., not determined]

\begin{tabular}{|c|c|c|c|}
\hline \multirow[b]{2}{*}{$\begin{array}{l}\text { Station } \\
\text { number }\end{array}$} & \multirow[b]{2}{*}{ Station name } & \multicolumn{2}{|c|}{$\begin{array}{l}\text { Results of trend tests on flow-adjusted } \\
\text { concentrations of nitrate compounds }\end{array}$} \\
\hline & & $\begin{array}{c}\text { Total nitrate, } \\
\text { water years } \\
\text { 1986-1995 } \\
\text { (Hickman and } \\
\text { Barringer, 1999) }\end{array}$ & $\begin{array}{c}\text { Dissolved nitrate } \\
\text { plus nitrite, } \\
\text { water years } \\
\text { 1998-2007 } \\
\text { (this study) }\end{array}$ \\
\hline \multicolumn{4}{|c|}{ Passaic Water Region } \\
\hline 01377000 & Hackensack River at Rivervale, N.J. & -- & -- \\
\hline 01381800 & Whippany River near Pine Brook, N.J. & Increase & -- \\
\hline 01382000 & Passaic River at Two Bridges, N.J. & Increase & -- \\
\hline 01382500 & Pequannock River at Macopin Intake Dam, N.J. & -- & -- \\
\hline 01387500 & Ramapo River near Mahwah, N.J. & -- & -- \\
\hline 01389500 & Passaic River at Little Falls, N.J. & Increase & -- \\
\hline 01391500 & Saddle River at Lodi, N.J. & Increase & Increase \\
\hline \multicolumn{4}{|c|}{ Raritan Water Region } \\
\hline 01394500 & Rahway River near Springfield, N.J. & -- & -- \\
\hline 01395000 & Rahway River at Rahway, N.J. & -- & -- \\
\hline 01396660 & Mulhockaway Creek at Van Syckel, N.J. & -- & Increase \\
\hline 01399780 & Lamington River at Burnt Mills, N.J. & -- & -- \\
\hline 01402000 & Millstone River at Blackwells Mills, N.J. & Increase & -- \\
\hline 01405340 & Manalapan Brook at Federal Road near Manalapan, N.J. & -- & Increase \\
\hline \multicolumn{4}{|c|}{ Atlantic Coastal Water Region } \\
\hline 01408000 & Manasquan River at Squankum, N.J. & -- & -- \\
\hline 01408500 & Toms River near Toms River, N.J. & Increase & Increase \\
\hline 01409416 & Hammonton Creek at Wescoatville, N.J. & -- & Increase \\
\hline 01411110 & Great Egg Harbor River at Weymouth, N.J. & -- & Increase \\
\hline \multicolumn{4}{|c|}{ Upper Delaware Water Region } \\
\hline 01367770 & Wallkill River near Sussex, N.J. & -- & Decrease \\
\hline 01438500 & Delaware River at Montague, N.J. & -- & -- \\
\hline 01443000 & Delaware River at Portland, Pa. & -- & -- \\
\hline 01443500 & Paulins Kill at Blairstown, N.J. & -- & -- \\
\hline 01457400 & Musconetcong River at Riegelsville, N.J. & -- & Increase \\
\hline 01457500 & Delaware River at Riegelsville, N.J. & -- & -- \\
\hline 01461000 & Delaware River at Lumberville, Pa. & -- & -- \\
\hline 01463500 & Delaware River at Trenton, N.J. & -- & -- \\
\hline \multicolumn{4}{|c|}{ Lower Delaware Water Region } \\
\hline 01411500 & Maurice River at Norma, N.J. & -- & Increase \\
\hline 01412800 & Cohansey River at Seeley, N.J. & Increase & Increase \\
\hline 01464515 & Doctors Creek at Allentown, N.J. & -- & -- \\
\hline 01467150 & Cooper River at Haddonfield, N.J. & Decrease & Increase \\
\hline 01477120 & Raccoon Creek near Swedesboro, N.J. & -- & -- \\
\hline
\end{tabular}




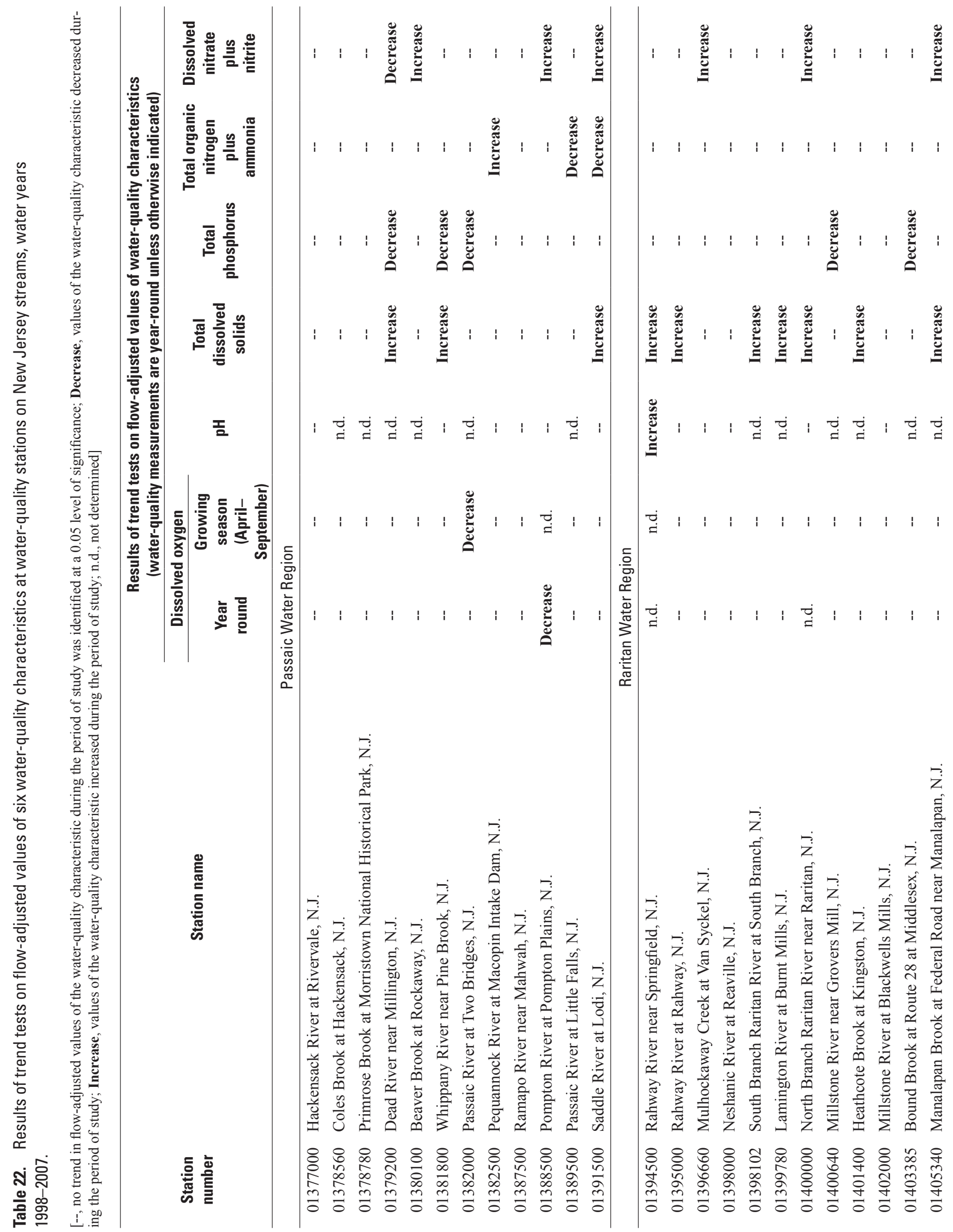




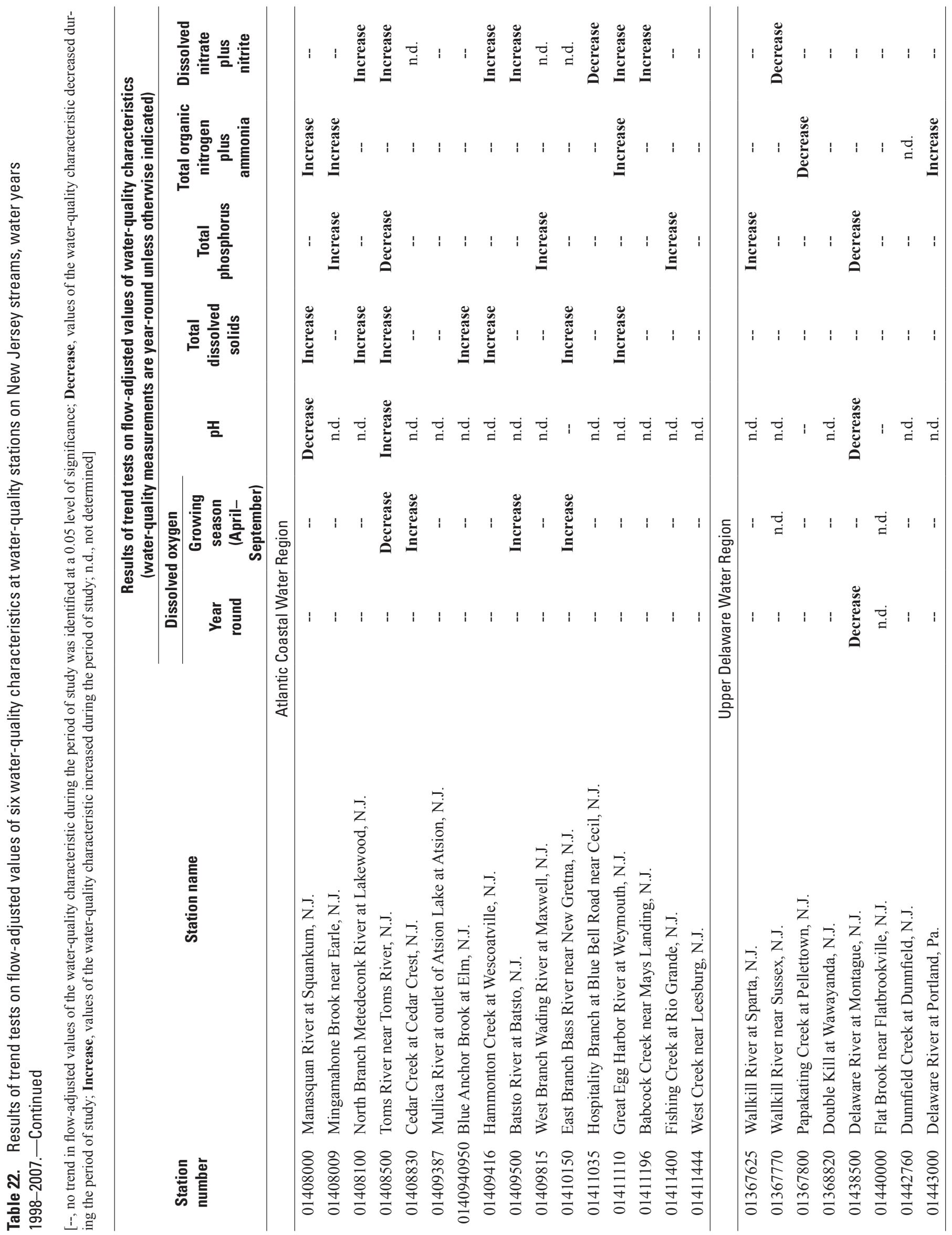




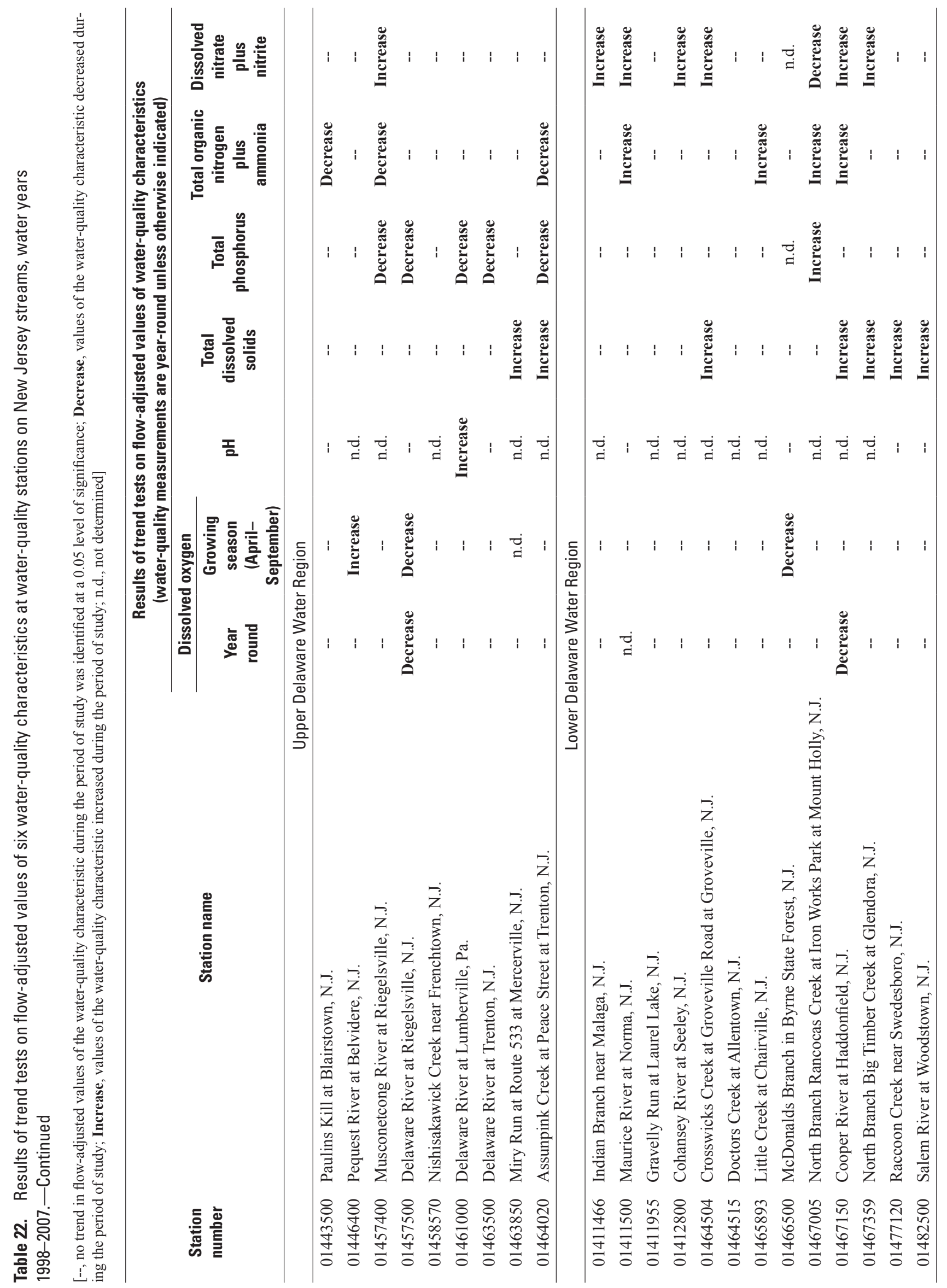




\section{Summary and Conclusions}

Trends in flow-adjusted values of selected water-quality characteristics measured year-round during water years 19982007 were determined for 70 stations on New Jersey streams. Water-quality characteristics included in the analysis are dissolved oxygen, $\mathrm{pH}$, total dissolved solids, total phosphorus, total organic nitrogen plus ammonia, and dissolved nitrate plus nitrite. Trend tests also were conducted on measurements of dissolved oxygen made only during the growing season, April-September. Nearly all of the water-quality data analyzed were collected by the NJDEP and the USGS as part of the New Jersey Department of Environmental Protection Ambient Surface-Water Quality Monitoring Network.

Monotonic trends in flow-adjusted values of water quality were determined by use of procedures of the ESTREND computer program. A 0.05 level of significance was selected to indicate a trend.

Trends in dissolved oxygen were identified with the Seasonal Kendall test. Tests of year-round values are reported for 66 stations; decreases and increases in concentration were identified at 4 and 0 stations, respectively. Tests of growingseason values are reported for 65 stations; decreases and increases in concentration were identified at 4 and 4 stations, respectively. Results of tests of year-round measurements and growing-season measurements are not reported for four and five stations, respectively, because these results were clearly affected by a trend in time of measurement.

Trends in $\mathrm{pH}$ were identified with the Seasonal Kendall test. Results are presented for 26 stations; decreasing and increasing values were identified at 2 and 3 stations, respectively. Results are not presented for ASWQMN stations sampled by the USGS because an examination of the $\mathrm{pH}$ values measured by the USGS indicated that they were affected by a change in field methods during the period of study. Results at one station are not presented because they were affected by a trend in time of measurement.

Trends in total dissolved solids were identified with the Seasonal Kendall test. Results are presented for 70 stations; decreases and increases in concentration were identified at 0 and 24 stations, respectively.

Trends in total phosphorus, total organic nitrogen plus ammonia, and dissolved nitrate plus nitrite were identified by use of Tobit regression. Tests were conducted on all measurements at each station and were repeated without the most extreme outlying point. The results presented are those from tests conducted on all measurements if the results of the two tests were equivalent. Otherwise, the results presented are those of the tests without the single outlier.

Results of tests of total phosphorus are presented for 69 stations. Decreases and increases in concentration were identified at 12 and 5 stations, respectively. Of the five stations on the Delaware River included in this study, decreases in concentration were identified at four.
Results of tests of total organic nitrogen plus ammonia are presented for 69 stations. Decreases and increases in concentration during the period of study were identified at six and nine stations, respectively.

Results of tests of dissolved nitrate plus nitrite are presented for 66 stations. Decreases and increases in concentration were identified at 4 and 19 stations, respectively.

Results of this study are compared with results of two previous studies of trends in the water quality of streams throughout New Jersey — one for water years 1980-86 and one for water years 1986-95. For example, the fractions of stations with trends in total dissolved solids or sum of dissolved solids were compared. Trends of increasing concentrations were identified at 24 percent of the stations analyzed during water years 1980-86, 26 percent of the stations analyzed during water years 1986-95, and 34 percent of stations analyzed during water years 1998-2007.

\section{References Cited}

Cohn, T.A., 1988, Adjusted maximum likelihood estimation of the moments of lognormal populations from Type I censored data: U.S. Geological Survey Open-File Report 88-350, $34 \mathrm{p}$.

DeLuca, M.J., Oden, J.H., Romanok, K.M., and Riskin, M.L., 1999, Water Resources Data, New Jersey, Water Year 1998, Volume 3, Water-Quality Data: U.S. Geological Survey Water-Data Report NJ-98-3, 450 p.

DeLuca, M.J., Romanok, K.M., Riskin, M.L., Mattes, G.L., Thomas, A.M., and Gray, B.J., 2000, Water Resources Data, New Jersey, Water Year 1999, Volume 3, Water-Quality Data: U.S. Geological Survey Water-Data Report NJ-99-3, $532 \mathrm{p}$.

DeLuca, M.J., Mattes, G.L., Burns, H.L., Thomas, A.M., Gray, B.J., and Doyle, H.A., 2001, Water Resources Data, New Jersey, Water Year 2000, Volume 3, Water-Quality Data: U.S. Geological Survey Water-Data Report NJ-00-3, 634 p.

DeLuca, M.J., Hoppe, H.L., Doyle, H.A., and Gray, B.J., 2002, Water Resources Data, New Jersey, Water Year 2001, Volume 3, Water-Quality Data: U.S. Geological Survey Water-Data Report NJ-01-3, 580 p.

DeLuca, M.J., Hoppe, H.L., Heckathorn, H.A., Gray, B.J.; and Riskin, M.L., 2003, Water Resources Data, New Jersey, Water Year 2002, Volume 3, Water-Quality Data: U.S. Geological Survey Water-Data Report NJ-02-3, 478 p.

DeLuca, M.J., Hoppe, H.L., Heckathorn, H.A., Riskin, M.L., Gray, B.J., Melvin, E.-L., Liu, N.A., 2004, Water Resources Data, New Jersey, Water Year 2003, Volume 3, WaterQuality Data: U.S. Geological Survey Water-Data Report NJ-03-3, 686 p. 
DeLuca, M.J., Heckathorn, H.A., Lewis, J.M., Gray, B.J., Melvin, E.-L., Riskin, M.L., Liu, N.A., 2005, Water Resources Data, New Jersey, Water Year 2004, Volume 3, WaterQuality Data: U.S. Geological Survey Water-Data Report NJ-04-3, 683 p.

DeLuca, M.J., Heckathorn, H.A., Lewis, J.M., Gray, B.J., and Feinson, L.S., 2006, Water Resources Data, New Jersey, Water Year 2005, Volume 3, Water-Quality Data: U.S. Geological Survey Water-Data Report NJ-05-3, 568 p.

Fishman, M.J., ed., 1993, Methods of analysis by the U.S. Geological Survey National Water Quality LaboratoryDetermination of inorganic and organic constituents in water and fluvial sediments: U.S. Geological Survey OpenFile Report 93-125, $217 \mathrm{p}$.

Fishman, M.J., and Friedman, L.C., 1989, Methods for determination of inorganic substances in water and fluvial sediments: U.S. Geological Survey Techniques of WaterResources Investigations, book 5, chap. A1, 545 p.

Hay, L.E., and Campbell, J.P., 1990, Water-quality trends in New Jersey streams: U.S. Geological Survey WaterResources Investigations Report 90-4046, 297 p.

Helsel, D.R., 2005, Nondetects and data analysis, statistics for censored environmental data: Hoboken, New Jersey, John Wiley \& Sons, Inc., 250 p.

Helsel, D.R., and Hirsch, R.M., 1992, Statistical methods in water resources: New York, Elsevier Science Publishing Company, Inc., 522 p.

Hickman, R.E., and Barringer, T.H., 1999, Trends in water quality of New Jersey streams, water years 1986-95: U.S. Geological Survey Water-Resources Investigations Report 98-4204, 174 p.

Mathey, S.B., ed., 1998, National Water Information System (NWIS): U.S. Geological Survey Fact Sheet FS-027-98, 2 p.

New Jersey Department of Environmental Protection, 1997, Statewide watershed management framework document for the State of New Jersey: Trenton, N.J., New Jersey Department of Environmental Protection, 78 p.

Oblinger-Childress, C.J., Foreman, W.T., Connor, B.F., and Maloney, T.J., 1999, New reporting procedures based on long-term method detection levels and some considerations for interpretation of water-quality data provided by the U.S. Geological Survey National Water Quality Laboratory: U.S. Geological Survey Open-File Report 99-193, 19 p.

Patton, C.J., and Kryskalla, J.R., 2003, Methods of analysis by the U.S. Geological Survey National Water Quality Laboratory, evaluation of alkaline persulfate digestion as an alternative to Kjeldahl digestion for determination of total and dissolved nitrogen and phosphorus in water: U.S. Geological Survey Water-Resources Investigations Report 03-4174, $33 \mathrm{p}$.
Patton, C.J., and Truitt, E.P., 1992, Methods of analysis by the U.S. Geological Survey National Water Quality Laboratory-Determination of total phosphorus by a Kjeldahl digestion method and an automated colorimetric finish that includes dialysis: U.S. Geological Survey Open-File Report 92-146, 39 p.

Patton, C.J., and Truitt, E.P., 2000, Methods of analysis by the U.S. Geological Survey National Water Quality Laboratory-Determination of ammonium plus organic nitrogen by a Kjeldahl digestion method and an automated photometric finish that includes digest cleanup by gas diffusion: U.S. Geological Survey Open-File Report 00-170, 31 p.

Rantz, S. E., and others, 1982, Measurement and computation of streamflow, Volumes 1 and 2: U.S. Geological Survey Water-Supply Paper 2175, $631 \mathrm{p}$.

Runkel, R.L., Crawford, C.G., and Cohn, T.A., 2004, Load estimator (LOADEST) - a FORTRAN program for estimating constituent loads in streams and rivers: U.S. Geological Survey Techniques and Methods, book 4, chap. A5, 69 p.

SAS Institute, Inc., 1999a, The univariate procedure: Cary, N.C., SAS Procedures Guide, Version 8, v. 2, p. 1317-1454.

SAS Institute, Inc., 1999b, The lifetest procedure: Cary, N.C., SAS/STAT User's Guide, Version 8, v. 2, p. 1797-1851.

Schertz, T.L., Alexander, R.B, and Ohe, D.J., 1991, The computer program EStimate TREND (ESTREND), a system for the detection of trends in water-quality data: U.S. Geological Survey Water-Resources Investigations Report 91-4040, $63 \mathrm{p}$.

Slack, J.R., Lorenz, D.L., and others, 2003, USGS library for S-PLUS for Windows-Release 2.1: U.S. Geological Survey Open-File Report 03-357.

Sprague, L.A., Mueller, D.K., Schwarz, G.E., and Lorenz, D.L., 2009, Nutrient trends in streams and rivers of the United States, 1993-2003: U.S. Geological Survey Scientific Investigations Report 2008-5202, 196 p.

U.S. Environmental Protection Agency, 1997, Method 440.0Determination of carbon and nitrogen in sediments and particulates of estuarine/coastal waters using elemental analysis, Revision 1.4: Cincinnati, Ohio, National Exposure Research Laboratory, Office of Research and Development, $10 \mathrm{p}$.

U.S. Geological Survey, variously dated, National field manual for the collection of water-quality data: U.S. Geological Survey Techniques of Water-Resources Investigations, book 9 , chaps. A1-A9, variously paginated (available online at http://pubs.water.usgs.gov/twri9A) .

Watt, M.K., 2000, A hydrologic primer for New Jersey watershed management: U.S. Geological Survey WaterResources Investigations Report 2000-4140, 108 p. 
Table 4. Summary statistics for dissolved oxygen at water-quality stations on New Jersey streams, water years 1998-2007.

[n.a., not applicable]

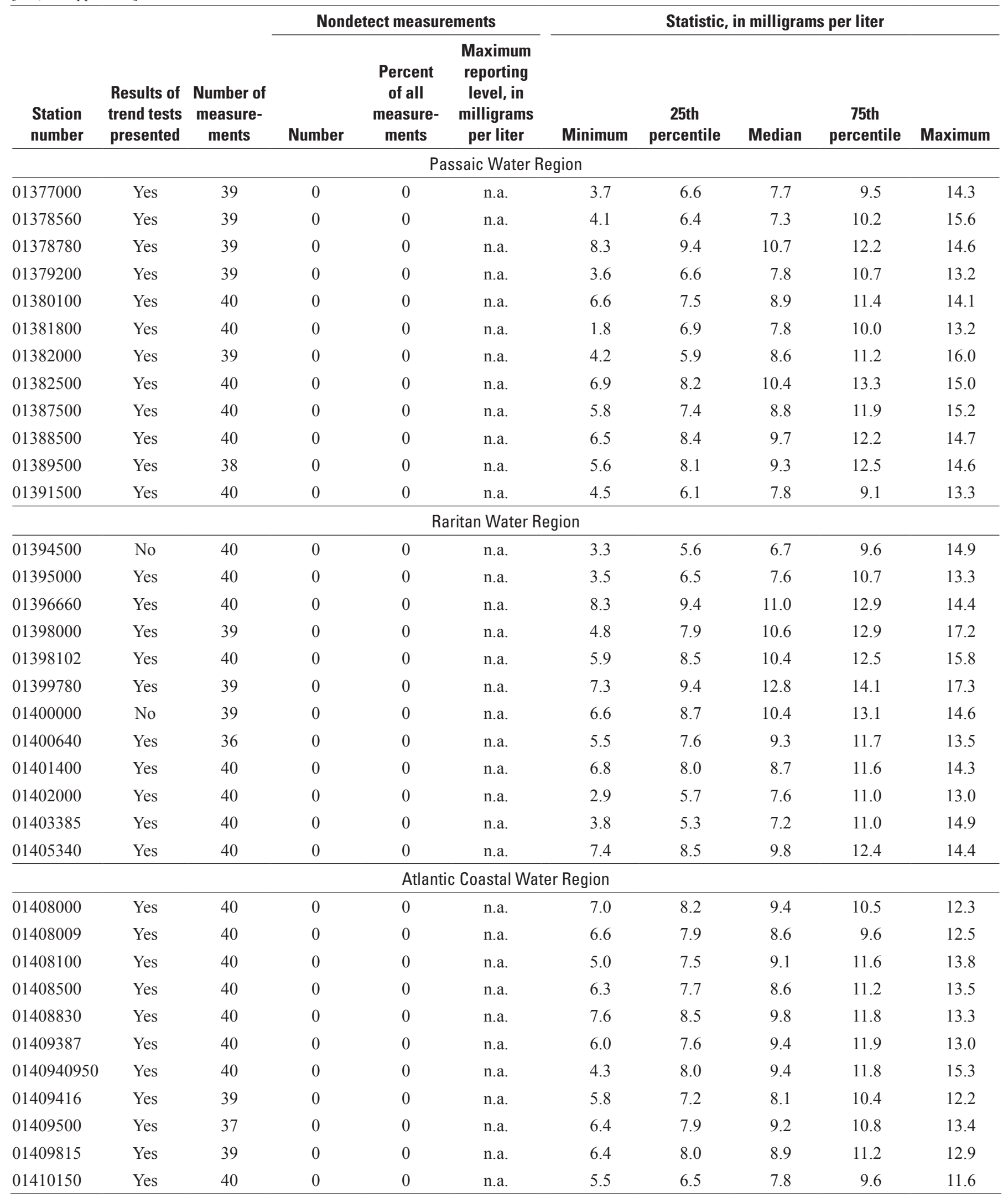


Table 4. Summary statistics for dissolved oxygen at water-quality stations on New Jersey streams, water years 1998-2007.-Continued

\begin{tabular}{|c|c|c|c|c|c|c|c|c|c|c|}
\hline $\begin{array}{l}\text { Station } \\
\text { number }\end{array}$ & $\begin{array}{c}\text { Results of } \\
\text { trend tests } \\
\text { presented }\end{array}$ & $\begin{array}{c}\text { Number of } \\
\text { measure- } \\
\text { ments }\end{array}$ & \multicolumn{3}{|c|}{ Nondetect measurements } & \multicolumn{5}{|c|}{ Statistic, in milligrams per liter } \\
\hline \multicolumn{11}{|c|}{ Atlantic Coastal Water Region } \\
\hline 01411110 & Yes & 40 & 0 & 0 & n.a. & 7.3 & 8.2 & 9.0 & 11.4 & 13.2 \\
\hline 01411196 & Yes & 40 & 0 & 0 & n.a. & 6.1 & 7.5 & 8.2 & 10.0 & 12.0 \\
\hline 01411400 & Yes & 40 & 0 & 0 & n.a. & 2.9 & 5.3 & 8.0 & 9.6 & 12.6 \\
\hline 01411444 & Yes & 35 & 0 & 0 & n.a. & 2.8 & 6.5 & 8.8 & 10.4 & 12.2 \\
\hline \multicolumn{11}{|c|}{ Upper Delaware Water Region } \\
\hline 01367800 & Yes & 34 & 0 & 0 & n.a. & 8.0 & 9.3 & 10.7 & 13.2 & 14.4 \\
\hline 01368820 & Yes & 38 & 0 & 0 & n.a. & 3.6 & 7.3 & 9.7 & 12.3 & 14.3 \\
\hline 01438500 & Yes & 40 & 0 & 0 & n.a. & 6.9 & 8.5 & 9.9 & 12.0 & 14.3 \\
\hline 01440000 & No & 40 & 0 & 0 & n.a. & 6.2 & 9.3 & 10.9 & 12.7 & 15.2 \\
\hline 01442760 & Yes & 39 & 0 & 0 & n.a. & 8.5 & 9.7 & 11.3 & 12.6 & 14.9 \\
\hline 01443000 & Yes & 39 & 0 & 0 & n.a. & 7.4 & 8.3 & 11.1 & 13.7 & 15.8 \\
\hline 01443500 & Yes & 40 & 0 & 0 & n.a. & 6.2 & 8.7 & 10.5 & 13.1 & 16.2 \\
\hline 01446400 & Yes & 40 & 0 & 0 & n.a. & 8.6 & 10.0 & 11.2 & 13.5 & 17.3 \\
\hline 01457400 & Yes & 40 & 0 & 0 & n.a. & 8.3 & 9.5 & 11.0 & 13.4 & 15.5 \\
\hline \multicolumn{11}{|c|}{ Lower Delaware Water Region } \\
\hline 01411466 & Yes & 38 & 0 & 0 & n.a. & 3.8 & 6.1 & 7.5 & 9.4 & 12.2 \\
\hline 01411500 & No & 36 & 0 & 0 & n.a. & 5.8 & 7.1 & 8.3 & 10.4 & 12.8 \\
\hline 01411955 & Yes & 40 & 0 & 0 & n.a. & 5.6 & 7.6 & 8.8 & 10.2 & 12.6 \\
\hline 01412800 & Yes & 38 & 0 & 0 & n.a. & 6.4 & 7.8 & 9.2 & 10.8 & 14.1 \\
\hline 01464504 & Yes & 39 & 0 & 0 & n.a. & 6.7 & 7.9 & 9.3 & 11.7 & 14.8 \\
\hline 01464515 & Yes & 40 & 0 & 0 & n.a. & 1.9 & 6.1 & 8.9 & 11.9 & 14.3 \\
\hline 01465893 & Yes & 38 & 0 & 0 & n.a. & 5.8 & 7.3 & 8.7 & 11.2 & 12.9 \\
\hline 01466500 & Yes & 40 & 0 & 0 & n.a. & 2.0 & 2.7 & 3.4 & 6.2 & 9.4 \\
\hline 01467005 & Yes & 39 & 0 & 0 & n.a. & 6.4 & 8.4 & 9.9 & 12.1 & 14.2 \\
\hline 01467150 & Yes & 39 & 0 & 0 & n.a. & 4.6 & 6.8 & 7.9 & 10.5 & 12.7 \\
\hline 01467359 & Yes & 40 & 0 & 0 & n.a. & 3.5 & 5.9 & 8.2 & 11.2 & 13.6 \\
\hline 01477120 & Yes & 40 & 0 & 0 & n.a. & 5.3 & 7.6 & 8.8 & 11.4 & 13.2 \\
\hline 01482500 & Yes & 40 & 0 & 0 & n.a. & 5.2 & 8.0 & 9.5 & 11.8 & 15.8 \\
\hline
\end{tabular}



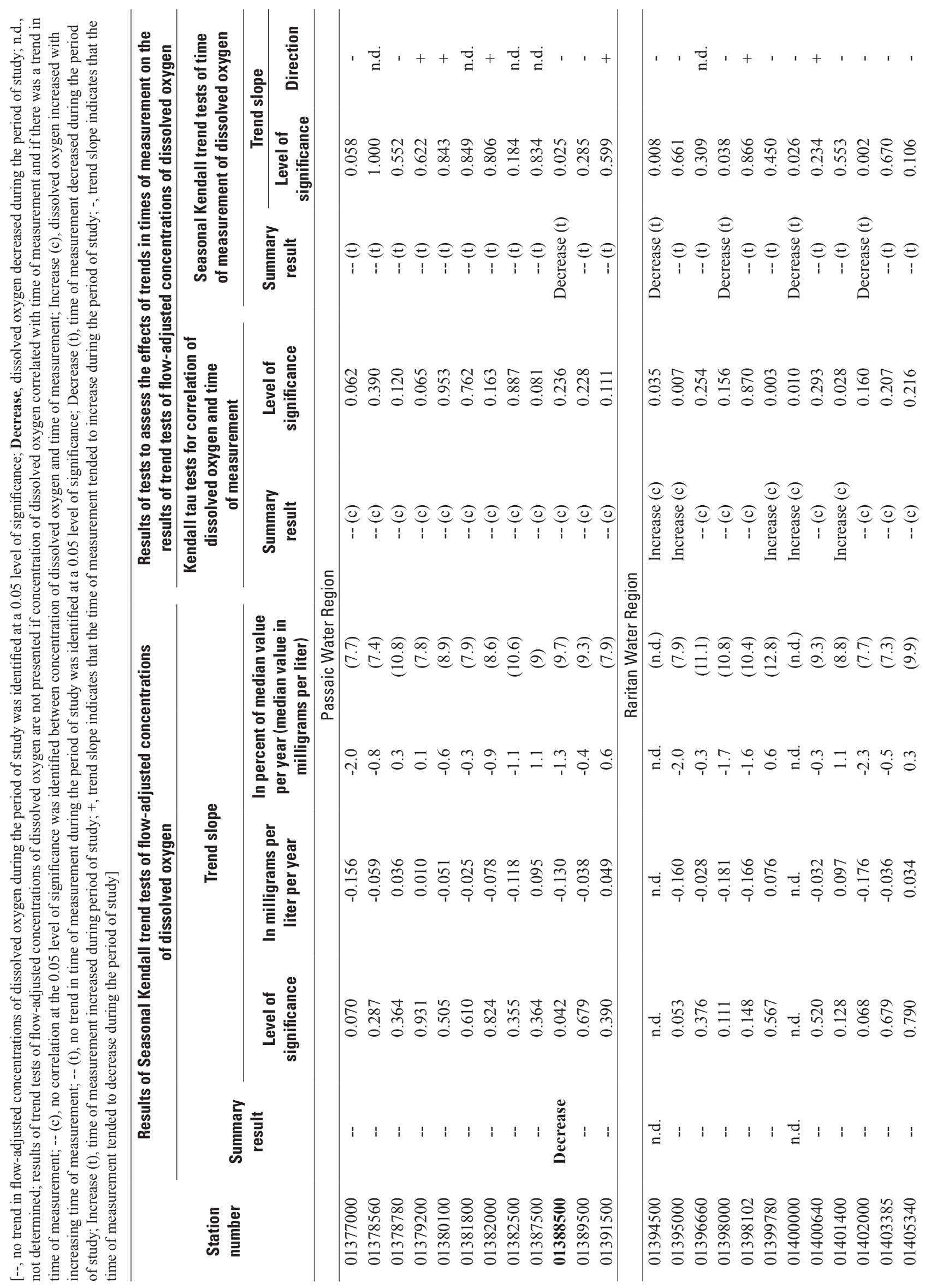


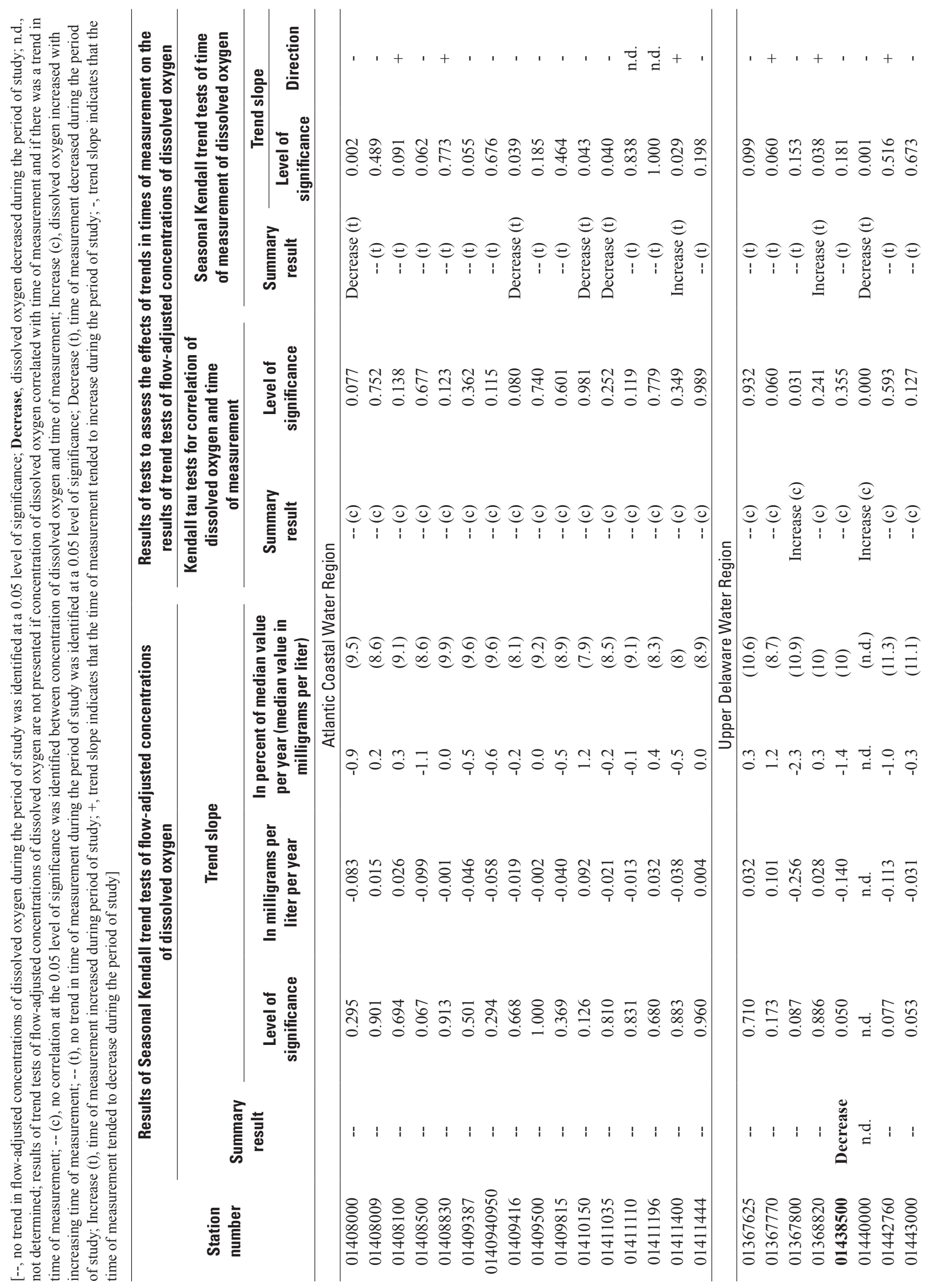




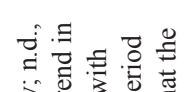

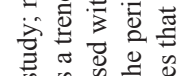

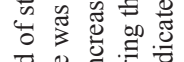

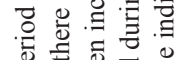

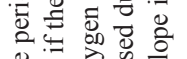

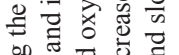

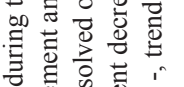

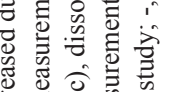

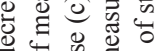

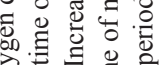

ช.

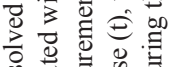

品

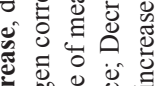

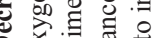

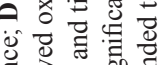

政步

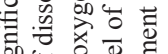

的若

능

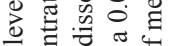

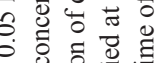

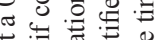

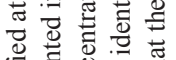

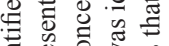

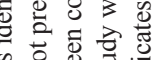

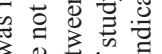

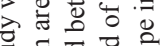

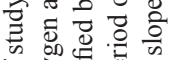

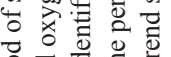

응

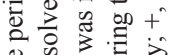

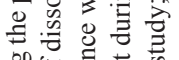

on

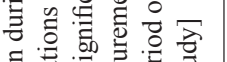

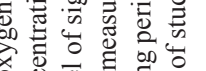

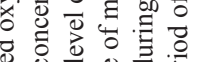

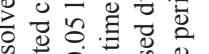

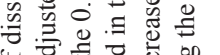

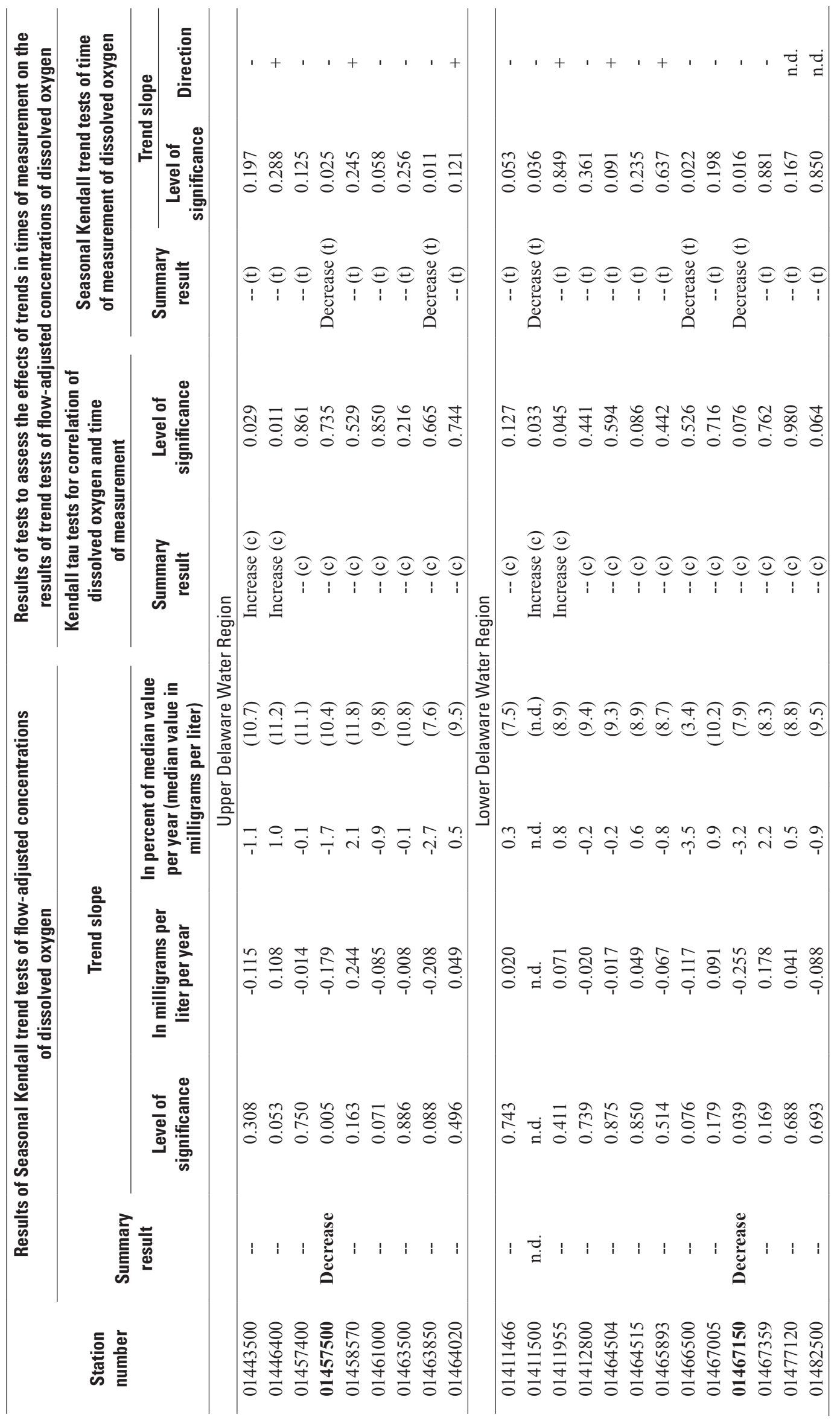

๓ึ่

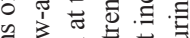

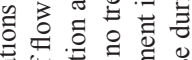

넝

ơ

唡

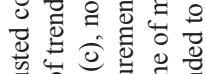

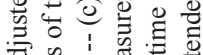

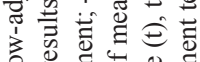

要

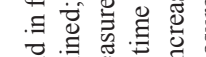

을 ᄋ 
Table 5

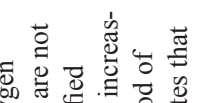

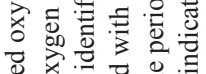

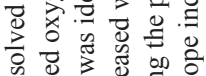

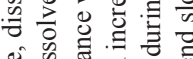

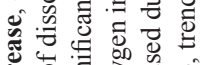

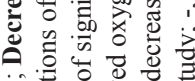

政

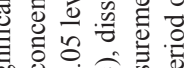

贸过过

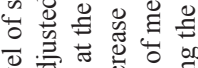

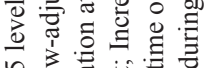

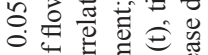

出

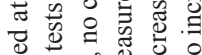

प0

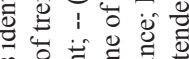

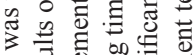

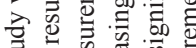

फ़

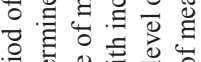

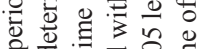

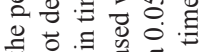

on

责记

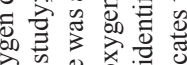

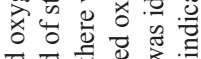

o 0

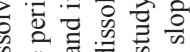

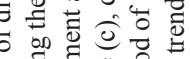

白

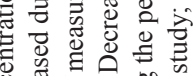

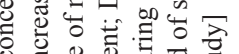

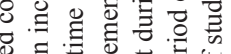

密品

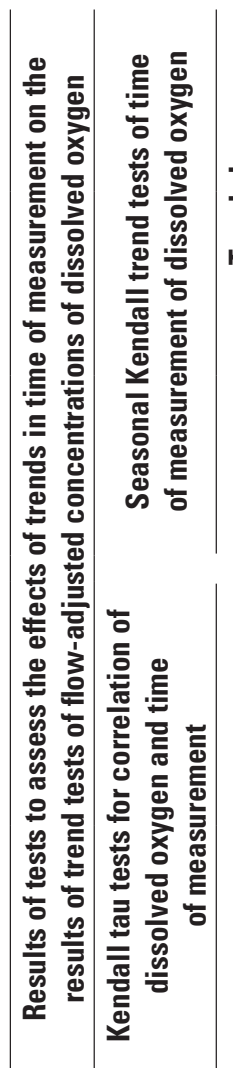

$\mid$

:

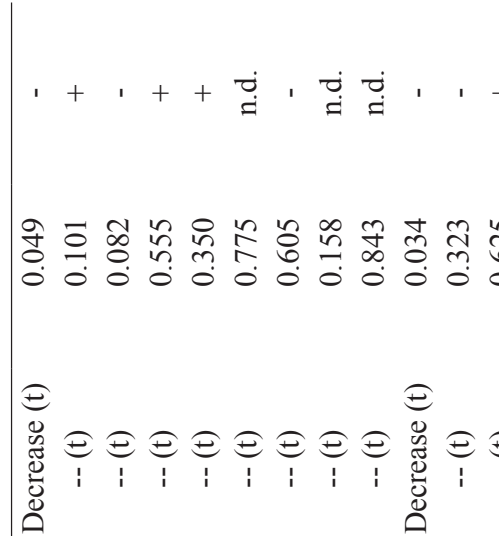

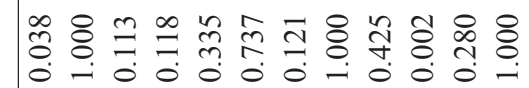

흘

उ $\exists$ 要

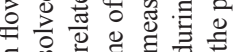

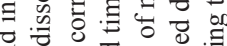

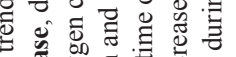

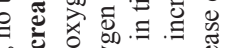

约

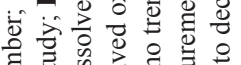

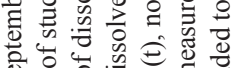

Q 0 o

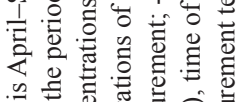

을

เทं 命

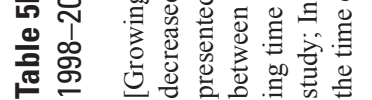

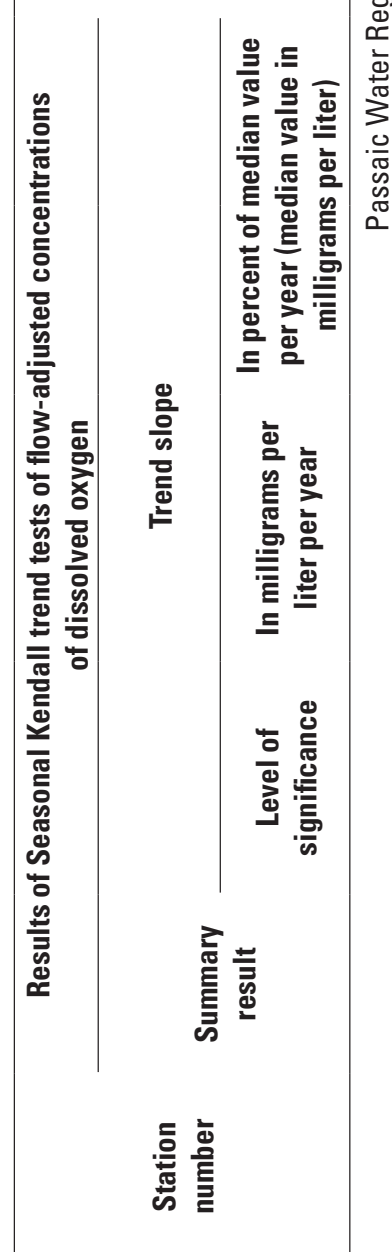

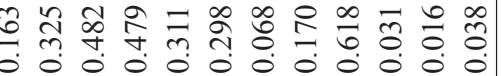

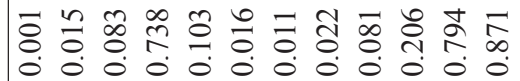

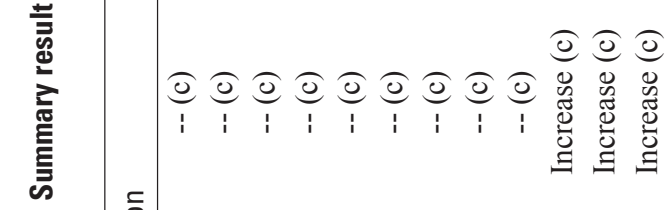

듬

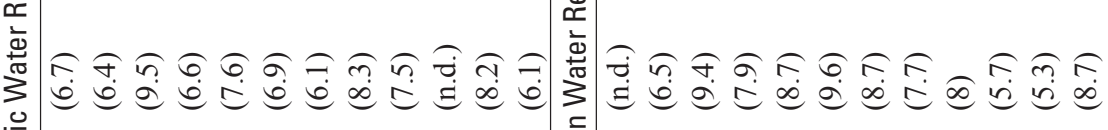

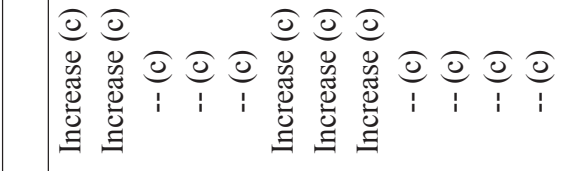

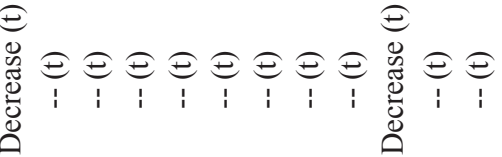

(3)

त̄

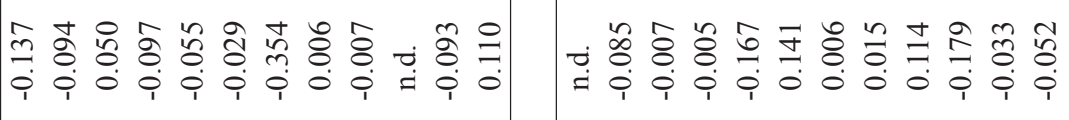

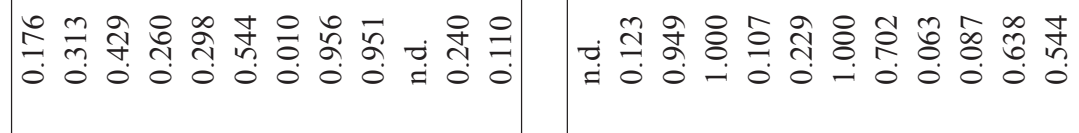

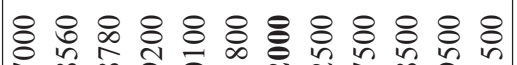

용ㅇㅇㅇㅇㅇㅇㅇㅇ \& $\&$

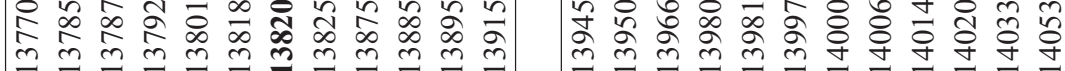

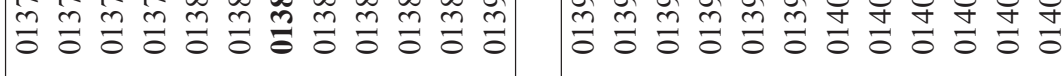



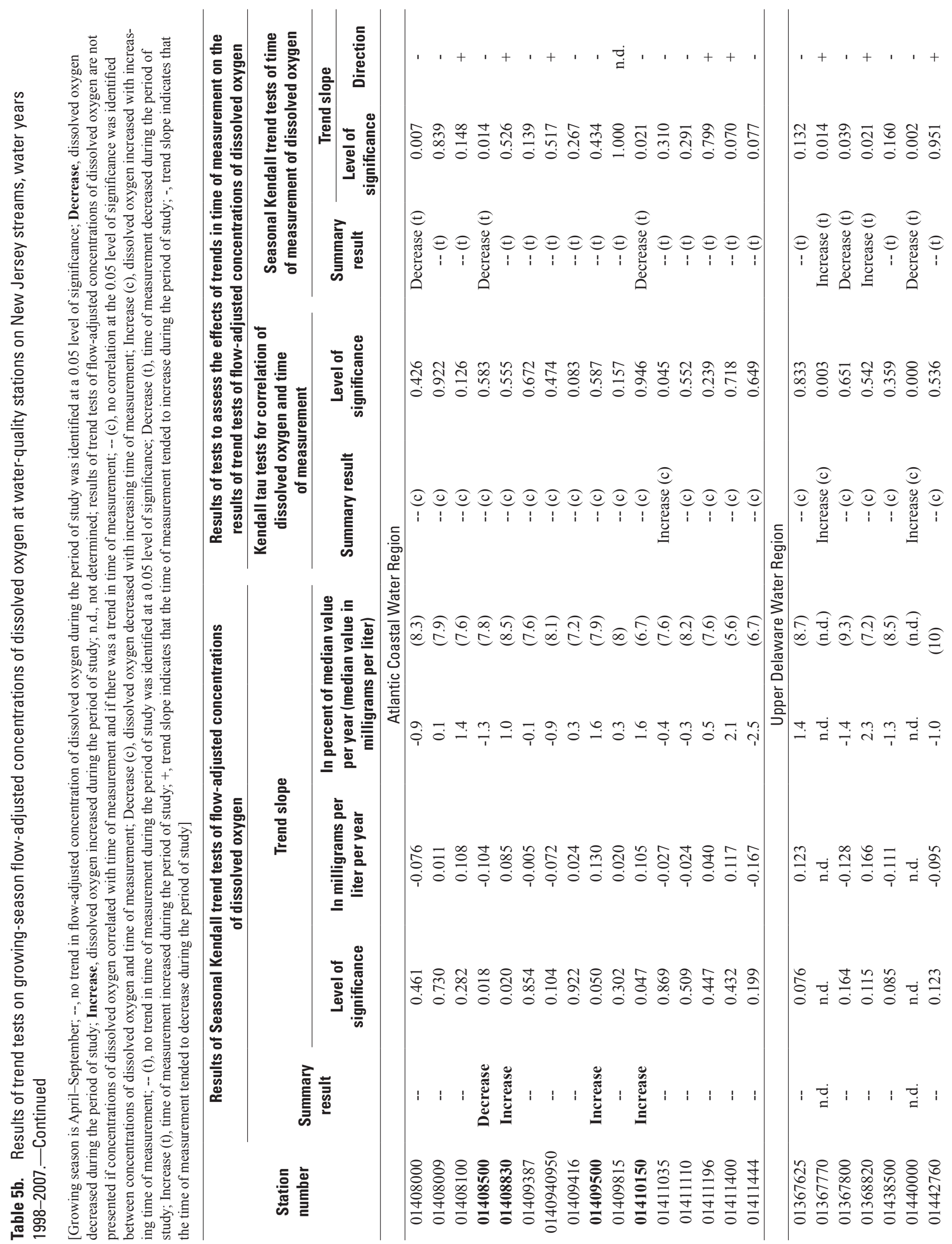
Table 5

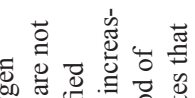

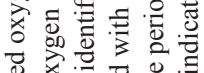

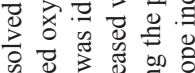

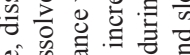

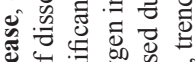

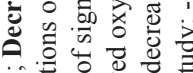

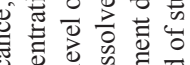

至

क力

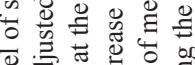

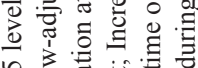

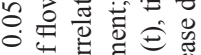

拜

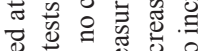

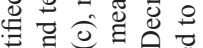

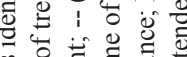

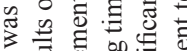

तो

क⿺辶大

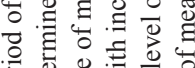

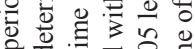

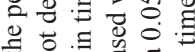

on

可导导导焉

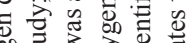

क

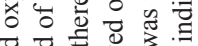

웡

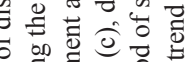

on 0

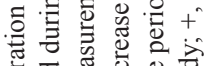

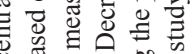

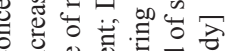

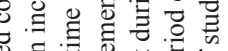

岛品

क्षे

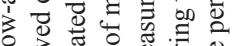

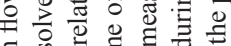

号 0 .

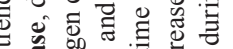

呵

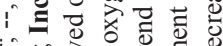

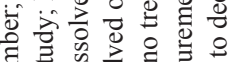

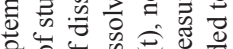

잉

家.

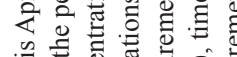

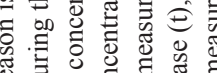

เं

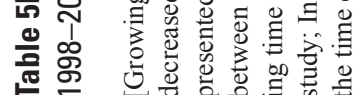

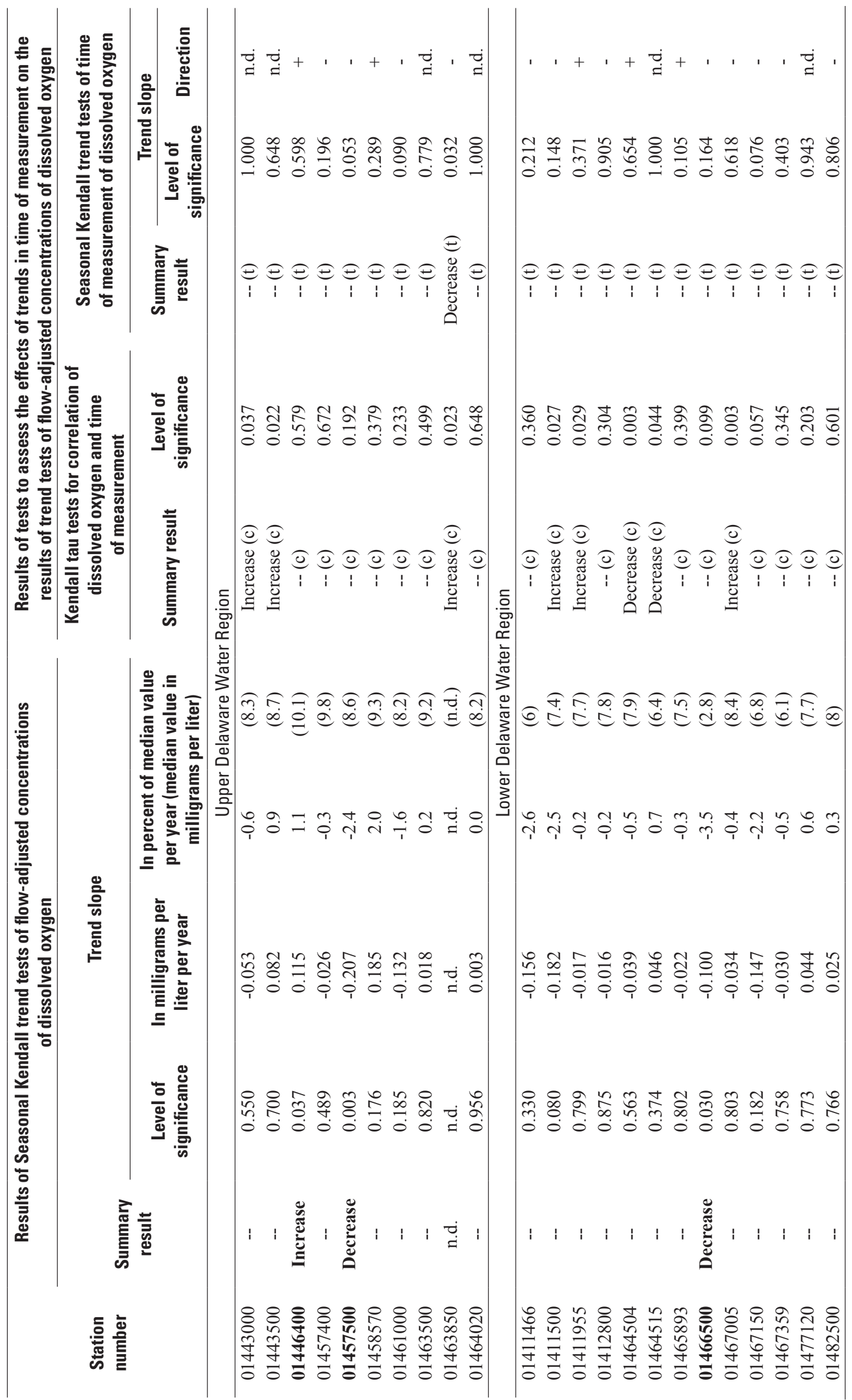


Table 5c. Results of trend tests on flow-adjusted concentrations of year-round and growing-season dissolved oxygen at selected water-quality stations on New Jersey streams, water years 1998-2007.

[Stations included are those at which a trend was identified in either year-round or growing-season concentrations at a 0.05 level of significance; --, no trend in flow-adjusted concentrations of dissolved oxygen during the period of study was identified at a 0.05 level of significance; Decrease, concentrations of dissolved oxygen decreased during the period of study; Increase, concentrations of dissolved oxygen increased during the period of study; n.d., not determined]

\begin{tabular}{|c|c|c|c|}
\hline \multirow{2}{*}{$\begin{array}{l}\text { Station } \\
\text { number }\end{array}$} & \multirow[b]{2}{*}{ Station name } & \multicolumn{2}{|c|}{ Results of trend tests in flow-adjusted concentrations of dissolved oxygen } \\
\hline & & Year-round measurements & $\begin{array}{c}\text { Growing-season measurements } \\
\text { (April-September) }\end{array}$ \\
\hline 01382000 & Passaic River at Two Bridges, N.J. & -- & Decrease \\
\hline 01388500 & Pompton River at Pompton Plains, N.J. & Decrease & n.d. \\
\hline \multicolumn{4}{|c|}{ Raritan Water Region } \\
\hline \multicolumn{4}{|c|}{ (none) } \\
\hline \multicolumn{4}{|c|}{ Atlantic Coastal Water Region } \\
\hline 01408500 & Toms River near Toms River, N.J. & -- & Decrease \\
\hline 01408830 & Cedar Creek at Cedar Crest, N.J. & -- & Increase \\
\hline 01409500 & Batsto River at Batsto, N.J. & -- & Increase \\
\hline 01446400 & Pequest River at Belvidere, N.J. & -- & Increase \\
\hline 01457500 & Delaware River at Riegelsville, N.J. & Decrease & Decrease \\
\hline \multicolumn{4}{|c|}{ Lower Delaware Water Region } \\
\hline 01466500 & McDonalds Branch in Byrne State Forest, N.J. & -- & Decrease \\
\hline 01467150 & Cooper River at Haddonfield, N.J. & Decrease & -- \\
\hline
\end{tabular}


Table 6. Summary statistics for $\mathrm{pH}$ at water-quality stations on New Jersey streams, water years 1998-2007.

[n.a., not applicable]

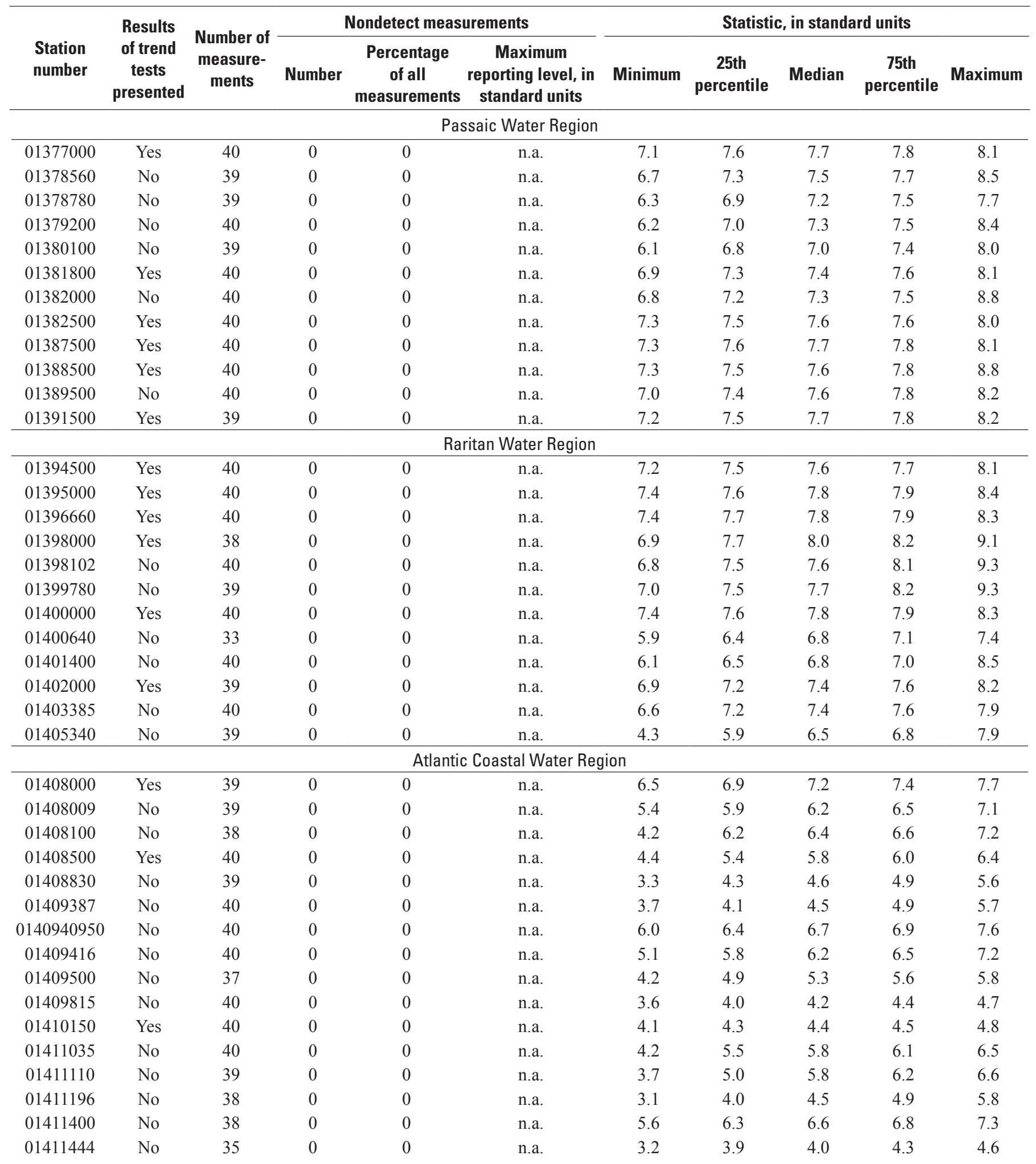


Table 6. Summary statistics for $\mathrm{pH}$ at water-quality stations on New Jersey streams, water years 1998-2007.-Continued [n.a., not applicable]

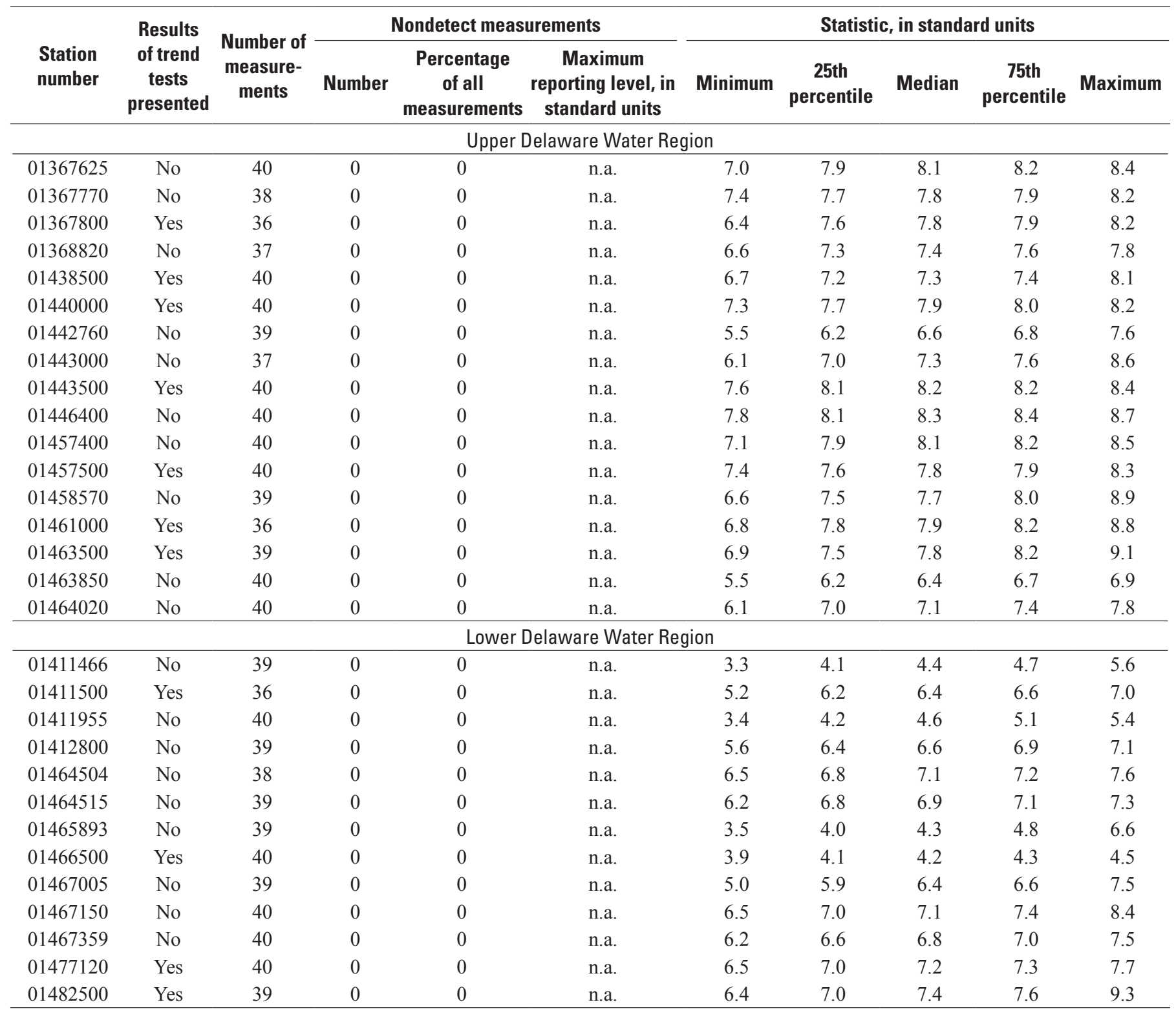


Table 7

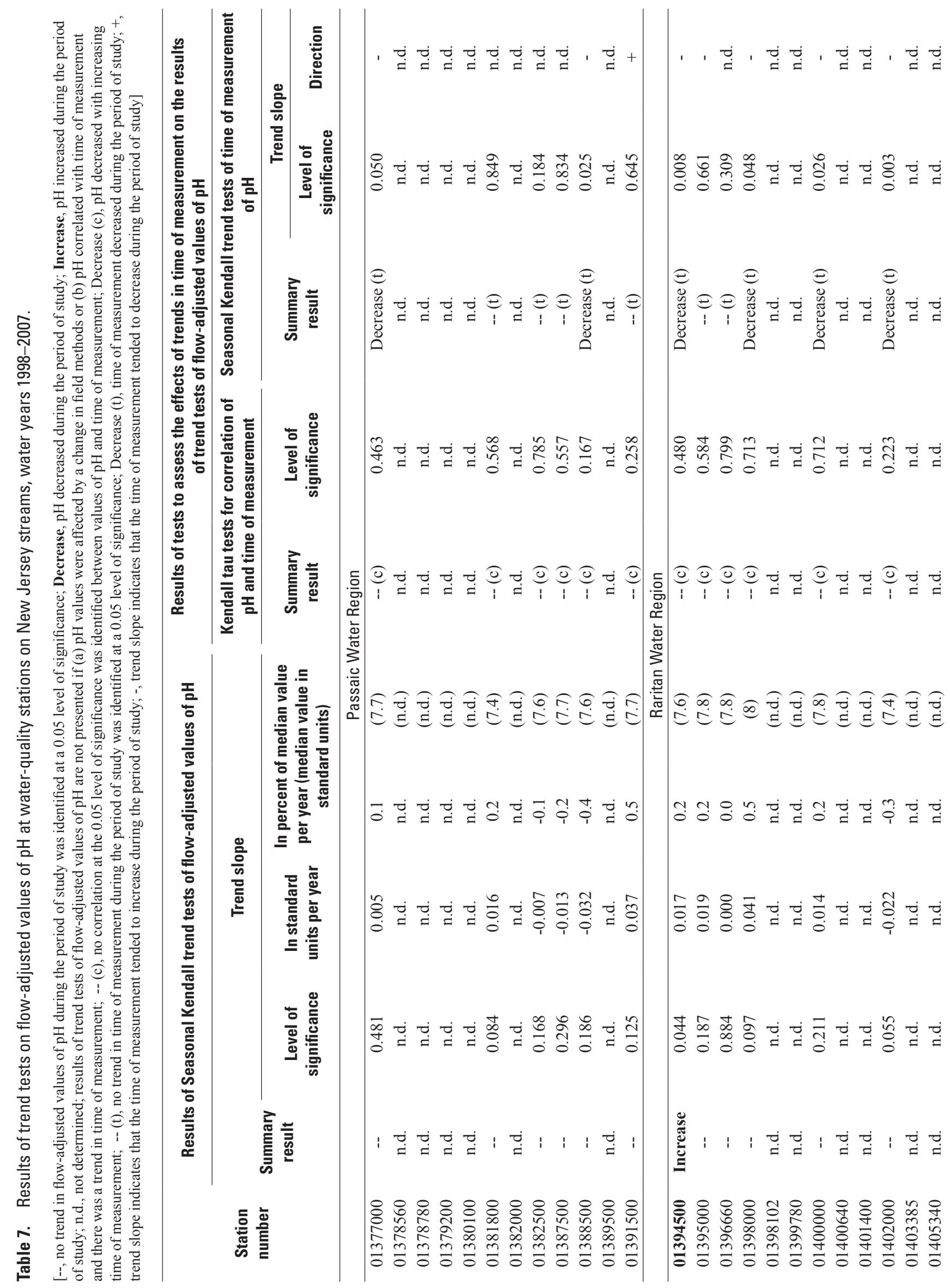




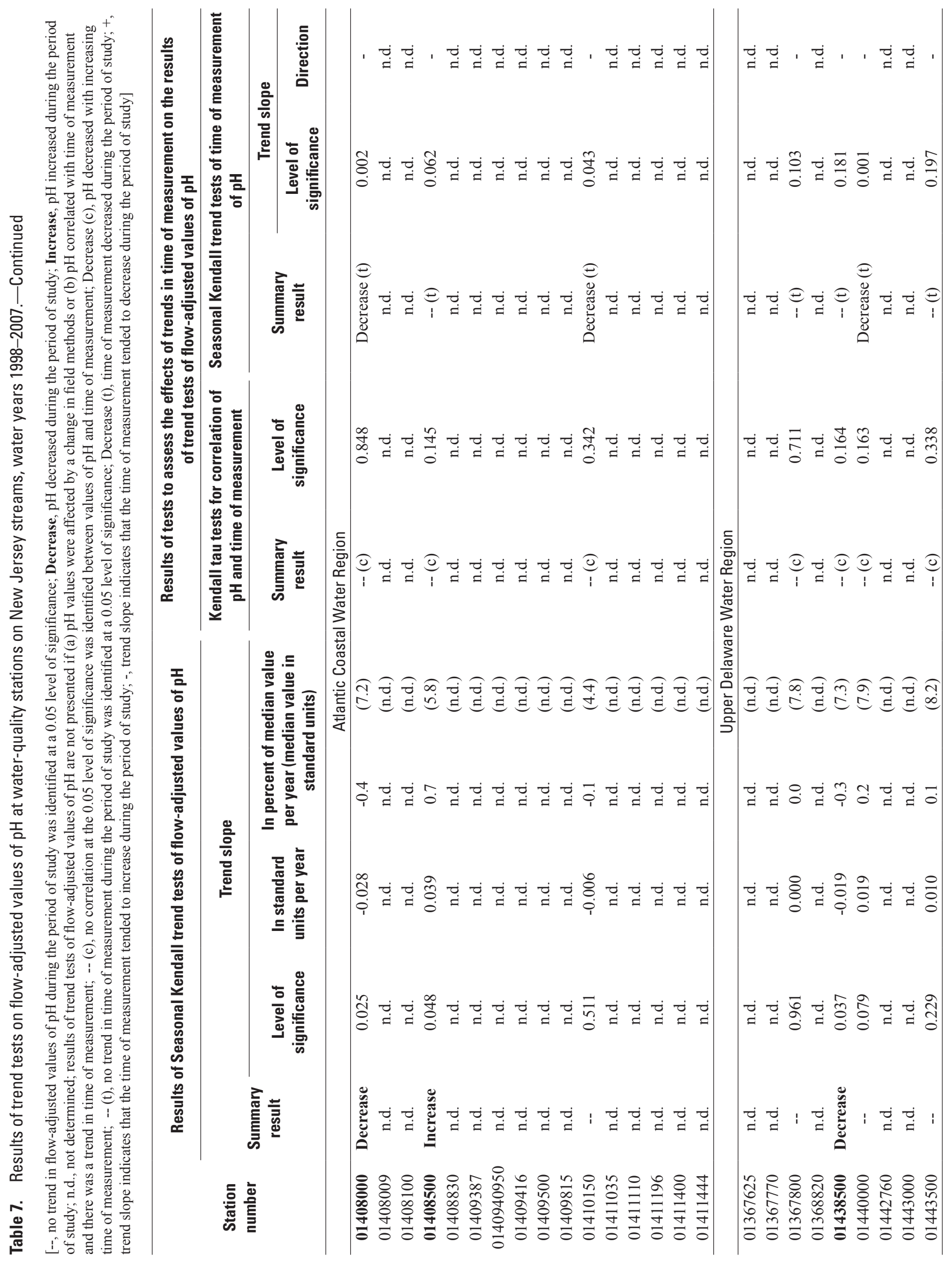




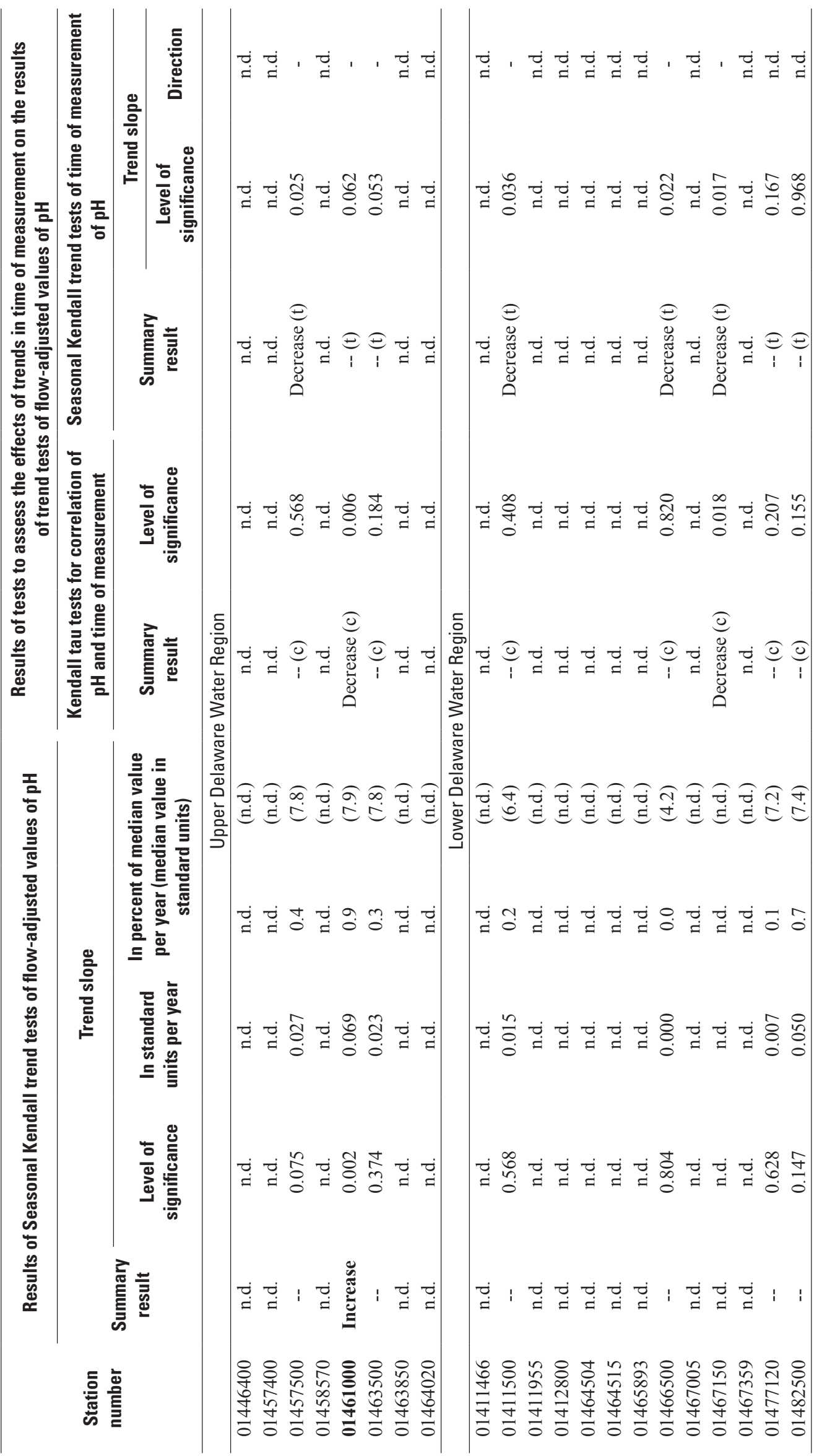


Table 8. Summary statistics for total dissolved solids at water-quality stations on New Jersey streams, water years 1998-2007.

[n.a., not applicable; <, less than]

\begin{tabular}{|c|c|c|c|c|c|c|c|c|c|c|}
\hline \multirow[b]{2}{*}{$\begin{array}{l}\text { Station } \\
\text { number }\end{array}$} & \multirow[b]{2}{*}{$\begin{array}{c}\text { Results of } \\
\text { trend tests } \\
\text { presented }\end{array}$} & \multirow[b]{2}{*}{$\begin{array}{c}\text { Number of } \\
\text { measure- } \\
\text { ments }\end{array}$} & \multicolumn{3}{|c|}{ Nondetect measurements } & \multicolumn{5}{|c|}{ Statistic, in milligrams per liter } \\
\hline & & & Number & $\begin{array}{c}\text { Percentage } \\
\text { of all } \\
\text { measurements }\end{array}$ & $\begin{array}{c}\text { Maximum } \\
\text { reporting level, } \\
\text { in milligrams } \\
\text { per liter }\end{array}$ & Minimum & $\begin{array}{c}\text { 25th } \\
\text { percentile }\end{array}$ & Median & $\begin{array}{c}\text { 75th } \\
\text { percentile }\end{array}$ & Maximum \\
\hline \multicolumn{11}{|c|}{ Passaic Water Region } \\
\hline 01377000 & Yes & 40 & 0 & 0 & n.a. & 122 & 229 & 253 & 288 & 425 \\
\hline 01379200 & Yes & 40 & 0 & 0 & n.a. & 140 & 269 & 332 & 387 & 1,040 \\
\hline 01380100 & Yes & 40 & 0 & 0 & n.a. & 78 & 106 & 122 & 136 & 168 \\
\hline 01381800 & Yes & 40 & 0 & 0 & n.a. & 136 & 274 & 331 & 387 & 755 \\
\hline 01382000 & Yes & 40 & 0 & 0 & n.a. & 141 & 252 & 314 & 389 & 780 \\
\hline 01382500 & Yes & 39 & 0 & 0 & n.a. & 78 & 94 & 122 & 139 & 218 \\
\hline 01391500 & Yes & 39 & 0 & 0 & n.a. & 199 & 408 & 449 & 500 & 819 \\
\hline \multicolumn{11}{|c|}{ Raritan Water Region } \\
\hline 01394500 & Yes & 40 & 0 & 0 & n.a. & 123 & 365 & 398 & 460 & 2,296 \\
\hline 01395000 & Yes & 40 & 0 & 0 & n.a. & 156 & 276 & 344 & 406 & 651 \\
\hline 01396660 & Yes & 40 & 0 & 0 & n.a. & 113 & 139 & 149 & 159 & 200 \\
\hline 01398000 & Yes & 38 & 0 & 0 & n.a. & 126 & 168 & 192 & 224 & 688 \\
\hline 01398102 & Yes & 40 & 0 & 0 & n.a. & 114 & 146 & 170 & 181 & 279 \\
\hline 01399780 & Yes & 39 & 0 & 0 & n.a. & 72 & 129 & 152 & 172 & 234 \\
\hline 01400000 & Yes & 40 & 0 & 0 & n.a. & 101 & 147 & 167 & 187 & 293 \\
\hline 01400640 & Yes & 36 & 0 & 0 & n.a. & 117 & 147 & 162 & 183 & 237 \\
\hline \multicolumn{11}{|c|}{ Atlantic Coastal Water Region } \\
\hline 01408100 & Yes & 40 & 0 & 0 & n.a. & 47 & 88 & 101 & 114 & 192 \\
\hline 01408500 & Yes & 40 & 0 & 0 & n.a. & 45 & 59 & 65 & 71 & 85 \\
\hline 01408830 & Yes & 40 & 0 & 0 & n.a. & 15 & 21 & 24 & 27 & 40 \\
\hline 01409387 & Yes & 40 & 0 & 0 & n.a. & 16 & 30 & 34 & 40 & 59 \\
\hline 0140940950 & Yes & 40 & 0 & 0 & n.a. & 36 & 46 & 51 & 59 & 79 \\
\hline 01409416 & Yes & 40 & 0 & 0 & n.a. & 53 & 76 & 80 & 87 & 105 \\
\hline 01409500 & Yes & 37 & 0 & 0 & n.a. & 19 & 31 & 36 & 42 & 51 \\
\hline 01409815 & Yes & 40 & 0 & 0 & n.a. & 20 & 26 & 28 & 31 & 41 \\
\hline 01410150 & Yes & 40 & 1 & 3 & 10 & $<10$ & 25 & 29 & 34 & 52 \\
\hline 01411035 & Yes & 40 & 0 & 0 & n.a. & 36 & 46 & 50 & 54 & 70 \\
\hline 01411110 & Yes & 40 & 0 & 0 & n.a. & 25 & 44 & 50 & 59 & 73 \\
\hline 01411196 & Yes & 40 & 0 & 0 & n.a. & 32 & 40 & 47 & 55 & 93 \\
\hline 01411400 & Yes & 40 & 0 & 0 & n.a. & 81 & 106 & 122 & 134 & 213 \\
\hline 01411444 & Yes & 36 & 0 & 0 & n.a. & 23 & 39 & 41 & 49 & 84 \\
\hline
\end{tabular}


Table 8. Summary statistics for total dissolved solids at water-quality stations on New Jersey streams, water years 1998-2007.-Continued

[n.a., not applicable; $<$, less than]

\begin{tabular}{|c|c|c|c|c|c|c|c|c|c|c|}
\hline \multirow[b]{2}{*}{$\begin{array}{l}\text { Station } \\
\text { number }\end{array}$} & \multirow[b]{2}{*}{$\begin{array}{c}\text { Results of } \\
\text { trend tests } \\
\text { presented }\end{array}$} & \multirow[b]{2}{*}{$\begin{array}{c}\text { Number of } \\
\text { measure- } \\
\text { ments }\end{array}$} & \multicolumn{3}{|c|}{ Nondetect measurements } & \multicolumn{5}{|c|}{ Statistic, in milligrams per liter } \\
\hline & & & Number & $\begin{array}{c}\text { Percentage } \\
\text { of all } \\
\text { measurements }\end{array}$ & $\begin{array}{c}\text { Maximum } \\
\text { reporting level, } \\
\text { in milligrams } \\
\text { per liter }\end{array}$ & Minimum & $\begin{array}{c}\text { 25th } \\
\text { percentile }\end{array}$ & Median & $\begin{array}{c}\text { 75th } \\
\text { percentile }\end{array}$ & Maximum \\
\hline \multicolumn{11}{|c|}{ Upper Delaware Water Region } \\
\hline 01367625 & Yes & 40 & 0 & 0 & n.a. & 292 & 343 & 360 & 405 & 480 \\
\hline 01368820 & Yes & 39 & 0 & 0 & n.a. & 12 & 128 & 140 & 154 & 179 \\
\hline 01438500 & Yes & 40 & 0 & 0 & n.a. & 37 & 46 & 52 & 58 & 71 \\
\hline 01440000 & Yes & 39 & 0 & 0 & n.a. & 57 & 100 & 110 & 129 & 176 \\
\hline 01442760 & Yes & 38 & 0 & 0 & n.a. & 18 & 23 & 25 & 27 & 31 \\
\hline 01443000 & Yes & 39 & 0 & 0 & n.a. & 47 & 50 & 57 & 63 & 75 \\
\hline 01457500 & Yes & 40 & 0 & 0 & n.a. & 68 & 91 & 110 & 122 & 163 \\
\hline 01458570 & Yes & 40 & 0 & 0 & n.a. & 89 & 105 & 112 & 117 & 136 \\
\hline 01461000 & Yes & 40 & 0 & 0 & n.a. & 61 & 94 & 118 & 129 & 148 \\
\hline 01463500 & Yes & 39 & 0 & 0 & n.a. & 67 & 90 & 114 & 124 & 149 \\
\hline 01463850 & Yes & 40 & 0 & 0 & n.a. & 68 & 100 & 117 & 138 & 285 \\
\hline 01464020 & Yes & 40 & 0 & 0 & n.a. & 101 & 176 & 215 & 248 & 453 \\
\hline \multicolumn{11}{|c|}{ Lower Delaware Water Region } \\
\hline 01411466 & Yes & 39 & 0 & 0 & n.a. & 29 & 39 & 46 & 56 & 74 \\
\hline 01411500 & Yes & 36 & 0 & 0 & n.a. & 52 & 64 & 70 & 80 & 88 \\
\hline 01411955 & Yes & 40 & 0 & 0 & n.a. & 15 & 21 & 25 & 30 & 56 \\
\hline 01467359 & Yes & 40 & 0 & 0 & n.a. & 58 & 102 & 112 & 126 & 406 \\
\hline 01477120 & Yes & 40 & 0 & 0 & n.a. & 105 & 129 & 137 & 145 & 223 \\
\hline 01482500 & Yes & 40 & 0 & 0 & n.a. & 117 & 155 & 160 & 168 & 182 \\
\hline
\end{tabular}


Table 9. Results of trend tests on flow-adjusted concentrations of total dissolved solids at water-quality stations on New Jersey streams, water years 1998-2007.

[--, no trend in flow-adjusted concentrations of total dissolved solids during the period of study was identified at a 0.05 level of significance; Increase, concentrations of total dissolved solids increased during the period of study]

\begin{tabular}{|c|c|c|c|c|c|}
\hline \multirow{3}{*}{$\begin{array}{l}\text { Station } \\
\text { number }\end{array}$} & \multicolumn{5}{|c|}{$\begin{array}{l}\text { Results of Seasonal Kendall trend tests of } \\
\text { flow-adjusted concentrations of total dissolved solids }\end{array}$} \\
\hline & \multirow[b]{2}{*}{$\begin{array}{l}\text { Summary } \\
\text { result }\end{array}$} & \multicolumn{4}{|c|}{ Trend slope } \\
\hline & & $\begin{array}{l}\text { Level of } \\
\text { signifi- } \\
\text { cance }\end{array}$ & $\begin{array}{l}\text { In milligrams } \\
\text { per liter } \\
\text { per year }\end{array}$ & \multicolumn{2}{|c|}{$\begin{array}{l}\text { In percent of median } \\
\text { value per year } \\
\text { (median value in } \\
\text { milligrams per liter) }\end{array}$} \\
\hline \multicolumn{6}{|c|}{ Passaic Water Region } \\
\hline 01377000 & -- & 0.918 & -0.4 & -0.2 & $(253)$ \\
\hline 01378560 & -- & 0.065 & 15.6 & 4.2 & $(369)$ \\
\hline 01378780 & -- & 0.143 & 0.5 & 0.5 & $(90)$ \\
\hline 01379200 & Increase & 0.038 & 8.6 & 2.6 & $(332)$ \\
\hline 01380100 & -- & 0.752 & -0.3 & -0.2 & $(122)$ \\
\hline 01381800 & Increase & 0.014 & 9.6 & 2.9 & $(331)$ \\
\hline 01382000 & -- & 0.330 & 2.0 & 0.6 & $(314)$ \\
\hline 01382500 & -- & 0.368 & 0.7 & 0.6 & $(122)$ \\
\hline 01387500 & -- & 0.078 & 3.7 & 1.5 & $(247)$ \\
\hline 01388500 & -- & 0.409 & 2.4 & 1.0 & $(228)$ \\
\hline 01389500 & -- & 0.125 & 5.6 & 1.9 & $(291)$ \\
\hline 01391500 & Increase & 0.006 & 9.0 & 2.0 & $(449)$ \\
\hline \multicolumn{6}{|c|}{ Raritan Water Region } \\
\hline 01394500 & Increase & 0.020 & 9.9 & 2.5 & $(398)$ \\
\hline 01395000 & Increase & 0.048 & 12.9 & 3.7 & $(344)$ \\
\hline 01396660 & -- & 0.963 & 0.1 & 0.0 & (149) \\
\hline 01398000 & -- & 0.188 & 2.6 & 1.3 & (192) \\
\hline 01398102 & Increase & 0.014 & 2.0 & 1.2 & $(170)$ \\
\hline 01399780 & Increase & 0.033 & 4.3 & 2.8 & $(152)$ \\
\hline 01400000 & Increase & 0.048 & 4.9 & 2.9 & $(167)$ \\
\hline 01400640 & -- & 0.176 & 1.3 & 0.8 & $(162)$ \\
\hline 01401400 & Increase & 0.002 & 8.3 & 5.3 & $(156)$ \\
\hline 01402000 & -- & 0.052 & 5.0 & 2.7 & $(183)$ \\
\hline 01403385 & -- & 0.084 & 6.7 & 2.2 & $(305)$ \\
\hline 01405340 & Increase & 0.002 & 4.8 & 3.8 & $(127)$ \\
\hline \multicolumn{6}{|c|}{ Atlantic Coastal Water Region } \\
\hline 01408000 & Increase & 0.004 & 5.7 & 3.8 & $(150)$ \\
\hline 01408009 & -- & 0.191 & 0.7 & 0.8 & (87) \\
\hline 01408100 & Increase & 0.009 & 3.9 & 3.8 & $(101)$ \\
\hline 01408500 & Increase & 0.003 & 1.4 & 2.2 & $(65)$ \\
\hline 01408830 & -- & 0.706 & 0.1 & 0.5 & $(24)$ \\
\hline 01409387 & -- & 0.141 & 1.1 & 3.1 & (34) \\
\hline 0140940950 & Increase & 0.041 & 1.4 & 2.7 & $(51)$ \\
\hline 01409416 & Increase & 0.040 & 0.9 & 1.2 & $(80)$ \\
\hline 01409500 & -- & 0.404 & 0.4 & 1.1 & $(36)$ \\
\hline 01409815 & -- & 0.836 & 0.2 & 0.6 & $(28)$ \\
\hline 01410150 & Increase & 0.048 & 0.6 & 1.9 & (29) \\
\hline 01411035 & -- & 0.656 & -0.2 & -0.4 & $(50)$ \\
\hline 01411110 & Increase & 0.013 & 1.1 & 2.2 & $(50)$ \\
\hline 01411196 & -- & 0.053 & 1.2 & 2.5 & (47) \\
\hline 01411400 & -- & 0.064 & -1.6 & -1.3 & $(122)$ \\
\hline 01411444 & -- & 0.596 & 0.5 & 1.1 & (42) \\
\hline
\end{tabular}

\begin{tabular}{|c|c|c|c|c|c|}
\hline \multirow{3}{*}{$\begin{array}{l}\text { Station } \\
\text { number }\end{array}$} & \multicolumn{5}{|c|}{$\begin{array}{l}\text { Results of Seasonal Kendall trend tests of } \\
\text { flow-adjusted concentrations of total dissolved solids }\end{array}$} \\
\hline & \multirow[b]{2}{*}{$\begin{array}{c}\text { Summary } \\
\text { result }\end{array}$} & \multicolumn{4}{|c|}{ Trend slope } \\
\hline & & $\begin{array}{c}\text { Level of } \\
\text { signifi- } \\
\text { cance }\end{array}$ & $\begin{array}{c}\text { In milligrams } \\
\text { per liter } \\
\text { per year }\end{array}$ & $\begin{array}{r}\text { In perce } \\
\text { value } \\
\text { (medi } \\
\text { milligra }\end{array}$ & $\begin{array}{l}\text { median } \\
\text { year } \\
\text { lue in } \\
\text { er liter) }\end{array}$ \\
\hline \multicolumn{6}{|c|}{ Upper Delaware Water Region } \\
\hline 01367625 & -- & 0.977 & 0.4 & 0.1 & $(360)$ \\
\hline 01367770 & -- & 0.417 & 1.4 & 0.4 & $(326)$ \\
\hline 01367800 & -- & 0.443 & -1.5 & -0.7 & $(206)$ \\
\hline 01368820 & -- & 0.180 & 1.6 & 1.2 & $(140)$ \\
\hline 01438500 & -- & 0.276 & -0.5 & -0.9 & $(52)$ \\
\hline 01440000 & -- & 0.409 & 0.7 & 0.7 & $(110)$ \\
\hline 01442760 & -- & 0.132 & 0.3 & 1.2 & $(25)$ \\
\hline 01443000 & -- & 0.750 & -0.0 & 0.0 & $(57)$ \\
\hline 01443500 & -- & 0.842 & -0.4 & -0.2 & $(249)$ \\
\hline 01446400 & -- & 0.701 & 0.5 & 0.2 & $(291)$ \\
\hline 01457400 & -- & 0.187 & 1.1 & 0.5 & $(234)$ \\
\hline 01457500 & -- & 0.196 & 1.3 & 1.2 & $(110)$ \\
\hline 01458570 & -- & 0.891 & -0.2 & -0.2 & $(112)$ \\
\hline 01461000 & -- & 0.635 & 0.1 & 0.1 & $(118)$ \\
\hline 01463500 & -- & 0.653 & -0.7 & -0.6 & $(114)$ \\
\hline 01463850 & Increase & 0.004 & 2.9 & 2.5 & $(117)$ \\
\hline 01464020 & Increase & 0.006 & 5.4 & 2.5 & $(215)$ \\
\hline \multicolumn{6}{|c|}{ Lower Delaware River Basin } \\
\hline 01411466 & -- & 0.859 & 0.0 & 0.1 & $(46)$ \\
\hline 01411500 & -- & 0.056 & 1.6 & 2.2 & (70) \\
\hline 01411955 & -- & 0.978 & 0.1 & 0.4 & $(25)$ \\
\hline 01412800 & -- & 0.133 & 1.1 & 0.9 & $(132)$ \\
\hline 01464504 & Increase & 0.050 & 2.1 & 1.8 & $(115)$ \\
\hline 01464515 & -- & 0.111 & 1.1 & 0.9 & (119) \\
\hline 01465893 & -- & 0.154 & 1.2 & 1.8 & (67) \\
\hline 01466500 & -- & 0.650 & 0.1 & 0.5 & (27) \\
\hline 01467005 & -- & 0.106 & -0.6 & -0.7 & (87) \\
\hline 01467150 & Increase & 0.006 & 4.9 & 3.3 & (149) \\
\hline 01467359 & Increase & 0.015 & 2.4 & 2.1 & $(112)$ \\
\hline 01477120 & Increase & 0.016 & 1.4 & 1.0 & (137) \\
\hline 01482500 & Increase & 0.008 & 1.5 & 0.9 & $(160)$ \\
\hline
\end{tabular}


Table 10. Summary statistics for total phosphorus at water-quality stations on New Jersey streams, water years 1998-2007.

[n.a., not applicable; <, less than; E, estimated]

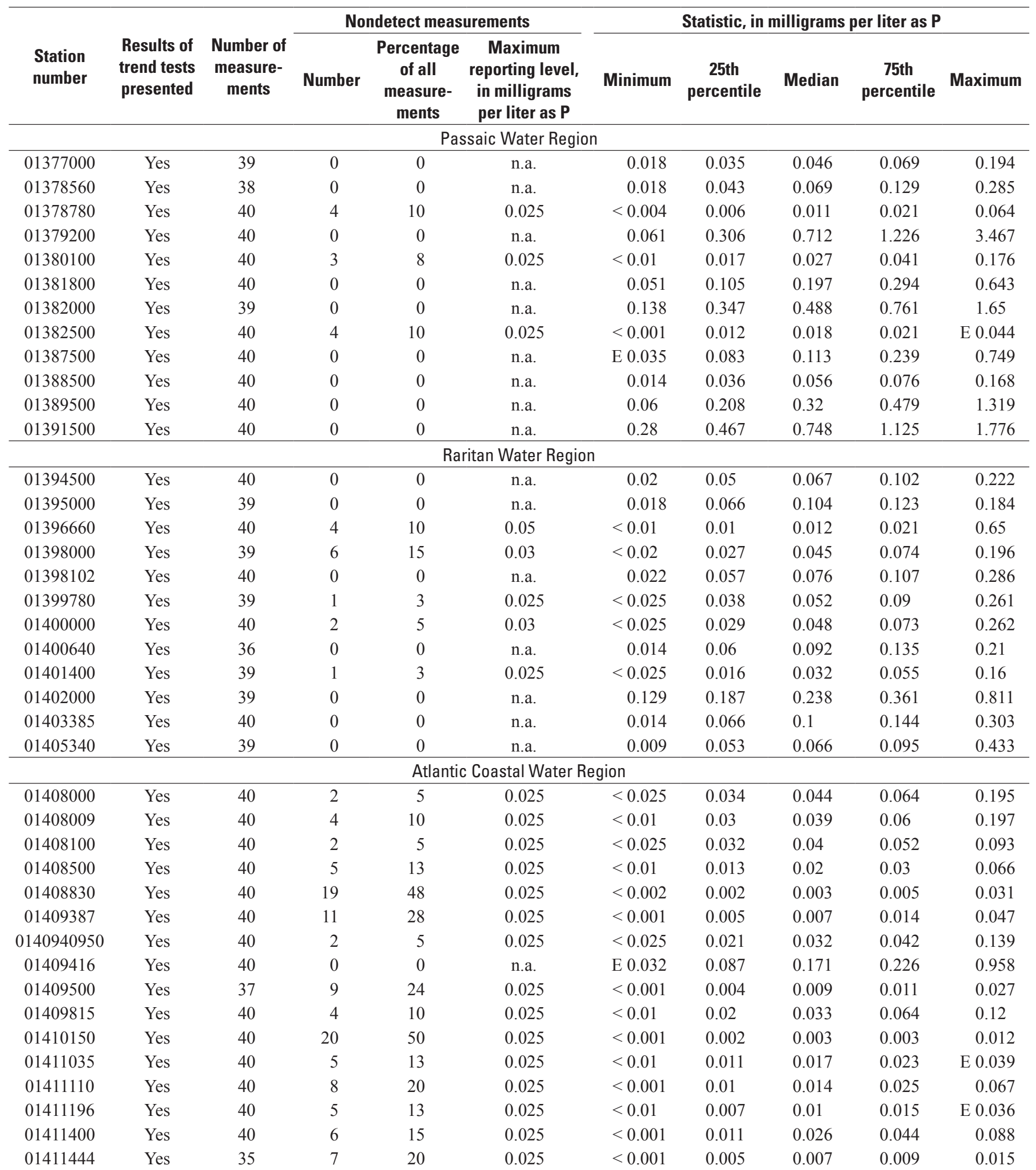


Table 10. Summary statistics for total phosphorus at water-quality stations on New Jersey streams, water years 1998-2007.-Continued

[n.a., not applicable; <, less than; E, estimated]

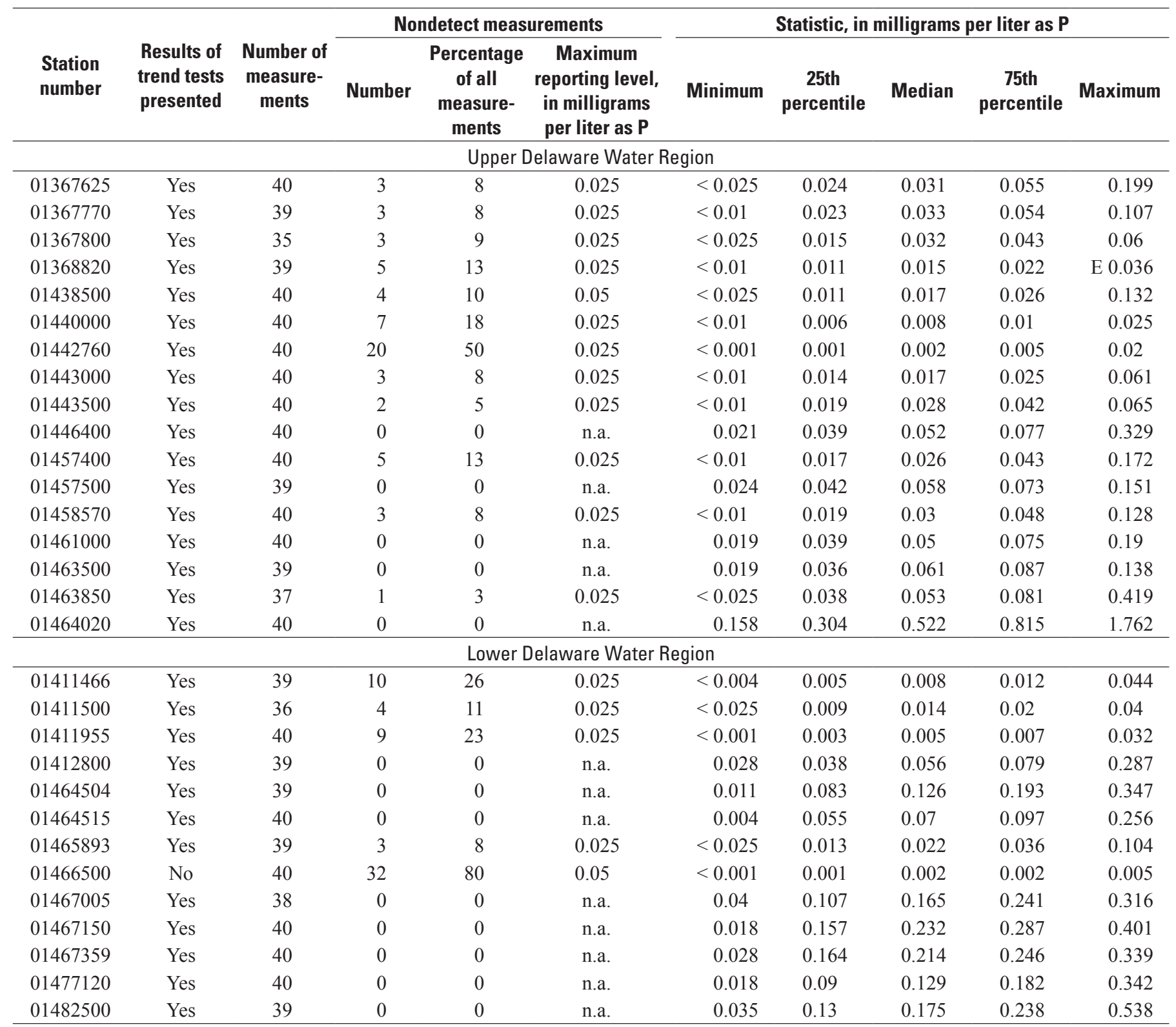


Table 11. Results of trend tests on flow-adjusted concentrations of total phosphorus at water-quality stations on New Jersey streams, water years 1998-2007.

[--, no trend in the flow-adjusted concentrations of total phosphorus during the period of study was identified at a 0.05 level of significance ; Decrease, total phosphorus decreased during the period of study; Increase, total phosphorus increased during the period of study; n.d., not determined]

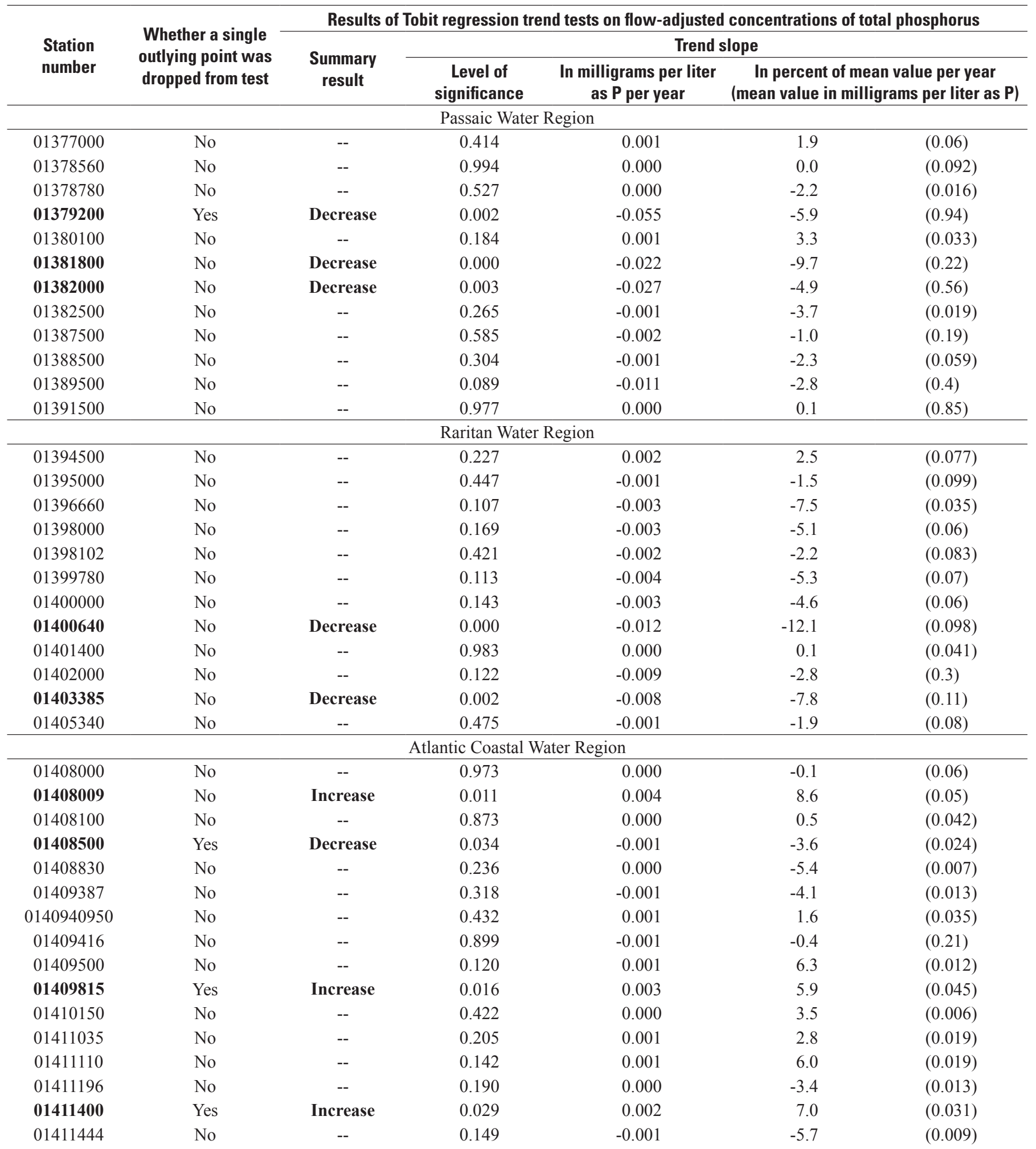


Table 11. Results of trend tests on flow-adjusted concentrations of total phosphorus at water-quality stations on New Jersey streams, water years 1998-2007.-Continued

[--, no trend in the flow-adjusted concentrations of total phosphorus during the period of study was identified at a 0.05 level of significance ; Decrease, total phosphorus decreased during the period of study; Increase, total phosphorus increased during the period of study; n.d., not determined]

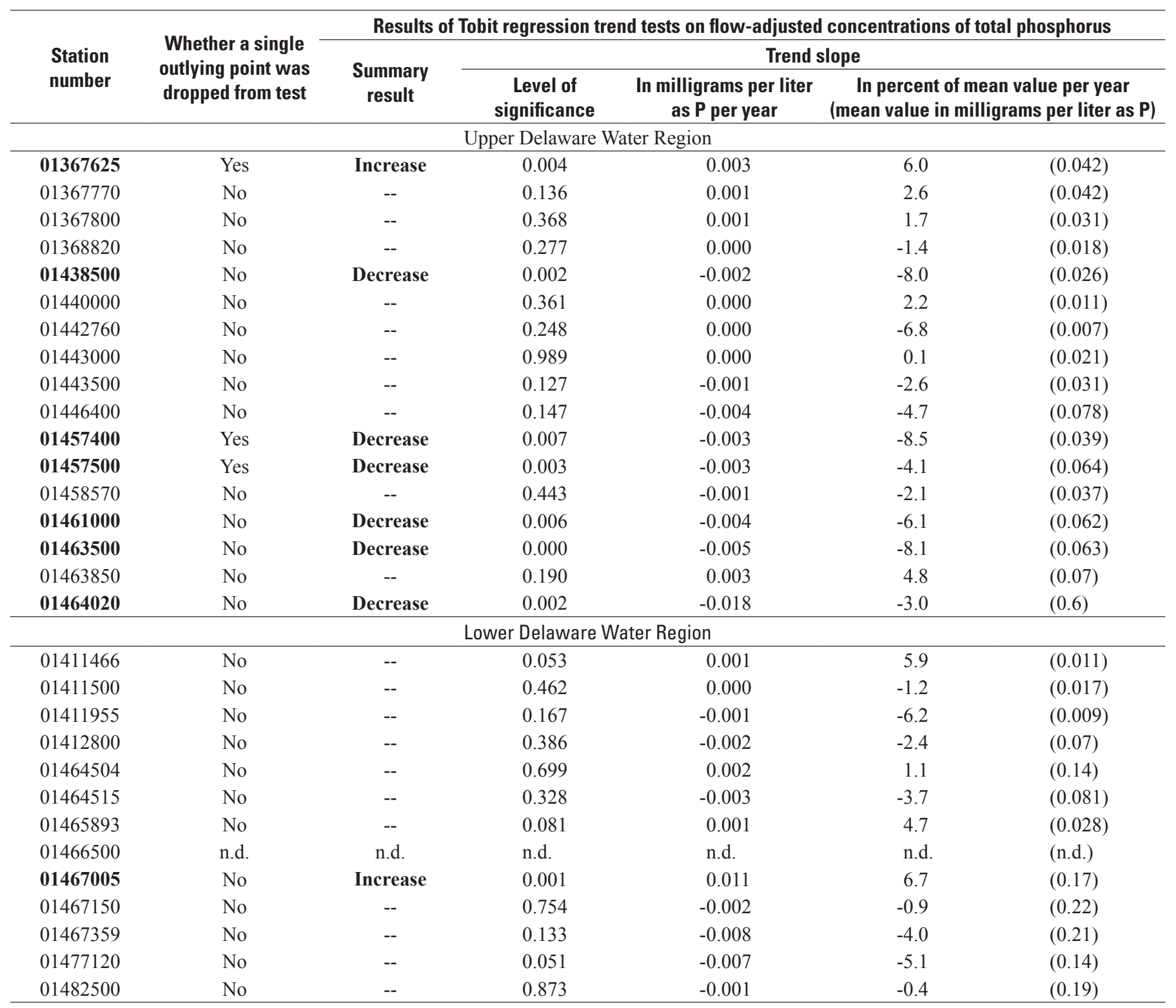


Table 12. Summary statistics for total organic nitrogen plus ammonia at water-quality stations on New Jersey streams, water years 1998-2007.

[n.a., not applicable; <, less than; ]

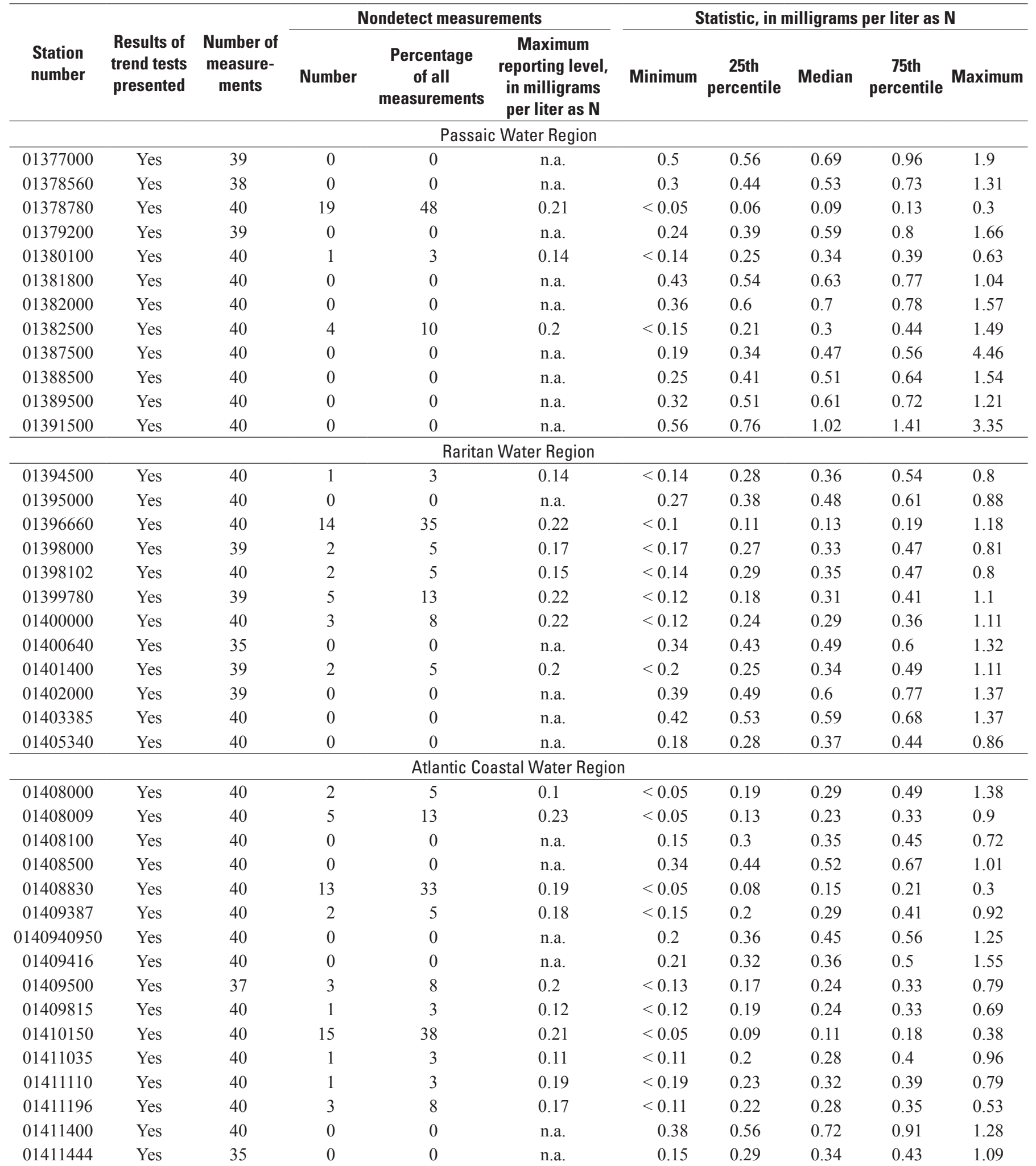


Table 12. Summary statistics for total organic nitrogen plus ammonia at water-quality stations on New Jersey streams, water years 1998-2007.-Continued

[n.a., not applicable; <, less than; ]

\begin{tabular}{|c|c|c|c|c|c|c|c|c|c|c|}
\hline \multirow[b]{2}{*}{$\begin{array}{l}\text { Station } \\
\text { number }\end{array}$} & \multirow[b]{2}{*}{$\begin{array}{l}\text { Results of } \\
\text { trend tests } \\
\text { presented }\end{array}$} & \multirow[b]{2}{*}{$\begin{array}{c}\text { Number of } \\
\text { measure- } \\
\text { ments }\end{array}$} & \multicolumn{3}{|c|}{ Nondetect measurements } & \multicolumn{5}{|c|}{ Statistic, in milligrams per liter as $\mathbf{N}$} \\
\hline & & & Number & $\begin{array}{c}\text { Percentage } \\
\text { of all } \\
\text { measurements }\end{array}$ & $\begin{array}{c}\text { Maximum } \\
\text { reporting level, } \\
\text { in milligrams } \\
\text { per liter as } \mathrm{N}\end{array}$ & Minimum & $\begin{array}{c}\text { 25th } \\
\text { percentile }\end{array}$ & Median & $\begin{array}{c}\text { 75th } \\
\text { percentile }\end{array}$ & Maximum \\
\hline \multicolumn{11}{|c|}{ Upper Delaware Water Region } \\
\hline 01367625 & Yes & 40 & 0 & 0 & n.a. & 0.12 & 0.3 & 0.37 & 0.46 & 1.39 \\
\hline 01368820 & Yes & 39 & 0 & 0 & n.a. & 0.18 & 0.26 & 0.35 & 0.39 & 0.49 \\
\hline 01438500 & Yes & 40 & 7 & 18 & 0.2 & $<0.12$ & 0.15 & 0.22 & 0.26 & 0.94 \\
\hline 01440000 & Yes & 40 & 17 & 43 & 0.21 & $<0.05$ & 0.08 & 0.13 & 0.19 & 0.32 \\
\hline 01442760 & No & 40 & 27 & 68 & 0.12 & $<0.04$ & 0.04 & 0.04 & 0.07 & 0.72 \\
\hline 01443000 & Yes & 40 & 6 & 15 & 0.19 & $<0.12$ & 0.15 & 0.19 & 0.26 & 0.63 \\
\hline 01457500 & Yes & 40 & 2 & 5 & 0.27 & $<0.13$ & 0.2 & 0.27 & 0.31 & 0.78 \\
\hline 01458570 & Yes & 40 & 16 & 40 & 0.22 & $<0.05$ & 0.1 & 0.15 & 0.23 & 0.52 \\
\hline 01461000 & Yes & 40 & 4 & 10 & 0.22 & $<0.12$ & 0.23 & 0.29 & 0.37 & 0.64 \\
\hline 01463500 & Yes & 35 & 0 & 0 & n.a. & 0.16 & 0.24 & 0.28 & 0.41 & 0.95 \\
\hline 01463850 & Yes & 40 & 0 & 0 & n.a. & 0.26 & 0.46 & 0.6 & 0.81 & 1.61 \\
\hline 01464020 & Yes & 40 & 0 & 0 & n.a. & 0.46 & 0.6 & 0.71 & 0.83 & 1.08 \\
\hline \multicolumn{11}{|c|}{ Lower Delaware Water Region } \\
\hline 01411466 & Yes & 39 & 1 & 3 & 0.17 & $<0.17$ & 0.26 & 0.32 & 0.46 & 0.87 \\
\hline 01411500 & Yes & 36 & 0 & 0 & n.a. & 0.2 & 0.3 & 0.39 & 0.56 & 1.06 \\
\hline 01411955 & Yes & 40 & 13 & 33 & 0.2 & $<0.09$ & 0.11 & 0.16 & 0.22 & 0.45 \\
\hline 01412800 & Yes & 40 & 0 & 0 & n.a. & 0.26 & 0.37 & 0.48 & 0.56 & 1.61 \\
\hline 01467359 & Yes & 40 & 0 & 0 & n.a. & 0.25 & 0.41 & 0.46 & 0.56 & 0.7 \\
\hline 01477120 & Yes & 40 & 0 & 0 & n.a. & 0.29 & 0.44 & 0.58 & 0.78 & 2.62 \\
\hline 01482500 & Yes & 40 & 0 & 0 & n.a. & 0.69 & 1.07 & 1.25 & 1.49 & 2.68 \\
\hline
\end{tabular}


Table 13. Results of trend tests on flow-adjusted concentrations of total organic nitrogen plus ammonia at water-quality stations on New Jersey streams, water years 1998-2007.

[--, no trend in flow-adjusted concentrations of total organic nitrogen plus ammonia during the period of study was identified at a 0.05 level of significance; Decrease, total organic nitrogen plus ammonia decreased during the period of study; Increase, total organic nitrogen plus ammonia increased during the period of study; n.d., not determined]

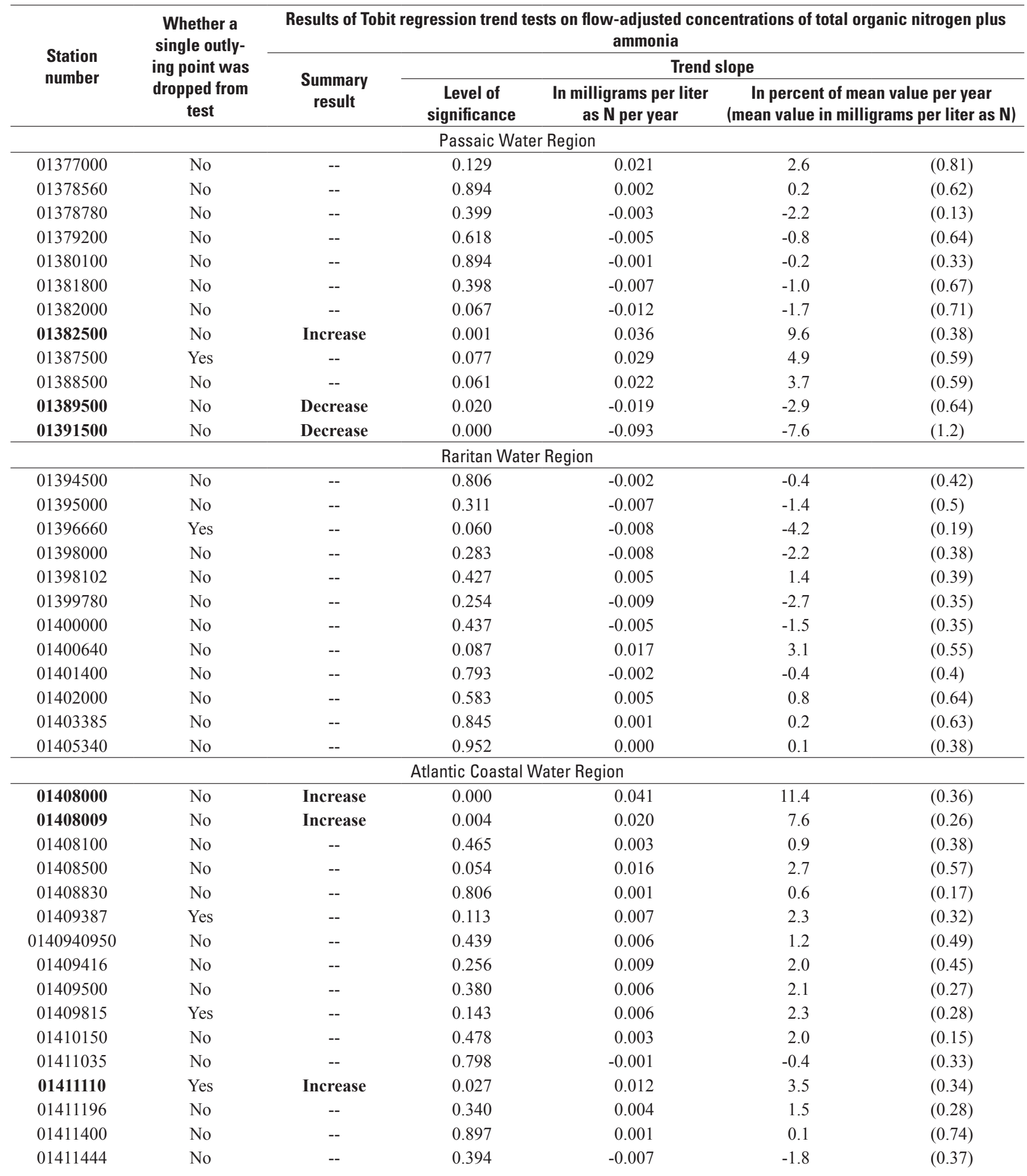


Table 13. Results of trend tests on flow-adjusted concentrations of total organic nitrogen plus ammonia at water-quality stations on New Jersey streams, water years 1998-2007.-Continued

[--, no trend in flow-adjusted concentrations of total organic nitrogen plus ammonia during the period of study was identified at a 0.05 level of significance; Decrease, total organic nitrogen plus ammonia decreased during the period of study; Increase, total organic nitrogen plus ammonia increased during the period of study; n.d., not determined]

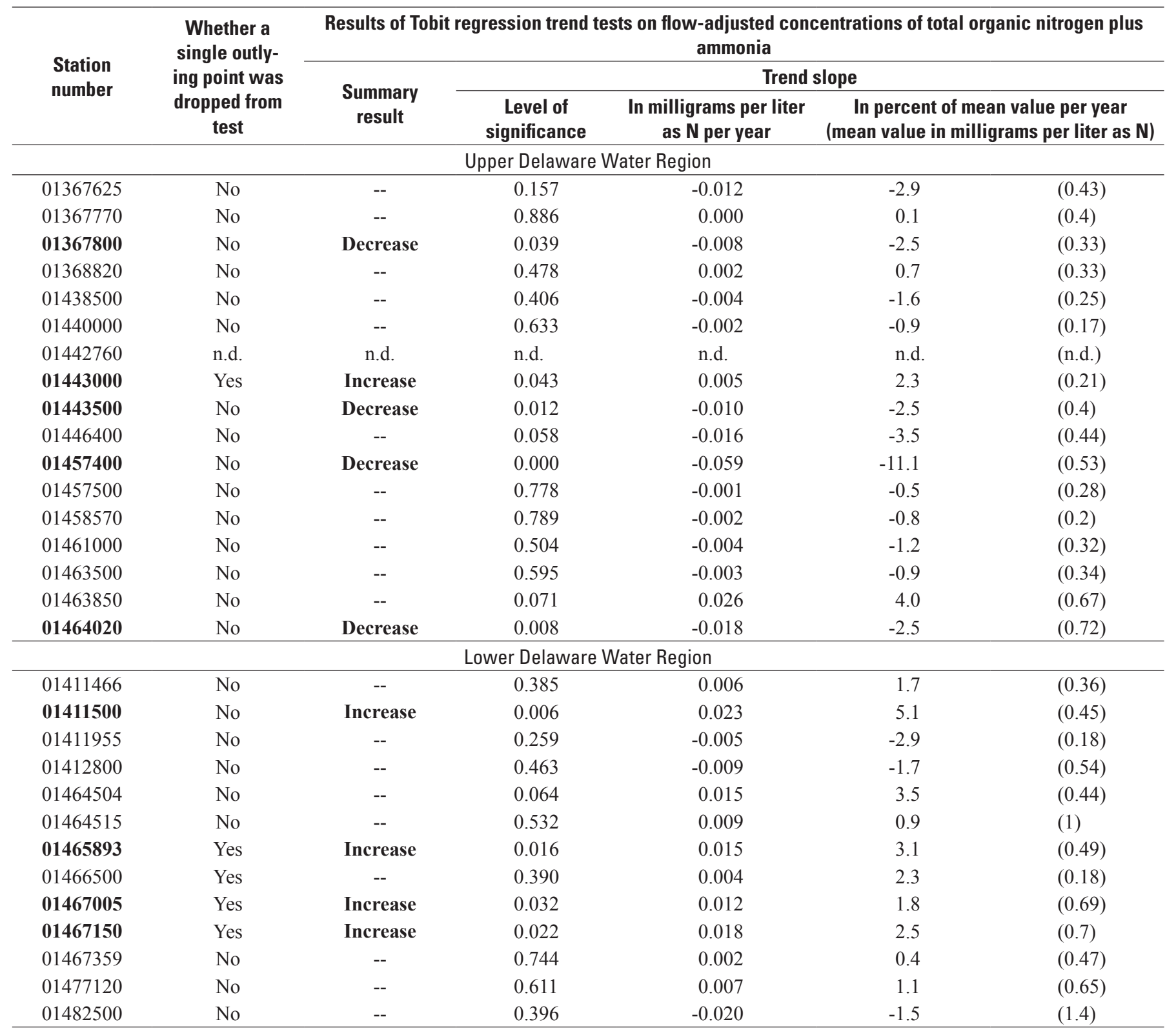


Table 14. Summary statistics for dissolved nitrate plus nitrite at water-quality stations on New Jersey streams, water years 1998-2007.

[n.a., not applicable; <, less than; E, estimated; n.d., not determined]

\begin{tabular}{|c|c|c|c|c|c|c|c|c|c|c|}
\hline \multirow[b]{2}{*}{$\begin{array}{l}\text { Station } \\
\text { number }\end{array}$} & \multirow[b]{2}{*}{$\begin{array}{c}\text { Results of } \\
\text { trend tests } \\
\text { presented }\end{array}$} & \multirow[b]{2}{*}{$\begin{array}{c}\text { Number } \\
\text { of mea- } \\
\text { surements }\end{array}$} & \multicolumn{3}{|c|}{ Nondetect measurements } & \multicolumn{5}{|c|}{ Statistic,in milligrams per liter as $\mathbf{N}$} \\
\hline & & & Number & $\begin{array}{c}\text { Percentage } \\
\text { of all } \\
\text { measurements }\end{array}$ & $\begin{array}{c}\text { Maximum } \\
\text { reporting level, } \\
\text { in milligrams } \\
\text { per liter as } \mathbf{N}\end{array}$ & Minimum & $\begin{array}{c}\text { 25th } \\
\text { percentile }\end{array}$ & Median & $\begin{array}{c}\text { 75th } \\
\text { percentile }\end{array}$ & Maximum \\
\hline \multicolumn{11}{|c|}{ Passaic Water Region } \\
\hline 01377000 & Yes & 39 & 0 & 0 & n.a. & 0.11 & 0.32 & 0.42 & 0.6 & 1.27 \\
\hline 01379200 & Yes & 39 & 0 & 0 & n.a. & 1 & 1.7 & 2.76 & 4.78 & 13.14 \\
\hline 01380100 & Yes & 40 & 1 & 3 & 0.03 & $<0.03$ & 0.1 & 0.16 & 0.23 & 0.36 \\
\hline 01381800 & Yes & 40 & 0 & 0 & n.a. & 0.19 & 1.17 & 1.94 & 2.59 & 5.03 \\
\hline 01382000 & Yes & 39 & 0 & 0 & n.a. & 0.41 & 1.48 & 2.44 & 3.65 & 6.62 \\
\hline 01382500 & Yes & 40 & 0 & 0 & n.a. & 0.06 & 0.11 & 0.18 & 0.29 & 0.67 \\
\hline 01391500 & Yes & 40 & 0 & 0 & n.a. & 1.4 & 4.07 & 5.06 & 6.34 & 9.28 \\
\hline \multicolumn{11}{|c|}{ Raritan Water Region } \\
\hline 01394500 & Yes & 40 & 0 & 0 & n.a. & 0.51 & 1.16 & 1.28 & 1.43 & 2.01 \\
\hline 01395000 & Yes & 40 & 0 & 0 & n.a. & 0.39 & 0.75 & 1.08 & 1.22 & 1.61 \\
\hline 01396660 & Yes & 40 & 0 & 0 & n.a. & 0.47 & 0.66 & 0.82 & 0.95 & 1.42 \\
\hline 01398000 & Yes & 38 & 3 & 8 & 0.05 & $<0.02$ & 0.66 & 1.21 & 1.56 & 2.76 \\
\hline 01398102 & Yes & 38 & 0 & 0 & n.a. & 0.39 & 1.16 & 1.4 & 1.64 & 2.37 \\
\hline 01399780 & Yes & 39 & 0 & 0 & n.a. & 0.06 & 0.71 & 0.85 & 1.11 & 1.89 \\
\hline 01400000 & Yes & 40 & 0 & 0 & n.a. & 0.21 & 0.73 & 0.95 & 1.1 & 1.35 \\
\hline 01400640 & Yes & 36 & 0 & 0 & n.a. & 0.95 & 3.12 & 3.88 & 4.73 & 8.08 \\
\hline 01408100 & Yes & 40 & 0 & 0 & n.a. & 0.14 & 0.36 & 0.48 & 0.65 & 1.19 \\
\hline 01408500 & Yes & 39 & 0 & 0 & n.a. & 0.11 & 0.42 & 0.59 & 0.72 & 1.19 \\
\hline 01408830 & No & 40 & 33 & 83 & 0.05 & $<0.01$ & n.d. & n.d. & n.d. & 0.13 \\
\hline 01409387 & Yes & 40 & 3 & 8 & 0.05 & $<0.02$ & 0.05 & 0.08 & 0.09 & 0.27 \\
\hline 0140940950 & Yes & 39 & 13 & 33 & 0.05 & $<0.01$ & 0.02 & 0.15 & 0.29 & 1.13 \\
\hline 01409416 & Yes & 40 & 0 & 0 & n.a. & 0.6 & 0.82 & 1.1 & 2 & 2.66 \\
\hline 01409500 & Yes & 37 & 2 & 5 & 0.05 & $<0.05$ & 0.08 & 0.11 & 0.22 & 0.56 \\
\hline 01409815 & No & 40 & 35 & 88 & 0.05 & $<0.01$ & n.d. & n.d. & n.d. & 0.07 \\
\hline 01410150 & No & 40 & 34 & 85 & 0.05 & $<0.01$ & n.d. & n.d. & n.d. & 0.28 \\
\hline 01411035 & Yes & 40 & 0 & 0 & n.a. & 0.37 & 0.65 & 0.96 & 1.42 & 2.04 \\
\hline 01411110 & Yes & 40 & 0 & 0 & n.a. & 0.06 & 0.38 & 0.47 & 0.56 & 0.74 \\
\hline 01411196 & Yes & 40 & 0 & 0 & n.a. & 0.2 & 0.41 & 0.51 & 0.64 & E 0.85 \\
\hline 01411400 & Yes & 40 & 15 & 38 & 0.05 & $<0.02$ & n.d. & 0.05 & 0.14 & 0.43 \\
\hline 01411444 & Yes & 35 & 21 & 60 & 0.05 & $<0.01$ & 0.01 & 0.02 & 0.05 & 0.3 \\
\hline
\end{tabular}


Table 14. Summary statistics for dissolved nitrate plus nitrite at water-quality stations on New Jersey streams, water years 1998-2007.-Continued

[n.a., not applicable; <, less than; E, estimated; n.d., not determined]

\begin{tabular}{|c|c|c|c|c|c|c|c|c|c|c|}
\hline \multirow[b]{2}{*}{$\begin{array}{l}\text { Station } \\
\text { number }\end{array}$} & \multirow[b]{2}{*}{$\begin{array}{c}\text { Results of } \\
\text { trend tests } \\
\text { presented }\end{array}$} & \multirow[b]{2}{*}{$\begin{array}{c}\text { Number } \\
\text { of mea- } \\
\text { surements }\end{array}$} & \multicolumn{3}{|c|}{ Nondetect measurements } & \multicolumn{5}{|c|}{ Statistic,in milligrams per liter as $\mathbf{N}$} \\
\hline & & & Number & $\begin{array}{c}\text { Percentage } \\
\text { of all } \\
\text { measurements }\end{array}$ & $\begin{array}{c}\text { Maximum } \\
\text { reporting level, } \\
\text { in milligrams } \\
\text { per liter as } \mathbf{N}\end{array}$ & Minimum & $\begin{array}{c}\text { 25th } \\
\text { percentile }\end{array}$ & Median & $\begin{array}{c}\text { 75th } \\
\text { percentile }\end{array}$ & Maximum \\
\hline \multicolumn{11}{|c|}{ Upper Delaware Water Region } \\
\hline 01367625 & Yes & 40 & 0 & 0 & n.a. & 0.16 & 0.37 & 0.5 & 0.66 & 1.4 \\
\hline 01368820 & Yes & 39 & 14 & 36 & 0.05 & $<0.01$ & 0.02 & 0.03 & 0.09 & 0.19 \\
\hline 01438500 & Yes & 40 & 0 & 0 & n.a. & E 0.06 & 0.16 & 0.21 & 0.29 & 0.43 \\
\hline 01440000 & Yes & 40 & 12 & 30 & 0.05 & $<0.02$ & n.d. & 0.07 & 0.12 & 0.25 \\
\hline 01442760 & Yes & 40 & 20 & 50 & 0.05 & $<0.01$ & 0.01 & 0.02 & 0.09 & 1.1 \\
\hline 01443000 & Yes & 40 & 1 & 3 & 0.03 & $<0.03$ & 0.13 & 0.18 & 0.26 & 0.46 \\
\hline 01457500 & Yes & 40 & 0 & 0 & n.a. & 0.48 & 0.82 & 0.96 & 1.14 & 1.6 \\
\hline 01458570 & Yes & 40 & 0 & 0 & n.a. & 0.24 & 1.37 & 1.92 & 2.4 & 3.09 \\
\hline 01461000 & Yes & 38 & 0 & 0 & n.a. & 0.56 & 0.8 & 0.93 & 1.08 & 1.4 \\
\hline 01463500 & Yes & 39 & 0 & 0 & n.a. & 0.47 & 0.66 & 0.84 & 0.98 & 1.3 \\
\hline 01463850 & Yes & 40 & 0 & 0 & n.a. & Е 0.03 & 0.79 & 1.06 & 1.43 & 3.46 \\
\hline 01464020 & Yes & 40 & 0 & 0 & n.a. & 1.23 & 2.82 & 4.06 & 5.78 & 9.77 \\
\hline \multicolumn{11}{|c|}{ Lower Delaware Water Region } \\
\hline 01411466 & Yes & 39 & 0 & 0 & n.a. & 0.15 & 0.35 & 0.52 & 0.61 & 0.72 \\
\hline 01411500 & Yes & 34 & 0 & 0 & n.a. & 0.35 & 1.45 & 1.67 & 1.86 & 2.45 \\
\hline 01411955 & Yes & 40 & 1 & 3 & 0.01 & $<0.01$ & 0.08 & 0.11 & 0.13 & 0.23 \\
\hline 01467359 & Yes & 40 & 0 & 0 & n.a. & 0.26 & 0.42 & 0.5 & 0.67 & 1.13 \\
\hline 01477120 & Yes & 40 & 0 & 0 & n.a. & 0.59 & 1.01 & 1.22 & 1.62 & 3.28 \\
\hline 01482500 & Yes & 40 & 1 & 3 & 0.03 & $<0.03$ & 0.53 & 1.97 & 2.76 & 5.45 \\
\hline
\end{tabular}


Table 15. Results of trend tests on flow-adjusted concentrations of dissolved nitrate plus nitrite at water-quality stations on New Jersey streams, water years 1998-2007.

[ --, no trend in flow-adjusted concentrations of dissolved nitrate plus nitrite during the period of study was identified at a 0.05 level of significance; Decrease, dissolved nitrate plus nitrite decreased during the period of study; Increase, dissolved nitrate plus nitrite increased during the period of study; n.d., not determined]

\begin{tabular}{|c|c|c|c|c|c|c|}
\hline \multirow{3}{*}{$\begin{array}{l}\text { Station } \\
\text { number }\end{array}$} & \multirow{3}{*}{$\begin{array}{l}\text { Whether a single } \\
\text { outlying point was } \\
\text { dropped from test }\end{array}$} & \multicolumn{5}{|c|}{ Results of Tobit regression trend tests on flow-adjusted concentrations of dissolved nitrate plus nitrite } \\
\hline & & \multirow[b]{2}{*}{$\begin{array}{l}\text { Summary } \\
\text { result }\end{array}$} & \multicolumn{4}{|c|}{ Trend slope } \\
\hline & & & $\begin{array}{c}\text { Level of } \\
\text { significance }\end{array}$ & $\begin{array}{c}\text { In milligrams per liter } \\
\text { as } \mathbf{N} \text { per year }\end{array}$ & $\begin{array}{c}\text { In percent } 0 \\
\text { value in }\end{array}$ & $\begin{array}{l}\text { year (mean } \\
\text { iter as } \mathbf{N} \text { ) }\end{array}$ \\
\hline \multicolumn{7}{|c|}{ Passaic Water Region } \\
\hline 01377000 & No & -- & 0.207 & 0.010 & 2.1 & $(0.47)$ \\
\hline 01378560 & No & -- & 0.715 & 0.013 & 1.2 & $(1.1)$ \\
\hline 01380100 & Yes & Increase & 0.043 & 0.009 & 5.2 & $(0.18)$ \\
\hline 01381800 & No & -- & 0.496 & -0.020 & -1.0 & $(1.9)$ \\
\hline 01382000 & No & -- & 0.101 & -0.063 & -2.4 & $(2.6)$ \\
\hline 01382500 & No & -- & 0.485 & -0.004 & -1.7 & $(0.22)$ \\
\hline 01387500 & No & -- & 0.951 & 0.001 & 0.1 & $(1.6)$ \\
\hline \multicolumn{7}{|c|}{ Raritan Water Region } \\
\hline 01394500 & No & -- & 0.285 & -0.018 & -1.4 & $(1.3)$ \\
\hline 01395000 & Yes & -- & 0.131 & 0.028 & 2.7 & (1) \\
\hline 01396660 & No & Increase & 0.035 & 0.021 & 2.5 & $(0.84)$ \\
\hline 01398000 & No & -- & 0.768 & -0.016 & -1.4 & $(1.1)$ \\
\hline 01398102 & No & -- & 0.913 & -0.003 & -0.2 & $(1.4)$ \\
\hline 01399780 & No & -- & 0.140 & 0.044 & 5.0 & $(0.89)$ \\
\hline 01400000 & No & Increase & 0.003 & 0.053 & 5.9 & $(0.91)$ \\
\hline 01400640 & No & -- & 0.050 & 0.121 & 3.0 & (4) \\
\hline 01401400 & No & -- & 0.523 & 0.020 & 0.7 & $(2.7)$ \\
\hline 01408500 & No & Increase & 0.010 & 0.018 & 3.1 & $(0.6)$ \\
\hline 01408830 & n.d. & n.d. & n.d. & n.d. & n.d. & (n.d.) \\
\hline 01409387 & No & -- & 0.231 & 0.003 & 3.1 & $(0.087)$ \\
\hline 0140940950 & No & -- & 0.202 & 0.017 & 6.6 & $(0.25)$ \\
\hline 01409416 & No & Increase & 0.015 & 0.059 & 4.3 & $(1.4)$ \\
\hline 01409500 & No & Increase & 0.013 & 0.011 & 6.9 & $(0.16)$ \\
\hline 01409815 & n.d. & n.d. & n.d. & n.d. & n.d. & (n.d.) \\
\hline 01410150 & n.d. & n.d. & n.d. & n.d. & n.d. & (n.d.) \\
\hline 01411035 & No & Decrease & 0.001 & -0.033 & -3.2 & (1) \\
\hline 01411110 & Yes & Increase & 0.000 & 0.020 & 4.3 & $(0.48)$ \\
\hline 01411196 & No & Increase & 0.019 & 0.012 & 2.4 & $(0.51)$ \\
\hline 01411400 & No & -- & 0.220 & -0.006 & -6.7 & $(0.096)$ \\
\hline 01411444 & No & -- & 0.627 & 0.002 & 2.8 & $(0.059)$ \\
\hline
\end{tabular}


Table 15. Results of trend tests on flow-adjusted concentrations of dissolved nitrate plus nitrite at water-quality stations on New Jersey streams, water years 1998-2007.-Continued

[ --, no trend in flow-adjusted concentrations of dissolved nitrate plus nitrite during the period of study was identified at a 0.05 level of significance; Decrease, dissolved nitrate plus nitrite decreased during the period of study; Increase, dissolved nitrate plus nitrite increased during the period of study; n.d., not determined]

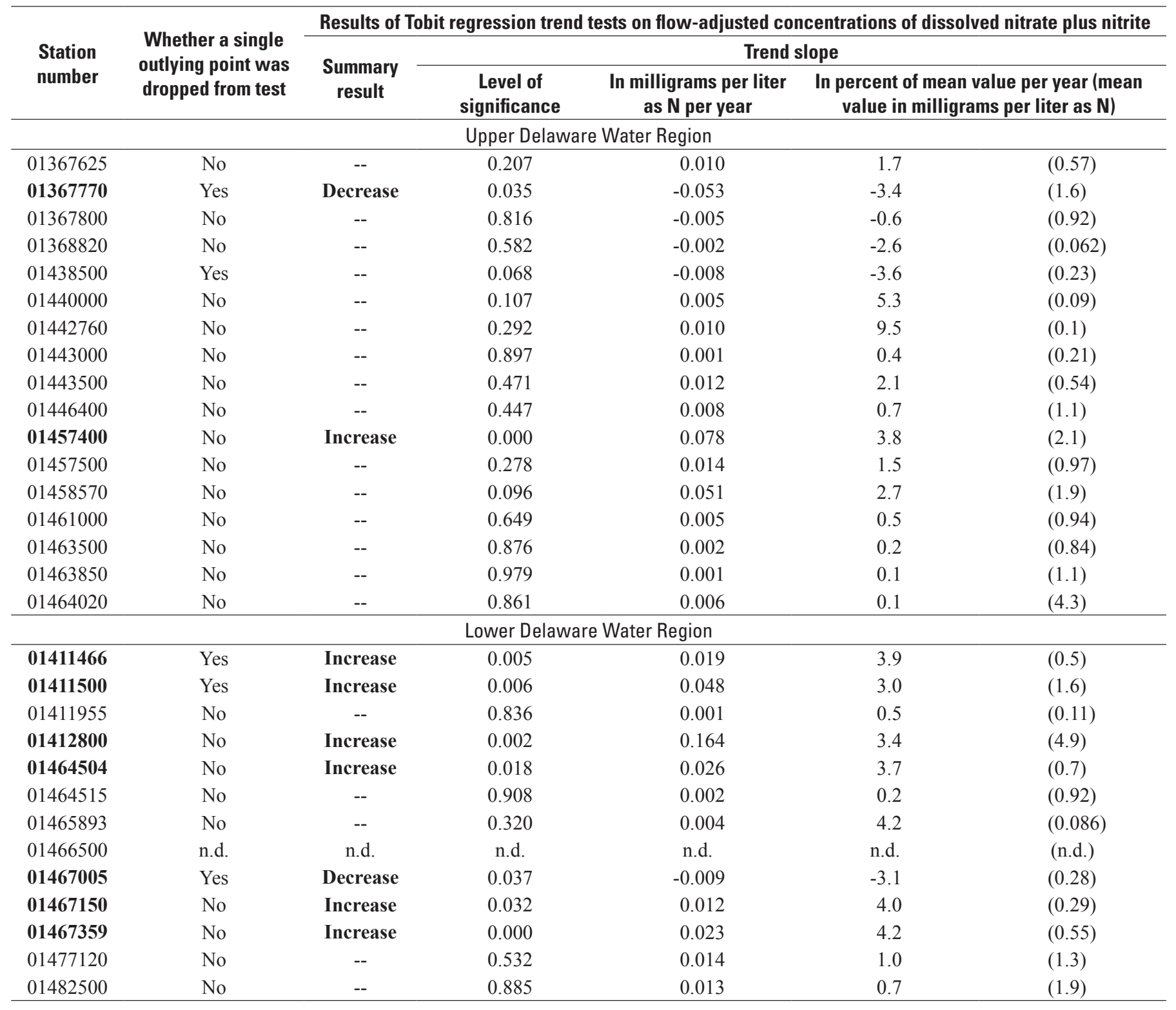


For additional information, write to: Director

U.S. Geological Survey

New Jersey Water Science Center

810 Bear Tavern Road, Suite 206

West Trenton, NJ 08628

or visit our Web site at:

http://nj.usgs.gov/

Document prepared by the West Trenton Publishing Service Center 
